\title{
Carbon Capture and Sequestration (via Enhanced Oil Recovery) from a Hydrogen Production Facility in an Oil Refinery
}

\author{
Prepared for: \\ U.S. Department of Energy \\ National Energy Technology Laboratory
}

Type of Report (Final Scientific/Technical or Topical): Final Scientific/Technical Reporting Period Start Date: November 16, 2009

Reporting Period End Date: June 16, 2010

Principal Author(s): Stewart Mehlman

Date Report was issued: June 2010

DOE Award Number: DE-FE-0001871

\section{Prepared by:}

Praxair, Inc., 39 Old Ridgebury Road, Danbury, CT 06810

Denbury Onshore LLC, 5100 Tennyson Parkway, \#1200, Plano, TX 75024

Gulf Coast Carbon Center, Bureau of Economic Geology, The University of Texas at Austin, University Station, Box X, Austin, Texas 78713-8924

\section{Disclaimer:}

"This report was prepared as an account of work sponsored by an agency of the United States Government. Neither the United States Government nor any agency thereof, nor any of their employees, makes any warranty, express or implied, or assumes any legal liability or responsibility for the accuracy, completeness, or usefulness of any information, apparatus, product, or process disclosed, or represents that its use would not infringe privately owned rights. Reference herein to any specific commercial product, process, or service by trade name, trademark, manufacturer, or otherwise does not necessarily constitute or imply its endorsement, recommendation, or favoring by the United States Government or any agency thereof. The views and opinions of authors expressed herein do not necessarily state or reflect those of the United States Government or any agency thereof." 


\section{Abstract}

The project proposed a commercial demonstration of advanced technologies that would capture and sequester $\mathrm{CO}_{2}$ emissions from an existing hydrogen production facility in an oil refinery into underground formations in combination with Enhanced Oil Recovery (EOR). The project is led by Praxair, Inc., with other project participants: BP Products North America Inc., Denbury Onshore, LLC (Denbury), and Gulf Coast Carbon Center (GCCC) at the Bureau of Economic Geology of The University of Texas at Austin. The project is located at the BP Refinery at Texas City, Texas. Praxair owns and operates a large hydrogen production facility within the refinery. As part of the project, Praxair would construct a $\mathrm{CO}_{2}$ capture and compression facility. The project aimed at demonstrating a novel vacuum pressure swing adsorption (VPSA) based technology to remove $\mathrm{CO}_{2}$ from the Steam Methane Reformers (SMR) process gas. The captured $\mathrm{CO}_{2}$ would be purified using refrigerated partial condensation separation (i.e., cold box). Denbury would purchase the $\mathrm{CO}_{2}$ from the project and inject the $\mathrm{CO}_{2}$ as part of its independent commercial EOR projects. The Gulf Coast Carbon Center at the Bureau of Economic Geology, a unit of University of Texas at Austin, would manage the research monitoring, verification and accounting (MVA) project for the sequestered $\mathrm{CO}_{2}$, in conjunction with Denbury. The sequestration and associated MVA activities would be carried out in the Hastings field at Brazoria County, TX. The project would exceed DOE's target of capturing one million tons of $\mathrm{CO}_{2}$ per year (MTPY) by 2015. Phase 1 of the project (Project Definition) is being completed. The key objective of Phase 1 is to define the project in sufficient detail to enable an economic decision with regard to proceeding with Phase 2.

This topical report summarizes the administrative, programmatic and technical accomplishments completed in Phase 1 of the project. It describes the work relative to project technical and design activities (associated with $\mathrm{CO}_{2}$ capture technologies and geologic sequestration MVA), and Environmental Information Volume.

Specific accomplishments of this Phase include:

1. Finalization of the Project Management Plan

2. Development of engineering designs in sufficient detail for defining project performance and costs

3. Preparation of Environmental Information Volume

4. Completion of Hazard Identification Studies

5. Completion of control cost estimates and preparation of business plan

During the Phase 1 detailed cost estimate, project costs increased substantially from the previous estimate. Furthermore, the detailed risk assessment identified integration risks associated with potentially impacting the steam methane reformer operation. While the Phase 1 work identified ways to mitigate these integration risks satisfactorily from an operational perspective, the associated costs and potential schedule impacts contributed to the decision not to proceed to Phase 2. We have concluded that the project costs and integration risks at Texas City are not commensurate with the potential benefits of the project at this time. 


\section{Table of Contents}

Section

Title

Page

Abstract

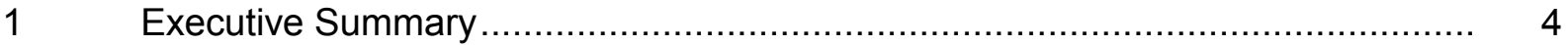

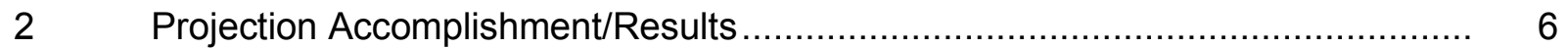

$2.0 \quad$ General Technical Description .............................................................. 6

$2.1 \quad$ Project Management...................................................................... 6

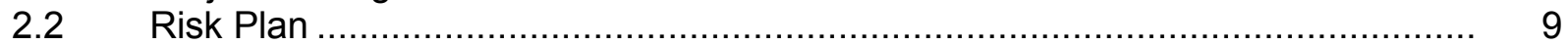

$2.3 \quad \mathrm{CO}_{2}$ Capture, Integration, and $\mathrm{CO}_{2}$ Compression ..................................... 10

$2.4 \quad \mathrm{CO}_{2}$ Transport, Delivery, Injection and Geologic Sequestration; MVA of

Stored $\mathrm{CO}_{2}$ (MVA) ……………............................................... 24

$3 \quad$ Environmental Impacts and Permits ..................................................... 25

3.1 National Environmental Policy Act (NEPA), Environmental Information Volume .. 25

3.2 Permits and Other Regulatory Authorizations ............................................... 30

$4 \quad$ Prospectus for Phase 2 Project............................................................. 34

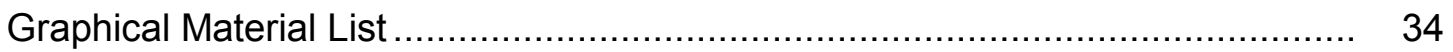

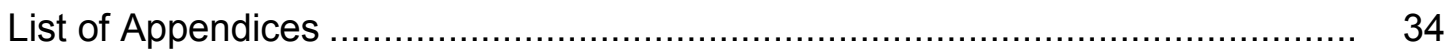

List of Acronyms and Abbreviations ........................................................... $\quad 34$

\section{List of Tables}

Table

Title

Page

$1 \quad$ Comparison of Impacts of Considered Alternatives.......................................... 26

$2 \quad \begin{aligned} & \text { Applicable Permits for the Proposed Action Praxair Texas City } \\ & \text { Carbon Capture, Transport, and Sequestration Project................................ } 31\end{aligned}$

List of Figures

Figure

Title

Page

$1 \quad$ Overall Block Flow Diagram for the Carbon Capture System (CCS) Project ........ 7

$2 \quad$ Novel Hybrid (VPSA and Cold Box) Process Flow Diagram............................. 11

$3 \quad$ Global Procurement and Material Management Group .................................. 18 


\section{Section 1: Executive Summary}

The project proposed a commercial demonstration of advanced technologies that capture and sequester $\mathrm{CO}_{2}$ emissions from an existing hydrogen production facility in an oil refinery into underground formations in combination with EOR. The project is led by Praxair, Inc., with other project participants: BP Products North America Inc., Denbury Onshore, LLC (Denbury), and Gulf Coast Carbon Center (GCCC). The project is located at the BP Refinery at Texas City, Texas, which is one of the largest refineries in the world. BP would provide land to the project and allow for interconnection to the necessary utility infrastructure. Praxair owns and operates a large hydrogen production facility within the refinery. As part of the project, Praxair would construct a $\mathrm{CO}_{2}$ capture and compression facility. The project's goal would be to demonstrate a novel VPSA based technology to remove $\mathrm{CO}_{2}$ from the SMR process gas. The captured $\mathrm{CO}_{2}$ would be purified using refrigerated partial condensation separation (i.e., cold box). Within the VPSA/Cold Box battery limits, the $\mathrm{CO}_{2}$ would be purified and compressed. The $\mathrm{CO}_{2}$ would be then transported via connector pipeline to the Green Pipeline owned by a Denbury affiliate that supplies $\mathrm{CO}_{2}$ to Denbury's EOR fields. The Green Pipeline supplies $\mathrm{CO}_{2}$ to several EOR fields and all the captured $\mathrm{CO}_{2}$ that enters the Green Pipeline would be sequestered at one of the EOR locations. For the purposes of conducting MVA activities, Denbury's Hastings field in Brazoria County, Texas was chosen. The project would provide an opportunity to build an efficient MVA program for a commercial setting.

This topical report summarizes the administrative, programmatic and technical accomplishments completed in Phase 1 of the project. It describes the work relative to project technical and design activities (associated with $\mathrm{CO}_{2}$ capture technologies, geologic sequestration MVA), and Environmental Information Volume (EIV). The key objective of Phase 1 is to define the project in sufficient detail to enable an economic decision with regard to proceeding with Phase 2. The design basis included not only the operation requirements for the demonstration period but also that for continued operation after the demonstration would be completed.

Specific accomplishments of Phase 1 include:

1. Finalization of the Project Management Plan (PMP)

2. Development of engineering designs in sufficient detail for defining project performance and costs

3. Preparation of Environmental Information Volume

4. Completion of Hazard Identification Studies

5. Completion of control cost estimates and preparation of business plan

The project would exceed the program objectives by advancing technologies that would capture and sequester $95 \%$ of $\mathrm{CO}_{2}$ from a treated stream (syngas) in a hydrogen production facility, with the feed stream comprising $16 \% \mathrm{CO}_{2}$ (by volume). At present, this $\mathrm{CO}_{2}$ is ultimately being emitted to the atmosphere as part of the combustion process that provides energy to hydrogen facility. The project's design normal operating capture and sequestration capacity of 1.01 million TPY of $\mathrm{CO}_{2}$ is an integral component of commercial operations and exceeds the program objectives.

The Industrial Carbon Capture System (ICCS) project consists of two parallel projects that would be executed concurrently. Praxair would be performing the integration, capture, purification and compression of the $\mathrm{CO}_{2}$ removed from the SMR syngas. Denbury would be responsible for arranging the transportation, and injection activities. Additionally, GCCC would 
be a third tier subcontractor under contract to Denbury to perform the research measurement, verification and monitoring project for the stored $\mathrm{CO}_{2}$.

The Project Team would perform all project management activities (i.e., planning, tracking, executing, controlling, and communicating) necessary to meet technical, cost, and schedule goals per the Cooperative Agreement. The technical, cost, and schedule information would be periodically updated and reported. The activities would include environmental permitting and compliance.

Praxair would employ current project management principles, including earned value management, to track completion of work, to keep activities on schedule, and to control costs to remain within the budget. The PMP would be updated for the overall schedule, cost, and integration for all the components that constitute the project. Additionally, the overall risk mitigation plan would be executed.

Equipment engineering and selection during the Phase 1 work followed a well defined work process. Based on process conditions, procurement quality equipment specifications were developed for all major equipment. These project specific specifications build on already existing standard specifications developed by Praxair based on operations and project execution experience. Representative conceptual construction drawings and specifications were developed to obtain contractor quotations and key quantities. Detailed task level engineering plans were used to obtain detailed engineering estimates for internal and external resources.

Based on the complex and first of a kind nature of the capture project, a Hazard Identification Study (HAZID) was conducted. A HAZID involves the identification of the possible hazards that may be present within new/first-of-a-kind processes, changes to existing processes, and upgrades/modifications to existing facilities. An overall project risk assessment was also conducted.

An EIV has been prepared to provide information regarding existing environmental conditions, potential environmental impacts, and mitigative measures associated with the development of a commercial demonstration of advanced technologies. The project would capture $\mathrm{CO}_{2}$ emissions from an existing hydrogen production facility which provides hydrogen to existing refinery and chemical customers and sequester in underground formations in combination with EOR.

As a result of the cost and risk analysis conducted during Phase 1, Praxair has decided not to pursue funding for Phase 2. We have concluded that the project costs and integration risks at Texas City are not commensurate with potential benefits of the project at this time. During the Phase 1 detailed cost estimate, project costs increased substantially from the previous estimate.

Furthermore, the detailed risk assessment identified integration risks associated with potentially impacting the steam methane reformer operation. The integration issues arise since we are removing $\mathrm{CO}_{2}$ from a process stream in the plant as opposed to a flue gas stream. While the Phase 1 work identified ways to mitigate these integration risks satisfactorily from an operational perspective, the associated costs and potential schedule impacts contributed to the decision not to proceed to Phase 2. 


\section{Section 2: Project Accomplishments/Results}

\subsection{General Technical Description}

Praxair's facility at Texas City includes two SMR plants (named HU-3 and HU-4), each processing natural gas as feeds and producing 100 Mscfd of hydrogen and high pressure steam.

Natural gas feed is heated and fed to a hydrotreater where any organic sulfur compounds are converted to $\mathrm{H}_{2} \mathrm{~S}$. Sulfur compounds are then removed by $\mathrm{ZnO}$ absorbent in a de-sulfurizer. The sulfur-free feed gas from the de-sulfurizer is mixed with process steam, heated, and fed to the reformer where the majority of hydrogen is produced. The overall reaction is endothermic, requiring heat supplied by the reformer burners. Most of the fuel requirement for the burners is met by tail gas from the Pressure Swing Adsorber (PSA) system. The rest is supplied by a small flow of supplemental natural gas fuel.

Gas exiting the reformer is cooled, fed to a shift reactor where additional hydrogen is produced, then further cooled against various warming process streams in order to achieve a high level of plant thermal efficiency. The cooled process gas is then sent to a PSA system where purification of the hydrogen product takes place. Impurities removed from the PSA feed gas, including methane, carbon monoxide, nitrogen, and most significantly carbon dioxide, exit the PSA system in the tailgas stream along with unrecovered hydrogen. The tailgas stream is fed to the reformer burners where combustion occurs, thereby supplying energy for the reforming reaction.

Heat, produced by combustion of air and fuel in the reformer burners, is partly transferred to the reformer tubes. Remaining heat from the hot flue gas is recovered in the subsequent Waste Heat Recovery (WHR) section. An Induced Draft (ID) fan is used to draw the combustion products out of the reformer firebox, through the WHR section, and discharge them to atmosphere. A Selective Catalytic Reduction reactor (SCR) is installed in the flue duct to minimize NOx emissions. High pressure steam is produced by the SMR for use as process steam and for export from the facility.

The new equipment proposed includes two new VPSA/Cold Box hybrid units, each integrated with one of the existing SMR plants. Referring to Figure 1, a VPSA/Cold Box system is integrated with each existing SMR immediately prior to each SMR's PSA system. Within the VPSA/Cold Box battery limits, the $\mathrm{CO}_{2}$ is purified and compressed. The project would also include compression for delivery of the $\mathrm{CO}_{2}$ to the pipeline for subsequent sequestration through EOR. The $\mathrm{CO}_{2}$ is then transported via connector pipeline to the Green Pipeline owned by a Denbury affiliate that supplies $\mathrm{CO}_{2}$ to Denbury's EOR fields. The Green Pipeline supplies $\mathrm{CO}_{2}$ to several EOR fields and all the captured $\mathrm{CO}_{2}$ that enters the Green Pipeline would be sequestered at one of the EOR locations. For the purposes of conducting MVA activities, Hastings field was chosen. This field has more than adequate $\mathrm{CO}_{2}$ storage capacity.

\subsection{Project Management}

\subsubsection{Project Management, Planning and Reporting}

The ICCS project consists of two parallel projects that would be executed concurrently. Praxair would be performing the integration, capture, purification and compression of the $\mathrm{CO}_{2}$ removed from the SMR syngas. Denbury would be responsible for arranging the transportation, and injection activities. Additionally, GCCC would be a third tier subcontractor under contract to Denbury to perform the research measurement, verification and monitoring project for the stored $\mathrm{CO}_{2}$. 


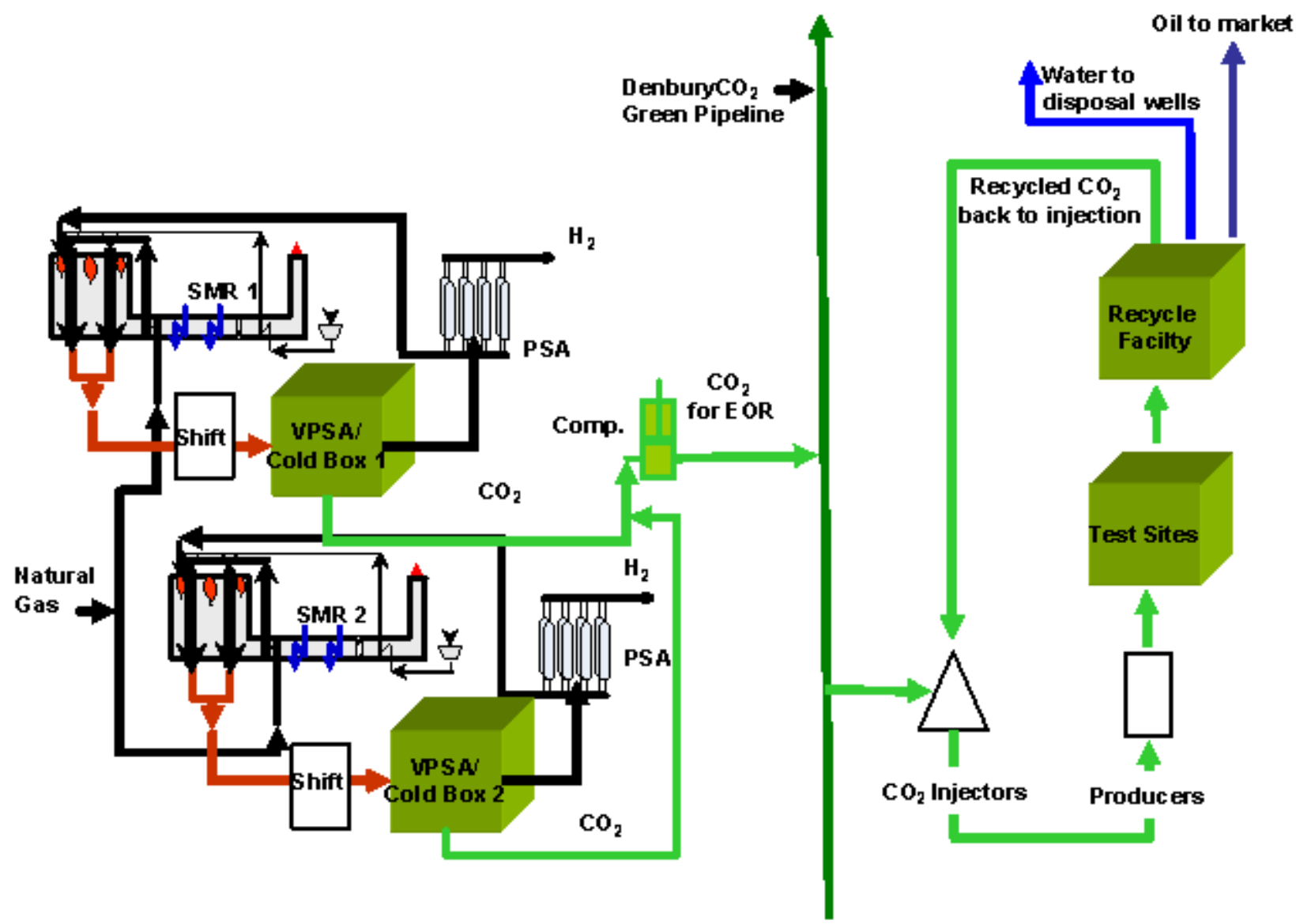

Figure 1: Overall Block Flow Diagram for the Carbon Capture System (CCS) Project

The Project Team would perform all project management activities (i.e., planning, tracking, executing, controlling, and communicating) necessary to meet technical, cost, and schedule goals per the Cooperative Agreement. The technical, cost, and schedule information would be updated and reported. The activities would include environmental permitting and compliance.

Praxair would employ current project management principles, including earned value management, to track completion of work, to keep activities on schedule, and to control costs to remain within the budget. During Phase 1, a detailed PMP including a design baseline scope document and design schedule was developed. The PMP would be updated for the overall schedule, cost, and integration for all the components that constitute the project. Additionally, the overall risk mitigation plan would be executed.

\subsubsection{Project Manager}

The project manager would coordinate all activities associated with process and equipment engineering, design engineering, and safety engineering for the Carbon Capture and Sequestration Project. The project manager would also update capital and operating costs. Additionally, the project manager would update project management, procurement and construction plans for the Carbon Capture and Sequestration Project. 


\subsubsection{Project Management Plan}

The statements of work and procurement packages would be developed for major subcontracts. The Project Management Plan includes the following: project schedules and milestones, risk management, funding and costing profile, resource-loaded schedule, project management organization, roles and responsibilities, key personnel, work breakdown structure, communications, project monitoring, and change control and process improvement.

The project management includes the following business functions to support the project: implementing the appropriate cost accounting, property management, procurement methods, and human resources guidelines to meet all Federal, State, and local regulations and standards.

The Project team would implement and manage the project and report on activities in accordance with the approved Project Management Plan. The Project team would update the Project Management Plan if project management policies and procedures are changed, if rebaselining is required, if significant changes in scope, methods or approaches are required, or as otherwise required to ensure that it is the appropriate governing plan for the work required to accomplish the project objectives.

\subsubsection{Procurement and Contracting}

The plan created in Phase 1, would be executed for the procurement of the equipment, fabrication, and construction of the Carbon Capture and Sequestration Project. Final bid documents for equipment, fabrication and construction to qualified vendors would be issued. The procurement plan for the Carbon Capture and Sequestration Project would comply with approved procurement procedures.

\subsubsection{Construction Plan}

The integration, capture, and compression systems construction plans would be reviewed and updated to ensure the safety and constructability of the $\mathrm{CO}_{2}$ VPSA/Cold Box Hybrid Units and SMR Integration at Praxair's $\mathrm{H}_{2}$ production facility. The construction plan would dictate the necessary provisions that need to be established to ensure safe $\mathrm{CO}_{2}$ VPSA/Cold Box Hybrid Units construction, SMR Integration construction and the overall site construction activities.

The transportation, injection and MVA construction plan would be reviewed and updated to ensure the safety and constructability of the pipeline between Praxair's $\mathrm{H}_{2}$ production facility and the sequestration field. The plan would address required permits, right-of-ways, and other necessary environmental studies that are needed for construction. The construction plan would also dictate the necessary provisions that need to be established to ensure safety during construction.

\subsubsection{Scope Management}

Based on the engineering efforts, the design baseline scope document developed in Phase 1 would be revised to reflect the expected performance. Update the construction baseline to be the template for use during Phase $2 \mathrm{~B}$.

\subsubsection{Design Schedule}

The design schedule developed in Phase 1 would be revised to reflect the schedule required to complete the design phase of the Carbon Capture and Sequestration Project. Phase 2A would be managed to meet the schedule requirements. 


\subsubsection{Construction and Operation Schedule}

The schedule for Phases $2 \mathrm{~B}$ and $2 \mathrm{C}$ would be updated to ensure the overall project schedule meets the needs of the project and remains manageable under the site constraints of the project site.

\subsubsection{Overall Risk Management Plan}

The risk plan for the Carbon Capture and Sequestration Project would be updated to reflect the effects of risk mitigation plans that have been implemented since the previous risk plan. Additionally, the risk plan update would include any newly identified risks associated with the Carbon Capture and Sequestration Project and a mitigation plan for these risks would be implemented as required.

\subsubsection{Commissioning and Demonstration Plan}

Resources and needs would be identified for the commissioning and demonstration of the $\mathrm{CO}_{2}$ capture, Integration and Compression systems as well as the $\mathrm{CO}_{2}$ transport, Injection, Sequestration and MVA activities to meet the requirements of the Recovery Act: Carbon Capture and Sequestration from Industrial Sources and Innovative Concepts for Beneficial $\mathrm{CO}_{2}$ Use FOA.

\section{$2.2 \quad$ Risk Plan}

\subsubsection{Risk Management}

The Risk Management Plan describes the project management approach and tools that the project would use for risk management, including a risk identification checklist, probability, and updates to track progress on risk mitigation. The process ensures consistent and disciplined risk evaluation and mitigation.

The overall approach to risk management is based on our detailed methodology for identifying, assessing and handling technical, performance and programmatic risk. The integrated approach ties risk to the Work Breakdown Structure and the integrated baseline. It anticipates known and unplanned risks and establishes control mechanisms to manage and minimize or eliminate adverse impacts on project cost and schedule.

It is an on-going process and is integrated into day-to-day project management activities and systems, providing real-time interaction of the project risk profile in with each of the major activities. Our approach provides for continual re-assessment of risks. It is iterative and applies to all phases of project execution.

\subsubsection{Risk Planning}

Risk planning is defined by the program objective components and the steps for planned implementation. Included are developing and assigning organizational responsibilities, processes, tools and expectations. Risk planning ensures that each scope area, as well as, the overall program is covered.

Monte Carlo probabilistic analysis to characterize the likelihood of a given risk of each potential event's occurrence and the respective consequences has been used. The analysis is based on the impact to the baseline cost and schedule. The project team includes this data to establish project plans, and track mitigation and contingencies. 
Individuals are responsible for risks in their assigned areas of responsibility and for recognizing risks related to work scope. When risk is identified, whether emerging or existing, they should formulate alternative plans that eliminate, avoid or mitigate the risks.

\subsubsection{Risk Identification and Analysis}

Risks are identified by identifying uncertainties through brainstorming and reviewing the scope, schedule and cost estimate assumptions of the project. In addition to evaluating the scope of work for uncertainties, programmatic risks are considered. A risk identification checklist is used to aid in discussions.

Risk screening guideline evaluations include uncertainties associated with items such as technology, physical interface, safety, regulations, assumptions, resources, equipment, and procurement from a project and programmatic perspective. Specific project segments assessed for this project included: Commercial, Sequestration, Lateral Pipe Line, MVA, and Carbon Capture System

\subsubsection{Risk Probability and Impact}

Risks are assessed in terms of assessing probability of occurrence, severity of consequences, and categorizing the risks as high, moderate or low, depending on their probability and severity of consequences. Risks are analyzed to identify the likely impact, should the uncertainty become a reality. The cost or schedule impacts are assessed. (Schedule impact is converted to cost, e.g., impact to the critical path results in carrying project cost for that time period.) The project/facility team and technical and risk experts assess the maximum likely cost.

\subsubsection{Risk Mitigation - Mitigate and Close Risk}

A risk mitigation plan is formulated for each high- or moderate-risk event to ensure that the necessary actions to mitigate or close the risks are scheduled, estimated, and included in project forecast.

The proactive approach integrates programmatic and performance risk management into one effective program. The strategy is simple: identify, assess, mitigate, track, continually reevaluate, and report. To mitigate the risk by specific scheduled actions, or not, the estimated residual risk and recommend risk contingency levels using a Monte-Carlo analysis technique produces recommended contingency at various confidence levels.

Risks are formally closed when probability or consequences go to zero. Part of the closure process entails capturing lessons learned and best practices to apply to other emerging risk or to other projects/facilities as part of continuous improvement.

During the Phase 1, definition, internal management and external 3rd party risk reviews were conducted.

\section{3 $\mathrm{CO}_{2}$ Capture, Integration, and $\mathrm{CO}_{2}$ Compression}

\subsection{1 $\mathrm{CO}_{2}$ VPSA/Cold Box Hybrid Units and SMR Integration}

\subsubsection{1 $\quad \mathrm{CO}_{2}$ VPSA/Cold Box Hybrid Units}

Praxair's concept, as shown in Figure 2, is to divert the syngas produced in the SMR to a $\mathrm{CO}_{2}$ VPSA. This unit will capture $\mathrm{CO}_{2}$ and return the $\mathrm{CO}_{2}$ free stream to the $\mathrm{H}_{2}$ PSA. The VPSA unit will adsorb $\mathrm{CO}_{2}$ while letting other gases pass through. $\mathrm{CO}_{2}$ will be desorbed from the adsorber vessel by evacuating it to a low pressure. The $\mathrm{CO}_{2}$-rich stream from the VPSA will be sent to a 
cold box for final purification. The VPSA unit will consist of a multi-bed system with one bed always on the feed while other beds are going through regeneration steps. The VPSA cycle is designed to ensure a continuous mode of operation for feed entering the VPSA unit and product withdrawn from it while operation of each bed is in a cyclic steady state. A unique cryogenic distillation-based cycle (reboiled absorber) is used for production of gaseous high purity $\mathrm{CO}_{2}$ (greater than $99 \%$ ). Figure 2 is a process flow diagram for the overall VPSA and cold box.

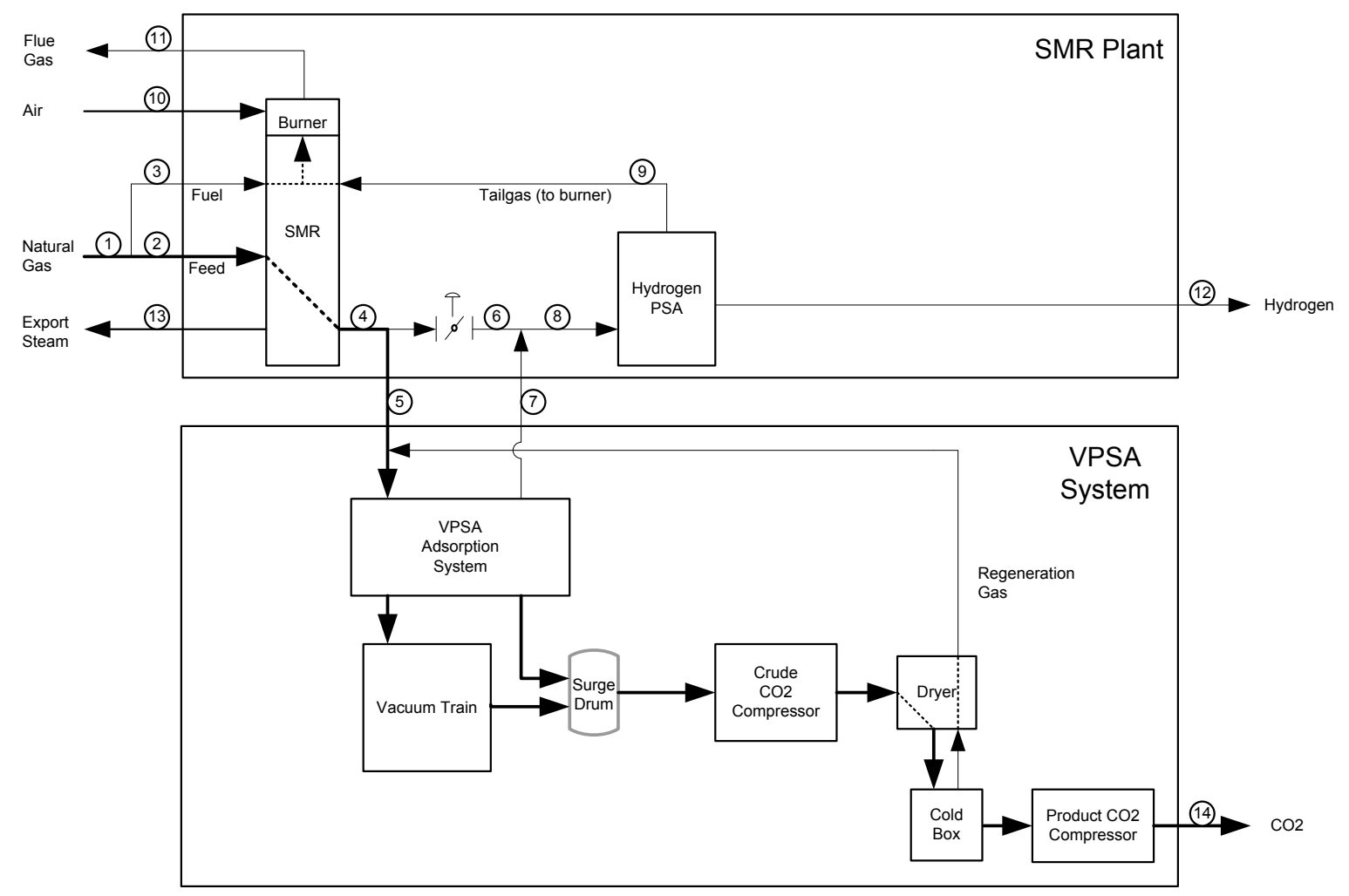

Figure 2: Novel Hybrid (VPSA and Cold Box) Process Flow Diagram

\subsubsection{SMR Integration}

The $\mathrm{CO}_{2}$ VPSA/Cold Box hybrid system captures approximately $95 \%$ of the contained carbon dioxide. The resulting lean syngas, low in carbon dioxide, is then fed to the PSA system where hydrogen purification occurs. The resultant tailgas stream from the PSA system, thus, has significantly reduced carbon dioxide content.

Tailgas from the PSA system is combined with natural gas fuel, fed to the reformer burners, and combusted in order to satisfy reformer duty requirements. The burner gas heating value is increased from design because of the rejected $\mathrm{CO}_{2}$ resulting in significantly higher NOx production in the burners. The project mitigates this with a substantial increase in the size and performance of the SCR system. The lower $\mathrm{CO}_{2}$ content also results in a reduction in the production of steam in the waste heat (flue gas) section of the plant.

Major project scope items relating to the integration of the $\mathrm{CO}_{2}$ Recovery System with the HU-3 and HU-4 SMR facilities include:

1. Larger SCR Reactor, New Ammonia Flow Control Unit, New Ammonia Injection Grid

2. SMR Control System Modifications 
3. PSA System Physical and Control System Modifications

4. Additional Analytical Equipment

\subsubsection{SMR Integration Process Studies}

1. SCR System Computational Fluid Dynamic Analysis. Computational Fluid Dynamics (CFD) analysis of the existing and proposed future duct work, SCR catalyst, and Ammonia Injection Grid (AIG) was conducted to investigate the effect of catalyst plugging from Lower Heating Value (LHV) refractory fines.

The CFD model was run on both the existing and the proposed future duct unit assuming that the catalyst had no blockage at all. With no blockage, the flow is symmetrical and well balanced. With blockage in the catalyst, the velocity and the ammonia mass flow rate profiles changed because of the higher resistance of the bottom and middle parts of the catalyst.

2. Reformer Dynamic Process Simulation. Using a dynamic process simulation model, a study was conducted for the HU-4 reformer to determine the impact of a sudden and complete trip of the proposed VPSA/Cold box CCS on HU-4 SMR operation.

Reformer process dynamics are represented with a dynamic process simulation model. Scope of the model includes the entire reformer with the exception of the demineralized water supply unit, cooling water system. Actual equipment size and geometry are part of the model. Actual performance characteristics for the rotating equipment are used in the model. For heat exchangers, UA is scaled automatically by the simulator. Burner performance is modeled using the burner performance curves. The reforming and shift reactions are modeled kinetically with the appropriate catalyst physical properties to represent the tubes and the shift reactor. PSA purge gas composition and flow are calculated from the component recoveries. The dynamic model is also equipped with a complete control system to closely emulate the existing control system at the plant.

\subsubsection{Process Engineering}

\subsubsection{Utility Summary}

The utilities required for the carbon capture system would be made available at the existing site. The following utilities are required for the carbon capture system:

1. Natural Gas

2. High Pressure Steam

3. Boiler Feed Water

4. Demineralized Water

5. Cooling Water

6. Nitrogen for instrument gas and purge

7. Electric Power

8. Service Water

9. Potable Water

10. Aqueous Ammonia

11. Plant Air

12. Fire Water

13. Service Steam 


\subsubsection{Equipment List:}

\section{Carbon Capture System Inside Battery Limits (ISBL) Equipment List}

Vacuum Pumps

VPSA Adsorber Vessels

Blow Down / Evacuation Storage / Surge Vessels

VPSA Valve Skids

Feed Compressor

Dryer Package

Water Chiller

Dryer Inlet Chiller

Dryer Inlet Separator

Dryer Beds

Regen Gas Heater

Particulate Filter

Regen Gas Cooler

Regen Gas Separator

Steam De-superheater

$\mathrm{CO}_{2}$ Cold Box

Primary Heat Exchanger

Inlet Column Separator

Distillation Column

Product $\mathrm{CO}_{2}$ Compressor

Analytical Equipment

\section{Carbon Capture System Outside Battery Limits (OSBL) Equipment List}

Cooling Water Pumps

Selective Catalytic Reduction Unit Modifications

Ammonia Injection Grid (AIG) Modifications

Ammonia Flow Control Unit (Skid)

Flue Gas Duct Modification

Analytical Equipment

\subsubsection{Equipment Engineering}

Equipment engineering and selection during the Phase 1 work followed a well defined work process. Based on process conditions, procurement quality equipment specifications were developed for all major equipment. These project specific specifications build on already existing standard specifications developed by Praxair based on operations and project execution experience. Equipment specifications included such information as:

- Required Scope of Equipment Supply

- Process Conditions

- Materials of Construction 
- Performance Requirements

- Utility Requirements

- Code Requirements

- Fabrication Procedures \& Guidelines

- Applicable Existing Praxair Standards

Equipment specifications were provided to multiple Praxair approved equipment vendors for quotation. These vendors have existing knowledge of Praxair's equipment design and fabrication requirements based on a rigorous qualification process used to ensure robust designs and reliable operation. Vendor quotations were then evaluated based on capital, utility, maintenance and reliability requirements to understand the full life cycle cost before making equipment selections. Based on evaluated equipment selections, preliminary project deliverables were created to document project scope. This work formed the basis for the overall cost estimate discussed below.

\subsubsection{Plant Design and Layout}

The site for installation of the new $\mathrm{CO}_{2}$ VPSA systems would be Praxair's $\mathrm{H}_{2}$ operating facility located within BP's Texas City refinery. The plot for the equipment for each $\mathrm{CO}_{2}$ VPSA train would be approximately 500 feet $\times 150$ feet. Each $\mathrm{CO}_{2}$ VPSA train would be located adjacent to its respective SMR. The HU3 $\mathrm{CO}_{2}$ VPSA train would be located west of the existing HU3 SMR equipment on a new parcel of land. The HU4 $\mathrm{CO}_{2}$ VPSA train would be located south of the existing HU4 SMR equipment on a new parcel of land. A new electrical substation would be installed to supply power to the new $\mathrm{CO}_{2}$ VPSA loads. The new substation would be approximately 100 feet $\times 100$ feet and would be located to the west of the existing HU1 SMR equipment on the new parcel with the $\mathrm{HU} 3 \mathrm{CO}_{2}$ VPSA train. (See Plant layout attached as a graphical material attachment at the end of this report.) Power lines would be installed to connect the substation to existing power infrastructure. Syngas, cooling water, instrument air, flare and nitrogen tie-ins are located within 500 feet of the proposed new equipment areas. The existing site cooling tower and cooling water pumps would be upgraded to meet the additional cooling water requirements for the new $\mathrm{CO}_{2}$ VPSA equipment. Soil borings/geotechnical reports obtained from the existing facility identify the existing soil conditions and soil stabilization and dewatering requirements. Foundations and underground piping from existing equipment would need to be relocated as part of the site preparation phase of construction.

\subsubsection{Design Safety and Project Safety Plan}

\subsubsection{Process Hazard Analysis}

Based on the complex and first of a kind nature of the capture project, a HAZID was conducted. A HAZID involves the identification of the possible hazards that may be present within new/firstof-a-kind processes, changes to existing processes, and upgrades/modifications to existing facilities. This study provides early identification of project specific hazards with emphasis on hazards not covered by existing Praxair standards and the material or situation in which the hazard may occur. A HAZID also provides input to the selection of the appropriate PHA methodology that would be used in later phases of the project. In order to drive hazard recognition from various technical areas and resources, the study team was comprised of experienced individuals from a diverse skill set including operations, process engineering, equipment engineering, plant design, advanced control systems, and safety. 
The following list is an example of the types of hazards discussed during the HAZID meetings.

- Six Hazards that Kill

- Process Hazards

- Process Materials

- Environmental Hazards

- Enablers

- Hazardous Conditions

Two Process HAZID meetings were completed on January 19, 2010 and February 11, 2010. The first HAZID was focused on the $\mathrm{CO}_{2}$ VPSA/Hybrid system and the second HAZID was focused on the SMR Integration.

All action items would be addressed during the project execution phase of this project.

The Facility siting study would need to be updated to reflect the new VPSA equipment. Vacuum of operating vessels connected via relief or vent valves, to the site flare system would need to be reviewed for potential back-flow of gases into vessels while operating under vacuum. Orientation of high pressure PSV discharges would be considered for incorporation of noise shields as needed. Costs associated with these actions became part of the overall cost estimate.

The following Process Safety meetings would be scheduled for this project

- Two HAZOPs would be performed for this project, one for the CO2 VPSA/Hybrid systems and one for the SMR integration.

- Layout Review Meeting

- Electrical Area Classification Drawing Review Meeting

\subsubsection{Local Regional Safety \& Environmental Services Involvement}

S\&ES Initial business risk assessment recommendations were included in scope. Permit application process was reviewed with S\&ES. Timely and accurate permit submittals would be required to ensure that the application process does not delay the project schedule.

\subsubsection{National Environmental Policy Act (NEPA)}

As an output of the EIV prepared during the Phase 1, the Praxair environmental manager would work with the DOE environmental manager and an approved environmental consultant to complete the requirements of an Environmental Assessment (EA) or Environmental Impact Study (EIS). Determination on whether an EA or EIS is required would have been determined by the DOE prior to project award. As defined in the Cooperative Agreement with DOE, work cannot proceed to the Phase $2 \mathrm{~B}$, Construction, until all approvals under the EA or EIS have been satisfied.

\subsubsection{OSHA PSM Applicability}

The existing plant is not a PSM facility. The new equipment does not change this status.

\subsubsection{Design Safety Checklists}

Standard Praxair Safety Checklists as applicable would be completed during project execution. 


\subsubsection{Inspections}

A QA/QC plan would be developed and would include Inspection for suppliers and fabricated equipment. Safety inspections of the construction work would be performed as shown in the project schedule.

\subsubsection{Capital and Operating Cost Estimates}

The facility would be the first of its kind to integrate all processes into a Steam Methane Reformer for commercial operation, providing the basis for broad commercial implementation of this technology. Praxair followed our Front-End Loading 2 process with the output of a functional design, equipment quotes, project plan and capital cost estimate. Operability was included. All elements of the integrated facility would be operated in concert, safely and efficiently, while meeting all permit requirements. Praxair is capable of safely supporting the long-term operations and maintenance of these facilities. The impact on the operating and maintenance costs of the SMR with integrated carbon capture system has been evaluated.

\subsubsection{Cost Estimate}

Procurement quality specifications were developed to solicit firm budgetary quotes for fabrication of the major equipment. Representative conceptual construction drawings and specifications were developed to obtain contractor quotations and key quantities. Detailed task level engineering plans were used to obtain detailed engineering estimates for internal and external resources.

\subsubsection{Schedule}

A detailed task level critical path schedule was developed using durations and logic from equipment fabricators, construction contractors and various engineering disciplines.

\subsubsection{Cash Flow}

Engineering plans, contractor and fabricator schedules and payment milestones were used to develop the cash flow forecast for the capital expenditures on the project.

\subsubsection{Operating Costs}

The plant operating cost impact has been determined. The effect on the existing SMR operating costs was taken into account. Systems and supplies for utilities were determined during the Phase 1 study.

Personnel staffing needs for operation including technician, supervision, engineering, and environmental monitoring has been determined and built into the operating costs. Synergies with the existing facility operation were considered.

Utility costs for each piece of equipment for the carbon capture system have been determined. This utility cost were also factored into the engineering process when designing and selecting equipment.

\subsubsection{Maintenance Costs}

Plant maintenance needs were determined from data for equipment in operation similar to that proposed for the carbon capture system. To maximize plant availability, maintenance plans included preventative maintenance/monitoring, maintenance during brief shutdowns and maintenance during Turn Around Schedules. Spare parts were also assessed as part of the project. 
Many preventative maintenance and monitoring tasks can be conducted during normal plant operation. These routine tasks and inspections are important in that they can minimize the cost impact, number and duration of scheduled and unplanned shutdowns, and the potential degradation of performance.

Praxair treats outages as a rare occurrence. It is critical to take full advantage of any shutdowns that becomes available. A plan coordinating outage requirements would be developed for each occurrence.

- Brief outages are planned and costs determined for valve, chiller, cooler, instrumentation, and relief valve maintenance.

- Longer Turn Around outages are scheduled and costs determined for SMR components, bed adsorbent replacement, motor reconditioning and compressor overhauls.

With Praxair's skilled plant operation and carefully planned maintenance activities, plant reliability is maximized and long term operability is ensured.

The result of this capital and operating cost estimate was one of the critical contributors to the decision not to proceed with Phase 2.

\subsubsection{Procurement Plan}

The Praxair Global Procurement \& Materials Management Group would handle purchasing, contract administration \& transportation for all material required for this project (Figure 3 ). Upon approval to proceed to Phase 2B, all long lead equipment would be ordered within one month. Long Lead equipment was quoted using proposal quality specifications along with first rounds of comments on clarifications and exceptions. No problems are anticipated with the order of the remaining major equipment.

The HYCO Project Controls/QA \& Materials Management group would be responsible for tracking the equipment \& materials purchased for the project and coordinating with Transportation group for the delivery of goods to the site. The Procurement \& Transportation Plan would be used for this project. It is intended that the Materials Management Coordinator would expedite materials and handle the coordination of supplier drawing submittals.

All contracts would be issued and administered on a cost reimbursable or lump sum fixed price basis. Checked drawings would be completed prior to contract award and field changes would be administered very tightly by the field construction manager (FCM). Labor is open shop or union. All local contractors would be required to comply with Davis Bacon Act requirements for paying Department of Labor published prevailing wages for all field construction work.

Preliminary bid documents for equipment, fabrication and construction to qualified vendors would be issued per Praxair Standards and Guidelines. 


\begin{tabular}{|c|c|c|c|c|c|c|c|c|c|c|c|}
\hline \begin{tabular}{|c|} 
Need \\
Established, \\
Specification \\
Generated, \& \\
Inventory \\
Checked
\end{tabular} & $\begin{array}{c}\text { Delivery } \\
\text { Date and } \\
\text { Ship to } \\
\text { Determined }\end{array}$ & $\begin{array}{l}\text { Pricing } \\
\text { Estimated, } \\
\text { potential } \\
\text { suppliers } \\
\text { known, } \\
\text { taxability } \\
\text { known }\end{array}$ & $-\begin{array}{c}\text { Budget } \\
\text { established in } \\
\text { system and } \\
\text { management } \\
\text { approval }\end{array}$ & $\begin{array}{c}\text { Blanket, Time } \\
\text { Span, Recurring } \\
\text { Payment, } \\
\text { Corporate price } \\
\text { agreement } \\
\text { established? }\end{array}$ & -Yes & $\begin{array}{c}\text { No- } \\
\text { Follow } \\
\text { GPMM-601.4 } \\
\text { and work } \\
\text { direct with } \\
\text { sunnlier }\end{array}$ & $\begin{array}{l}\text { Emergency } \\
\text { Order, } \\
\text { check } \\
\text { request or } \\
<\$ 2000 \\
\text { One Card? }\end{array}$ & -Yes- & $\begin{array}{c}\text { Follow } \\
\text { GPMM-601.4 } \\
\text { and work } \\
\text { direct with } \\
\text { supplier }\end{array}$ & \begin{tabular}{|c|} 
Follow \\
GPMM-601.2 \\
and Issue \\
Requisition to \\
Buyer
\end{tabular} & $\begin{array}{l}\text { Receive } \\
\text { and } \\
\text { Inspect }\end{array}$ \\
\hline
\end{tabular}

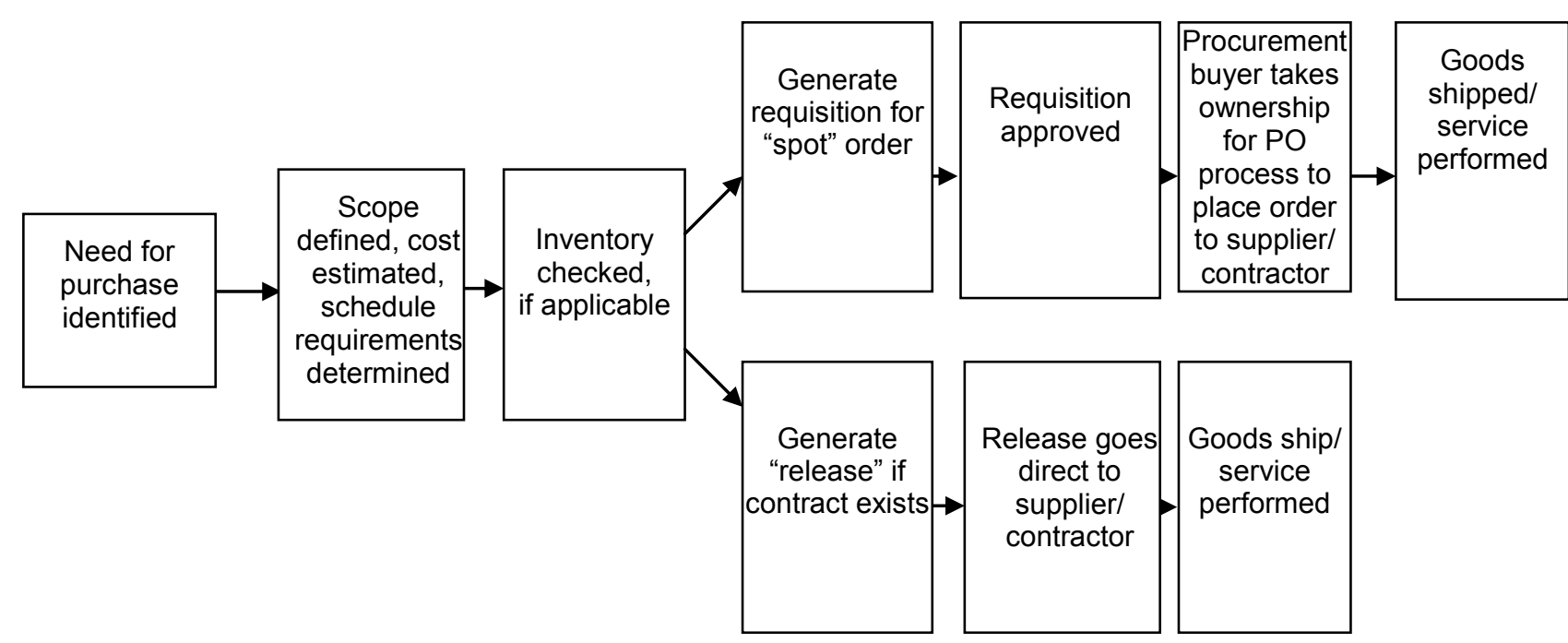

Figure 3: Global Procurement and Materials Management Group

\section{Procurement Standards}

PO-601, Purchasing Process

PO-626, Supplier Qualification

PO-641, Supplier Nonconformity Review and Corrective Action

\section{Procurement Guidelines}

GPMM-601.2, The Requisitioning Process

GPMM-601.6, Purchasing Record Retention

GPMM-602.1, Purchasing Authority

GPMM-602.2, Creation, Approval and Issue of Purchasing Documents

GPMM-602.3, Standard Terms and Conditions

GPMM-602.4, Standard Purchasing Document Templates

\section{Procurement Forms}

F-GPMM-601.4.1-NA, Purchase Authorization and Savings Record (PACRR)

Check Requisition Form, Airwaves/Reference Desk/Corporate Policies/Procurement Procedures/Policy 


\subsubsection{Construction Plan}

\subsubsection{Construction Management}

Construction management would be performed to complete civil, mechanical, electrical, and instrumentation construction of the $\mathrm{CO}_{2}$ VPSA/Cold Box Hybrid Units and SMR Integration. Near the end of the construction period, the mechanical, electrical, and instrumentation would be commissioned to allow transition to the demonstration phase. All cost estimates updated during the design phase would be tracked versus actual expenditures to ensure the $\mathrm{CO}_{2}$ VPSA/Cold Box Hybrid Units and SMR Integration construction and commissioning would have been completed on schedule and within the budget defined. During engineering any updates in new risks for process, construction, commissioning, and demonstration periods would be identified to assemble the plans to mitigate the risks.

\subsubsection{Construction Safety}

High risk areas for construction would be addressed in the contractor's Site Specific Safety Plan (SSSP). All construction work within the designated construction area would be performed under CHWP's (Construction Hazardous Work Permit) issued by the Praxair Construction Management Team. All OSBL (Outside Battery Limit) and tie-in work would be performed under HWP's (Hazardous Work Permit) issued by Praxair Plant Operations.

Extensive mechanical tie-ins and other OSBL utilities would be required for the project. All equipment related to the core $\mathrm{CO}_{2}$ VPSA/Hybrid process would be new construction - no relocated or modified equipment.

The area where the new equipment would be located has existing foundations and underground utilities that would need to be removed prior to installation of new foundations. Hydrovac would be used to determine the location of all existing foundations and utilities.

Specific activities would be undertaken to ensure the safe construction of the $\mathrm{CO}_{2}$ VPSA/Cold Box Hybrid Units and SMR Integration. High hazard work would be identified and written plans would be assembled with instructions on how to mitigate the hazards associated with construction safety prior to initiating the hazardous work.

The site is located inside the BP Texas City Refinery but the work is not required to follow BP or API rules. No other unique customer requirements have safety impacts.

\subsubsection{Special Training Requirements}

All Praxair Team members that would be performing work on site such as the Construction Manager, the Commissioning Team, etc. are required to go through Texas City Safety Council, BP and Praxair site specific training. This training takes approximately one working day to complete. The orientation and training is valid for one year.

\subsubsection{Visitor Requirements}

All Praxair visitors must view a 30 minute BP safety orientation video prior to entering the facility. The orientation and training is valid for one year. Vehicles would be limited on the site. All vehicles would be subject to a search entering and leaving the site. All visitors would be escorted and receive a visitor briefing (required at all times) prior to entering the facility. Visitors would stay with their escort. Also, all Praxair visitors should notify the CM prior to scheduling a visit to ensure that all required individual PPE is available to address the specific hazards present at the jobsite. 


\subsubsection{Site Safety Representation}

Contractors would provide safety professionals to:

- establish safety programs

- train personnel

- orient visitors

- monitor on-going work

- audit work procedures and documentation for compliance with plans

- investigate near misses and incidents to prevent reoccurrence

Praxair would also provide safety professionals to work with the contractors to ensure the SSSP meet Praxair requirements and to audit compliance.

\subsubsection{Contractor Construction Safety Site Specific Safety Plan (SSSP)}

The purpose of this plan is to assist us in accomplishing our goals by identifying

- The issues that affect safety of the project

- Responsible parties for the listed elements of the plan

This plan incorporates the requirements of Praxair Contractor Rules for Construction Safety (P-15-264C).

There could be approximately 200 construction personnel on site during the peak construction periods. In order to ensure safety during the construction phase of this project we have include periodic safety audits to provide a working environment free of hazards. Full time safety supervision from Praxair and the contractor would be on-site during the peak construction period and the two plant turnaround/outages. A Constructability Review Meeting would be scheduled to assist the project team in reviewing possible hazards that could be encountered during the construction phase of the project.

Tie-ins and OSBL utility work would be within the existing Praxair HYCO SMR operating facilities and would fall under the Praxair Hazardous Work Permit Procedures with HWP's issued by Praxair Plant Operations. For "High Risk" work, Praxair would review specific documents related to the work. All other work requiring permits (CHWP's) would be issued by the Construction Manager.

All contractors are responsible to manage their Site Specific Safety Plan during all construction activities and to ensure that their plan is executed as written.

The work would be located within and near the existing Praxair SMR operating equipment. The existing process facilities would be on-stream during the duration of this work. All personnel working in the vicinity of the existing SMRs would be required to wear personal CO monitors. The contractor must supply all of his personnel with personal $\mathrm{CO}$ monitors. Training on the hazards of $\mathrm{CO}$ is included in the Praxair site specific training which is conducted during site orientation.

Specific control measures to minimize site hazards are to be reviewed during the site kick off meeting. (Hard barricades by roadway, roped off areas etc.) 
Contractor personnel are to be kept in the immediate area of their work or at the construction trailer. Any individual going outside of the designated work area would require approval of Praxair.

Safety audits and/or assessments would be performed weekly during the work.

Praxair Field Construction Management and/or the Praxair Site Safety Manager would review contractor practices to the Site Specific Safety Plan, Confined Space, Lockout / Tag-out, HWP, and Contractor Rules for Construction Safety.

\subsubsection{Checkout and Commissioning}

Coordination occurs between construction management, contractor, and the commissioning team, to ensure commissioning safety through the project.

Both a Pre-Startup Safety Review (PSSR) and a Pre-Startup Management Review would be conducted.

Prior to commissioning, a "readiness" assessment would be made for each phase per the Walkdown/ Punch-list Guideline consisting of:

- Design Safety Walk-down

- $\quad$ PSSR Meeting on site per SA-1

Proper training would need to be provided for operation of the $\mathrm{CO}_{2}$ VPSA/Hybrid Systems and SMR Integration. Specific training on VPSA operation, vacuum blower operation, trouble shooting and maintenance would need to be provided. New Standard Operating Procedures (SOPs) and Standard Maintenance Procedures (SMPs) would need to be developed for the new $\mathrm{CO}_{2}$ systems and existing SOPs and SMPs would need to be updated to reflect the SMR integration modifications to both SMRs.

\subsubsection{Construction Management Field Organization}

Owner field construction management staffing for this job would be divided into four categories during construction:

- HU3/HU4 modification

- Capture civil work and substation

- Capture mechanical, electrical, and instrumentation

- Capture site close out, commissioning, and startup

The core of the field staffing team would consist of a Praxair field construction manager who would have overall site management responsibility for the duration of the project. The core team would also have a $3^{\text {rd }}$ party project controls engineer, safety manager and an administrative assistant. The core team would be on site for the entire construction duration of Phase 2B. Project controls would be critical for this project. The project team must ensure that it is able to meet all of the Department of Energy progressing and reporting requirements. $3^{\text {rd }}$ party personnel would most likely be available from the greater Houston area. Contact would be made with local service providers.

An additional $3^{\text {rd }}$ party Assistant Field Construction Manager (FCM) would augment the core field team during the SMR modification field work. This would enable the field team to adequately support the contractor for work done during second shifts or overtime. 
Another $3^{\text {rd }}$ party Assistant FCM would be added to the field team during the civil/substation work. This would allow proper focus to be allocated to the substation work while the civil and modification work would be progressing.

When the mechanical portion of the work starts there would be a $3^{\text {rd }}$ party Assistant FCM and QC manager added to the core field team. This team would remain intact for the electrical and instrumentation work and ensure adequate contractor oversight would be in place during this portion of the work.

As the project moves to close out and starts the commissioning phase the core field team would still be present and would be augmented for a portion of this work with the QC manager.

Construction field work would not commence until the design work would be completed during Phase 2A. Construction support would be planned for usage during this phase for the planning of the HU3/HU4 modification/tie in work and overall project planning.

\subsubsection{Constructability}

The strategy for this project would be to utilize a general contractor that would have the experience and expertise to complete a Government funded project in the Texas City, TX area on a BP site. The general contractor and key project team personnel would be expected to schedule and take part in constructability efforts to ensure the work is optimized. Multiple planning meetings would be conducted to:

- Review preliminary construction schedule

- Finalize execution strategy and contracting approach

- Finalize plant layout

- Develop high level construction sequence

- Review details of major equipment, transportation, installation and delivery schedules

- Identify critical path equipment and crane usage

- Identify opportunities and roadblocks that affect the contractor's ability to perform work efficiently

- Identify plan for modularization and assess any offsite fabrication opportunities

- Address any parallel work and the opportunities and associated management challenges that it presents

- Review of all governmental progress, cost, schedule and safety reporting requirements

During the construction phase, weekly meetings would take place involving the project team to discuss approaches for the optimization and risk mitigation through pre-planning or detailed planning of work activities using lean construction techniques.

\subsubsection{Civil Construction}

Civil construction of the $\mathrm{CO}_{2}$ VPSA/Cold Box Hybrid Units and SMR Integration at the Texas City $\mathrm{H}_{2}$ facility would be executed. The necessary excavation, underground electrical and grounding would be installed in accordance with the designs. This work includes necessary site preparation, demolition, foundation installation and underground utility installation. 


\subsubsection{Mechanical Construction}

During the mechanical construction phase, installation of Carbon Capture equipment and interconnecting piping would be completed. Piping interconnects between the existing Hydrogen SMR units and the Carbon Capture systems would be completed. Upgrades and modifications to the existing Hydrogen SMR units would be completed. Additionally, testing of pressure piping and pressure vessels, as required, would be performed. This work includes the setting and erection of all the necessary equipment, steel and piping installation.

\subsubsection{Electrical Construction}

Control system cabinets would be fabricated and installed with the associated hardware and software. Instrumentation required for operation and data acquisition would be installed. Control and instrumentation wiring necessary for controls and metering would be run to control system cabinets to allow for the electrical needs of the $\mathrm{CO}_{2}$ VPSA/Cold Box Hybrid Units and SMR Integration equipment.

\subsubsection{Construction Plan}

The construction plan would address the requirements of Phase $2 \mathrm{~B}$ of the project. Unique aspects of this project include:

- Constrained site conditions

- Working in an operational facility

- Plant outages

- Complying with the administrative requirements of the Department of Energy (DOE)

- Decision points - In accordance with the "DECISION POINT" provision of the Model Cooperative Agreement, Praxair is not authorized to proceed beyond Subphase 2a Design without written approval of the DOE Contracting Officer for continuation into Subphase $2 \mathrm{~b}$ - Construction.

- Parallel construction. If there is another project in the area of HU-4, all issues associated with parallel construction projects would need to be addressed. It would be imperative that the costs associated with this project are accounted for separately for any other ongoing work at the plant.

\subsubsection{Contracting Strategy}

The recommended contracting strategy for this project is to utilize a large company in a General Contractor capacity. The general contractor should be able to either self perform or contract the civil, mechanical and instrumentation \& electrical work out. Construction packages are expected to have enough scope detail to make this approach feasible due to the phased approach of the project.

A general contractor that has experience in working with government contracts would be the preferred choice to comply with the foreseen stringent DOE reporting requirements. The Davis Bacon Act Requirements (prevailing wage rates) would be one of the requirements that we would need to ensure is being enforced properly.

The above strategy would apply to all aspects of the project except the plant tie-in work and the substation addition. The tie-in work would be handled by a plant maintenance contractor and the substation addition would be evaluated to determine if it should be contracted thru Praxair directly. 


\section{$2.4 \quad \mathrm{CO}_{2}$ Transport, Delivery, Injection and Geologic Sequestration; MVA of Stored $\mathrm{CO}_{2}$}

\subsection{1 $\quad \mathrm{CO}_{2}$ Transport/Delivery}

A lateral pipeline would be built from Praxair's hydrogen production facility in Texas City to the Green Pipeline owned by Denbury's affiliate or equivalent outlet to connect to Denbury's EOR fields. There are a number of other significant industrial $\mathrm{CO}_{2}$ sources (e.g., other refineries and petrochemical plants) along this lateral pipeline that would enable future aggregation of $\mathrm{CO}_{2}$.

The purpose of the proposed $\mathrm{CO}_{2}$ pipeline "lateral" is to transport 1 million tons per year of anthropogenic $\mathrm{CO}_{2}$ from the Praxair Texas City capture and compression site 8 miles in Galveston County, Texas to Denbury affiliate's existing 24-inch Green Pipeline north of Texas City. The pipeline route will commence within facility boundaries, and for approximately 1 mile, follow a westerly path parallel to existing pipelines in DOW's Texas City facility. Once through DOW's facility the pipeline would traverse in a northerly direction, paralleling existing pipeline corridors for the remaining 7 miles.

The proposed 10-inch diameter lateral is designed to carry $42.5 \mathrm{Mscfd}$ of $\mathrm{CO}_{2}$ with a maximum inlet pressure of $2100 \mathrm{psig}$. The lateral will incorporate the installation of two meter stations with SCADA at each end, one outside of the Praxair facility and one at the tie-in to the Green Pipeline.

Upon definition of the preliminary routing, hydraulic analyses and a fracture propagation study were performed to determine the appropriate pipeline characteristics for the projected flow conditions.

\subsubsection{Preliminary CO2 Injection Site Confirmation}

Please see Appendix A.

\subsubsection{Site-specific MVA options evaluation}

Please see Appendix B

\subsubsection{Draft Risk Assessment and MVA Plan}

Please see Appendix C

\subsubsection{Final MVA plan and detailed budget}

Please see Appendix D 


\section{Section 3. Environmental Impacts and Permits}

\subsection{National Environmental Policy Act (NEPA), Environmental Information Volume}

During Phase 1, Praxair conducted the following activities to prepare the EIV and compliance with NEPA.

1. Detailed Review and Understanding of Federal Regulations: Reviewed the following regulations to have better understanding of EIV process. Communicated with agency's environmental contact, and reviewed available guidance documents on EIV preparation.

- 10 CFR 1021 - National Environmental Policy Act implementing procedures.

- 40 CFR 1501 - NEPA and Agency Planning

- 40 CFR 1502 - Environmental Impact Statement

- 40 CFR 1505 - NEPA and Agency Decision Making

- 40 CFR 1506 - Other Requirements of NEPA

2. Environmental Consultant Selection: Evaluated three consulting companies and selected $\mathrm{CH}_{2} \mathrm{M}$ Hill based on their experience and qualifications for EIV preparation.

3. EIV Preparation: An EIV has been prepared to provide information regarding existing environmental conditions, potential environmental impacts, and mitigative measures associated with the development of a commercial demonstration of advanced technologies that would capture $\mathrm{CO}_{2}$ emissions from an existing hydrogen production facility which provides hydrogen to existing refinery and chemical customers and sequester in underground formations in combination with EOR. The review included a Carbon Capture System (CCS), 7.33-mile $\mathrm{CO}_{2}$ pipeline and associated ancillary equipment (hereafter Pipeline Lateral) and a research monitoring, verification, and accounting (MVA) project at a site in West Hastings Field.

4. The EIV was developed using readily available data as part of a desktop analysis. Field verifications were not conducted; nor were outside agencies consulted. The data provided herein is intended for use by the U.S. Department of Energy (DOE) in accordance with the National Environmental Policy Act (NEPA). As part of this analysis, the preferred CCS, Pipeline Lateral, and MVA locations are presented in the EIV. See Table 1 for Summary of Environmental Impacts. 


\begin{tabular}{|c|c|c|c|}
\hline \multicolumn{4}{|c|}{$\begin{array}{c}\text { Table } 1 \\
\text { Comparison of Impacts of Considered Alternatives }\end{array}$} \\
\hline Resource Area & Proposed Action & Alternative Action & $\begin{array}{l}\text { No Action } \\
\text { Alternative }\end{array}$ \\
\hline Air Quality & $\begin{array}{l}\text { CCS } \\
\text { Project built with DOE funding } \\
\text { would result in a reduction of } \\
\mathrm{CO}_{2} \text { released to the } \\
\text { atmosphere. } \\
\text { Pipeline Lateral } \\
\text { Temporary impacts during } \\
\text { construction include increased } \\
\text { dust and combustion } \\
\text { equipment operations. No } \\
\text { permanent impacts are } \\
\text { anticipated. } \\
\\
\text { MVA } \\
\text { Air impacts will be limited to } \\
\text { temporary emissions from } \\
\text { drilling equipment associated } \\
\text { with well development. }\end{array}$ & $\begin{array}{l}\text { CCS } \\
\text { Project built without DOE } \\
\text { funding would result in a } \\
\text { reduction of } \mathrm{CO}_{2} \text { released to } \\
\text { the atmosphere. } \\
\text { Pipeline Lateral } \\
\text { Temporary impacts } \\
\text { associated with construction } \\
\text { of additional road or rail lines } \\
\text { (if necessary) to } \\
\text { accommodate increased } \\
\text { traffic volume. Permanent } \\
\text { impacts associated with } \\
\text { increased truck or rail related } \\
\text { emissions. } \\
\text { MVA } \\
\text { Air impacts will be limited to } \\
\text { temporary emissions from } \\
\text { drilling equipment associated } \\
\text { with well development. }\end{array}$ & $\begin{array}{l}\text { Permanent impacts } \\
\text { associated with } \\
\text { increased } \mathrm{CO}_{2} \text { due } \\
\text { to lack of } \\
\text { sequestration. }\end{array}$ \\
\hline $\begin{array}{l}\text { Water } \\
\text { Quality/Quantity }\end{array}$ & $\begin{array}{l}\text { CCS } \\
\text { Temporary impacts associated } \\
\text { with erosion from construction } \\
\text { are possible but will be } \\
\text { minimized through BMPs as } \\
\text { part of the SWPPP. Any } \\
\text { industrial discharges will be } \\
\text { handled through the operating } \\
\text { facilities TPDES permit. } \\
\text { Pipeline Lateral } \\
\text { Temporary, localized impacts } \\
\text { during construction } \\
\text { stream/wetland crossings; } \\
\text { Potential releases to streams } \\
\text { during HDD operations; } \\
\text { Surface water withdraws for } \\
\text { hydrostatic testing. } \\
\text { MVA } \\
\text { No anticipated impacts to water } \\
\text { quality. Minor use of water } \\
\text { used for well development. }\end{array}$ & $\begin{array}{l}\text { CCS } \\
\text { Temporary impacts } \\
\text { associated with erosion from } \\
\text { construction are possible but } \\
\text { will be minimized through } \\
\text { BMPs as part of the SWPPP. } \\
\text { Any industrial discharges will } \\
\text { be handled through the } \\
\text { operating facilities TPDES } \\
\text { permit. } \\
\text { Pipeline Lateral } \\
\text { Temporary impacts } \\
\text { associated with construction } \\
\text { of additional roads or rail lines } \\
\text { (if necessary) to } \\
\text { accommodate increased } \\
\text { traffic volume. } \\
\text { MVA } \\
\text { No anticipated impacts to } \\
\text { water quality. Minor use of } \\
\text { water used for well } \\
\text { development. }\end{array}$ & No Impacts. \\
\hline
\end{tabular}




\begin{tabular}{|c|c|c|c|}
\hline \multicolumn{4}{|c|}{$\begin{array}{c}\text { Table } 1 \\
\text { Comparison of Impacts of Considered Alternatives }\end{array}$} \\
\hline Resource Area & Proposed Action & Alternative Action & $\begin{array}{l}\text { No Action } \\
\text { Alternative }\end{array}$ \\
\hline $\begin{array}{l}\text { Solid Waste } \\
\text { Disposal }\end{array}$ & $\begin{array}{l}\text { CCS } \\
\text { General construction debris will } \\
\text { be handled through the } \\
\text { facilities waste management } \\
\text { plan. No waste associated with } \\
\text { operation is anticipated. } \\
\text { Pipeline Lateral } \\
\text { Temporary construction } \\
\text { impacts associated with land } \\
\text { clearing, construction supply } \\
\text { packing materials, and general } \\
\text { refuse; Negligible solid waste } \\
\text { generated during operations } \\
\text { and maintenance activities. } \\
\text { MVA } \\
\text { Minimal amounts of drilling } \\
\text { mud will be generated during } \\
\text { construction and will be land } \\
\text { farmed onsite. No solid waste } \\
\text { generated during operation is } \\
\text { anticipated. }\end{array}$ & $\begin{array}{l}\text { CCS } \\
\text { General construction debris } \\
\text { will be handled through the } \\
\text { facilities waste management } \\
\text { plan. No waste associated } \\
\text { with operation is anticipated. } \\
\text { Pipeline Lateral } \\
\text { Temporary impacts during } \\
\text { construction of additional } \\
\text { roads or rail lines (if } \\
\text { necessary) to accommodate } \\
\text { increased traffic volume. } \\
\text { Minimal permanent impacts } \\
\text { associated with general } \\
\text { refuse from truck or rail staff. } \\
\text { MVA } \\
\text { Minimal amounts of drilling } \\
\text { mud will be generated during } \\
\text { construction and will be land } \\
\text { farmed onsite. No solid } \\
\text { waste generated during } \\
\text { operation is anticipated. }\end{array}$ & No Impacts. \\
\hline \multirow[t]{2}{*}{ Land Use } & $\begin{array}{l}\text { CCS } \\
\text { The CCS will be located within } \\
\text { the operating facility; therefore } \\
\text { no permanent impacts to land } \\
\text { use are anticipated. } \\
\text { Pipeline Lateral } \\
\text { Temporary impacts to } 95 \text { foot } \\
\text { wide ROW during construction; } \\
\text { Permanent conversion of some } \\
\text { land types to } 50 \text { foot wide } \\
\text { ROW for operations and } \\
\text { maintenance activities. }\end{array}$ & $\begin{array}{l}\text { CCS } \\
\text { The CCS will be located } \\
\text { within the operating facility; } \\
\text { therefore no permanent } \\
\text { impacts to land use are } \\
\text { anticipated. } \\
\text { Pipeline Lateral } \\
\text { Potential permanent } \\
\text { conversion of land to } \\
\text { additional road or rail lines to } \\
\text { accommodate increased } \\
\text { traffic volume and access to } \\
\mathrm{CO}_{2} \text { delivery point. }\end{array}$ & No Impacts. \\
\hline & $\begin{array}{l}\text { MVA } \\
\text { The area is currently an } \\
\text { operating oil and gas field and } \\
\text { no change in land use is } \\
\text { anticipated. }\end{array}$ & $\begin{array}{l}\text { MVA } \\
\text { The area is currently an } \\
\text { operating oil and gas field } \\
\text { and no change in land use is } \\
\text { anticipated. }\end{array}$ & \\
\hline Noise & $\begin{array}{l}\frac{\mathrm{CCS}}{\text { Temporary increase in noise }} \\
\text { levels associated with } \\
\text { construction. }\end{array}$ & $\begin{array}{l}\frac{\mathrm{CCS}}{\text { Temporary increase in noise }} \\
\text { levels associated with } \\
\text { construction. }\end{array}$ & No Impacts. \\
\hline
\end{tabular}




\begin{tabular}{|c|c|c|c|}
\hline \multicolumn{4}{|c|}{$\begin{array}{c}\text { Table } 1 \\
\text { Comparison of Impacts of Considered Alternatives }\end{array}$} \\
\hline Resource Area & Proposed Action & Alternative Action & $\begin{array}{l}\text { No Action } \\
\text { Alternative }\end{array}$ \\
\hline & $\begin{array}{l}\text { Pipeline Lateral } \\
\text { Temporary noise impacts } \\
\text { during construction; Negligible } \\
\text { permanent impacts during } \\
\text { operations and maintenance. } \\
\text { MVA } \\
\text { Temporary increase in noise } \\
\text { levels associated with } \\
\text { construction. }\end{array}$ & $\begin{array}{l}\text { Pipeline Lateral } \\
\text { Temporary impacts } \\
\text { associated with construction } \\
\text { of additional road or rail lines } \\
\text { (if necessary) to } \\
\text { accommodate increased } \\
\text { traffic volume. Permanent } \\
\text { noise impacts associated with } \\
\text { increased truck or rail traffic } \\
\text { volume. } \\
\text { MVA } \\
\text { Temporary increase in noise } \\
\text { levels associated with } \\
\text { construction. }\end{array}$ & \\
\hline $\begin{array}{l}\text { Floodplains and } \\
\text { Wetlands }\end{array}$ & $\begin{array}{l}\text { CCS } \\
\text { The CCS would not be located } \\
\text { within a floodplain or wetland } \\
\text { therefore no impacts are } \\
\text { anticipated. } \\
\text { Pipeline Lateral } \\
\text { Temporary, localized impacts } \\
\text { to floodplain and during } \\
\text { construction stream and } \\
\text { wetland crossings. } \\
\\
\text { MVA } \\
\text { The MVA would not be located } \\
\text { within a floodplain or wetland } \\
\text { therefore no impacts are } \\
\text { anticipated. }\end{array}$ & $\begin{array}{l}\text { CCS } \\
\text { The CCS would not be } \\
\text { located within a floodplain or } \\
\text { wetland therefore no impacts } \\
\text { are anticipated. } \\
\text { Pipeline Lateral } \\
\text { Permanent impacts } \\
\text { associated with construction } \\
\text { of additional roads or rail lines } \\
\text { that may be necessary to } \\
\text { accommodate increased } \\
\text { traffic and access to } \mathrm{CO}_{2} \\
\text { delivery point. } \\
\text { MVA } \\
\text { The MVA would not be } \\
\text { located within a floodplain or } \\
\text { wetland therefore no impacts } \\
\text { are anticipated. }\end{array}$ & No Impacts. \\
\hline $\begin{array}{l}\text { Native } \\
\text { American Tribal } \\
\text { and Religious } \\
\text { Practices }\end{array}$ & $\begin{array}{l}\text { CCS } \\
\text { The CCS will not be located on } \\
\text { Native American tribal lands } \\
\text { therefore no impacts are } \\
\text { anticipated. }\end{array}$ & $\begin{array}{l}\text { CCS } \\
\text { The CCS will not be located } \\
\text { on Native American tribal } \\
\text { lands therefore no impacts } \\
\text { are anticipated. }\end{array}$ & No Impacts. \\
\hline
\end{tabular}




\begin{tabular}{|c|c|c|c|}
\hline \multicolumn{4}{|c|}{$\begin{array}{c}\text { Table } 1 \\
\text { Comparison of Impacts of Considered Alternatives }\end{array}$} \\
\hline Resource Area & Proposed Action & Alternative Action & $\begin{array}{l}\text { No Action } \\
\text { Alternative }\end{array}$ \\
\hline & $\begin{array}{l}\text { Pipeline Lateral } \\
\text { The pipeline lateral will not be } \\
\text { located on Native American } \\
\text { tribal lands therefore no } \\
\text { impacts are anticipated. } \\
\text { MVA } \\
\text { The MVA will not be located on } \\
\text { Native American tribal lands } \\
\text { therefore no impacts are } \\
\text { anticipated. }\end{array}$ & $\begin{array}{l}\text { Pipeline Lateral } \\
\text { Additional roads or rail lines } \\
\text { that may be necessary to } \\
\text { accommodate increased } \\
\text { traffic and access to the } \mathrm{CO}_{2} \\
\text { delivery point will not be } \\
\text { located on Native American } \\
\text { lands therefore no impacts } \\
\text { are anticipated. } \\
\text { MVA } \\
\text { The MVA will not be located } \\
\text { on Native American tribal } \\
\text { lands therefore no impacts } \\
\text { are anticipated. }\end{array}$ & \\
\hline Historic & $\begin{array}{l}\text { CCS } \\
\text { No listed historic sites are } \\
\text { located in the area the CCS will } \\
\text { be located therefore no impacts } \\
\text { are anticipated. } \\
\text { Pipeline Lateral } \\
\text { There are no known historic } \\
\text { sites along the pipeline route } \\
\text { therefore no impacts are } \\
\text { anticipated. } \\
\text { MVA } \\
\text { There are no known historic } \\
\text { sites at the MVA location } \\
\text { therefore no impacts are } \\
\text { anticipated. }\end{array}$ & $\begin{array}{l}\text { CCS } \\
\text { No listed historic sites are } \\
\text { located in the area the CCS } \\
\text { will be located therefore no } \\
\text { impacts are anticipated. } \\
\text { Pipeline Lateral } \\
\text { There are no known historic } \\
\text { sites along the propose road } \\
\text { or rail route to accommodate } \\
\text { additional traffic therefore no } \\
\text { impacts are anticipated. } \\
\text { MVA } \\
\text { There are no known historic } \\
\text { sites at the MVA location } \\
\text { therefore no impacts are } \\
\text { anticipated. }\end{array}$ & No Impacts. \\
\hline Ecological & $\begin{array}{l}\text { CCS } \\
\text { The CCS system will be on a } \\
\text { previously disturbed area } \\
\text { inside the operating facility of } \\
\text { the BP plant and therefore no } \\
\text { permanent impacts to native } \\
\text { habitats or species are } \\
\text { anticipated. }\end{array}$ & $\begin{array}{l}\text { CCS } \\
\text { The CCS system will be on a } \\
\text { previously disturbed area } \\
\text { inside the operating facility of } \\
\text { the BP plant and therefore no } \\
\text { permanent impacts to native } \\
\text { habitats or species are } \\
\text { anticipated. }\end{array}$ & No Impacts. \\
\hline
\end{tabular}




\begin{tabular}{|c|c|c|c|}
\hline \multicolumn{4}{|c|}{$\begin{array}{c}\text { Table } 1 \\
\text { Comparison of Impacts of Considered Alternatives }\end{array}$} \\
\hline Resource Area & Proposed Action & Alternative Action & $\begin{array}{l}\text { No Action } \\
\text { Alternative }\end{array}$ \\
\hline & $\begin{array}{l}\text { Pipeline Lateral } \\
\text { Temporary impacts to } \\
\text { vegetation and displacement of } \\
\text { wildlife during construction; } 50 \\
\text { foot wide permanent ROW will } \\
\text { be maintained for operations } \\
\text { and maintenance activities; } \\
\text { Permanent impacts to wildlife } \\
\text { are anticipated to be minimal. } \\
\\
\text { MVA } \\
\text { Minor temporary impacts to } \\
\text { vegetation may occur during } \\
\text { construction but no permanent } \\
\text { impacts are anticipated. }\end{array}$ & $\begin{array}{l}\text { Pipeline Lateral } \\
\text { Temporary impacts during } \\
\text { construction of additional } \\
\text { roads or rail lines (if } \\
\text { necessary) to accommodate } \\
\text { increased traffic volume. } \\
\text { Permanent impacts } \\
\text { associated with increased } \\
\text { traffic volume and permanent } \\
\text { conversion of land to roads } \\
\text { and rail lines (if necessary). } \\
\text { MVA } \\
\text { Minor temporary impacts to } \\
\text { vegetation may occur during } \\
\text { construction but no } \\
\text { permanent impacts are } \\
\text { anticipated. }\end{array}$ & \\
\hline Socioeconomics & $\begin{array}{l}\frac{\text { CCS }}{120 \text { construction jobs created }} \\
\text { for up to a year. } \\
\frac{\text { Pipeline Lateral }}{490 \text { construction jobs created. }} \\
\text { MVA } \\
\text { Temporary increase in jobs } \\
\text { associated with construction. }\end{array}$ & $\begin{array}{l}\frac{C C S}{120} \text { construction jobs created } \\
\text { for up to a year. } \\
\text { Pipeline Lateral } \\
\text { Increase in jobs to construct } \\
\text { the additional roads and/or } \\
\text { rail line needed. } \\
\text { MVA } \\
\text { Temporary increase in jobs } \\
\text { associated with construction. }\end{array}$ & No Impacts. \\
\hline
\end{tabular}

\subsection{Permits and Other Regulatory Authorizations}

The CCS project site is located in an ozone non-attainment area with severe classification. The CCS portion of the Project is expected to significantly reduce $\mathrm{CO}_{2}$ emissions and small amounts of $\mathrm{CH} 4$ and $\mathrm{CO}$ emissions from trace amounts of these compounds in the syngas.

Praxair is a major facility for VOC, NOx, $\mathrm{SO}_{2}, \mathrm{PM}_{10}, \mathrm{CO}$, and HAPs, and thus has a Title $\mathrm{V}$ operating permit (Permit No. O2657). Praxair would update their Title $\mathrm{V}$ permit as required with the CCS project changes. Praxair must continue to comply with the regulatory requirements listed in their Title $\mathrm{V}$ permit.

Control of air pollution by permits (30 TAC Chapter 116) - Praxair is currently operating under TCEQ flexible permit. Praxair would obtain permit amendment to include the changes.

Water used during operation of the CCS would be supplied by the BP Texas City Refinery using its existing on-site water distribution system. The existing on-site cooling tower and pumps would be upgraded to provide water for the CCS. An additional cooling water pump to the cooling tower to provide the incremental cooling water may be required (Praxair 2009). 
If required, effluent from the CCS would be treated with existing or expanded on-site treatment facilities at the Refinery. Discharges from the site would be accommodated through existing infrastructure and approved (or amended, if required) TPDES discharge permits (Praxair 2009). Discharge quality would conform to constituent limits identified in the TPDES permit. No significant change in water use and effluent discharge volume or quality is anticipated.

Praxair would comply with the General Construction Storm Water Permit requirements to minimize storm water pollution during the construction activity.

Applicable Permits for the Proposed Action are summarized in Table 2.

\begin{tabular}{|c|c|c|c|}
\hline \multicolumn{4}{|c|}{$\begin{array}{l}\text { Applicable Permits for the Proposed Action } \\
\text { Praxair Texas City Carbon Capture, Transport, and Sequestration Project }\end{array}$} \\
\hline Permit/Approval & $\begin{array}{l}\text { Administering } \\
\text { Agency }\end{array}$ & $\begin{array}{c}\text { Anticipated time for } \\
\text { Permit/Clearance } \\
\text { Approval }\end{array}$ & Comment \\
\hline $\begin{array}{l}\text { Section 404/10 } \\
\text { Compliance } \\
\text { (Nationwide Permit } \\
\text { [NWP] 12) }\end{array}$ & $\begin{array}{l}\text { USACE New } \\
\text { Orleans District }\end{array}$ & 3 months & $\begin{array}{l}\text { Assumes standard Nationwide } \\
\text { Program timelines would apply. } \\
\text { Requires } 30 \text {-day review period to } \\
\text { determine if PCN application is } \\
\text { complete and } 45 \text { days to review } \\
\text { and issue permit. } \\
\text { Allows for early submittal of } \\
\text { USFWS, and U.S. Department of } \\
\text { Agriculture (USDA) applications } \\
\text { and their clearances during the } \\
\text { USACE review period. }\end{array}$ \\
\hline $\begin{array}{l}\text { Threatened and } \\
\text { Endangered Species } \\
\text { Consultation }\end{array}$ & $\begin{array}{l}\text { USFWS, } \\
\text { Lafayette } \\
\text { Ecological } \\
\text { Services Field } \\
\text { Office }\end{array}$ & 2 months & $\begin{array}{l}\text { Assumes } 2 \text { months for USFWS to } \\
\text { review and issue clearance as } \\
\text { part of the pre-survey NEPA } \\
\text { agency consultation. Does not } \\
\text { include time if formal Section } 7 \\
\text { consultation is required. }\end{array}$ \\
\hline $\begin{array}{l}\text { Approval for crossing } \\
\text { conservation } \\
\text { easements, } \\
\text { Conservation } \\
\text { Restoration Program } \\
\text { lands, Prime } \\
\text { Farmland, and } \\
\text { Wetland Restoration } \\
\text { Program lands (if } \\
\text { necessary) }\end{array}$ & USDA, NRCS & 2 months & $\begin{array}{l}\text { Assumes } 2 \text { months for NRCS to } \\
\text { review and issue clearance given } \\
\text { the pre-application/pre-survey } \\
\text { consultations. }\end{array}$ \\
\hline $\begin{array}{l}\text { Threatened and } \\
\text { Endangered Species } \\
\text { Consultation }\end{array}$ & TPWD & 3 months & $\begin{array}{l}\text { Assumes } 3 \text { months for TPWD to } \\
\text { review and issue clearance given } \\
\text { the pre-application/pre-survey } \\
\text { consultations. }\end{array}$ \\
\hline
\end{tabular}




\begin{tabular}{|c|c|c|c|}
\hline \multicolumn{4}{|c|}{$\begin{array}{l}\text { Applicable Permits for the Proposed Action } \\
\text { Praxair Texas City Carbon Capture, Transport, and Sequestration Project }\end{array}$} \\
\hline Permit/Approval & $\begin{array}{l}\text { Administering } \\
\text { Agency }\end{array}$ & $\begin{array}{l}\text { Anticipated time for } \\
\text { Permit/Clearance } \\
\text { Approval }\end{array}$ & Comment \\
\hline $\begin{array}{l}\text { Clean Water Act } \\
\text { Section } 402 \\
\text { stormwater } \\
\text { discharges }\end{array}$ & TCEQ & $\begin{array}{l}\text { Provisional coverage } \\
\text { begins immediately } \\
\text { if applied on-line, } 7 \\
\text { days if applied by } \\
\text { paper copy }\end{array}$ & $\begin{array}{l}\text { Required for stormwater } \\
\text { discharges to waters of the U.S. } \\
\text { EPA has tasked TCEQ with } \\
\text { implementation of the "General } \\
\text { Construction Permit" that covers } \\
\text { most construction jobs. This } \\
\text { requires the drafting of SWPPP } \\
\text { and SPCC plans. }\end{array}$ \\
\hline $\begin{array}{l}\text { Coastal Zone Federal } \\
\text { Consistency Review }\end{array}$ & Texas CCC & 3 months & $\begin{array}{l}\text { Authorized under Section } 306 \text { of } \\
\text { the Federal Coastal Zone } \\
\text { Management Act of } 1972\end{array}$ \\
\hline $\begin{array}{l}\text { Section } 401 \text { Water } \\
\text { Quality Certification } \\
\text { (joint application } \\
\text { through USACE } \\
\text { Section } 404 \text { permit) }\end{array}$ & TCEQ & 3 months & $\begin{array}{l}\text { Assumes joint application with } \\
\text { the USACE Section } 404 \\
\text { application and timeline } \\
\text { assumptions. }\end{array}$ \\
\hline $\begin{array}{l}\text { Hydrostatic Test } \\
\text { Water Discharge } \\
\text { Permit (TXG670000) }\end{array}$ & TCEQ & Unknown & $\begin{array}{l}\text { NOI to be filed prior to Project } \\
\text { implementation. }\end{array}$ \\
\hline $\begin{array}{l}\text { NPDES Construction } \\
\text { Storm Water General } \\
\text { Permit (TXR150000) }\end{array}$ & TCEQ & $\begin{array}{l}\text { NOI submitted at } \\
\text { least } 48 \text { hours before } \\
\text { construction begins. }\end{array}$ & $\begin{array}{l}\text { Construction projects that disturb } \\
\text { one or more acres must be } \\
\text { covered under the general } \\
\text { construction permit. Prepare a } \\
\text { NOI and BMP Plan for } \\
\text { Construction. } \\
\text { Only requires that SWPPP/SPCC } \\
\text { plans be drafted and kept on site } \\
\text { and construction activities follow } \\
\text { all general conditions of the } \\
\text { permit. }\end{array}$ \\
\hline SPCC Plan & TCEQ, EPA & Unknown & $\begin{array}{l}\text { The SPCC is a federal } \\
\text { requirement ( } 40 \text { CFR 112) for } \\
\text { facilities that store specific } \\
\text { amounts of petroleum products. } \\
\text { Praxair already has an SPCC } \\
\text { plan and would amend the } \\
\text { current plan to include the CCS. }\end{array}$ \\
\hline
\end{tabular}




\begin{tabular}{|c|c|c|c|}
\hline \multicolumn{4}{|c|}{ Table 2} \\
\hline Permit/Approval & $\begin{array}{l}\text { Administering } \\
\text { Agency }\end{array}$ & $\begin{array}{c}\text { Anticipated time for } \\
\text { Permit/Clearance } \\
\text { Approval }\end{array}$ & Comment \\
\hline $\begin{array}{l}\text { Section } 106 \text { of } \\
\text { National Historic } \\
\text { Preservation Act of } \\
1966 \text {, as amended } \\
\text { (16 USC } 470 \text { et seq.), } \\
\text { and Advisory Council } \\
\text { Regulations on the } \\
\text { Protection of Historic } \\
\text { and Cultural } \\
\text { Properties, as } \\
\text { amended } \\
\text { (36 CFR 800) }\end{array}$ & $\begin{array}{l}\text { Texas Historical } \\
\text { Commission } \\
\text { (Texas SHPO) }\end{array}$ & 3 month & $\begin{array}{l}\text { Under Section } 106 \text { of the } \\
\text { National Historic Preservation Act } \\
\text { of } 1966 \text { and under federal } \\
\text { regulations governing the } \\
\text { protection of historic and cultural } \\
\text { resources, federal and other } \\
\text { governmental agencies to whom } \\
\text { federal authority has been } \\
\text { delegated must avoid } \\
\text { undertakings that adversely affect } \\
\text { properties included in or eligible } \\
\text { for the NRHP. Pre-work } \\
\text { surveying and reporting would be } \\
\text { site dependent and would be } \\
\text { required before consultation if } \\
\text { consultation is determined to be } \\
\text { required. }\end{array}$ \\
\hline ROW Encroachment & TxDOT & 2 to 4 months & $\begin{array}{l}\text { If new access is required from a } \\
\text { state roadway(s), an } \\
\text { encroachment permit would likely } \\
\text { be required from TxDOT. }\end{array}$ \\
\hline Transport Permit & TxDOT & Unknown & $\begin{array}{l}\text { Transportation of loads on state } \\
\text { highways that exceed established } \\
\text { size or weight limits requires a } \\
\text { permit from the TxDOT. } \\
\text { A special permit is required if the } \\
\text { load is going to use the entire } \\
\text { roadway, necessitating road } \\
\text { closure. } \\
\text { The construction or transportation } \\
\text { contractor typically obtains this } \\
\text { permit. }\end{array}$ \\
\hline Class II UIC permit & $\begin{array}{l}\text { Texas Railroad } \\
\text { Commission }\end{array}$ & 45 days & $\begin{array}{l}\text { Required permit to drill, deepen, } \\
\text { reenter, or plug back any well to } \\
\text { be used for MVA purposes. } \\
\text { Covers wells used for injecting } \\
\text { fluids, including wastewater. }\end{array}$ \\
\hline $\begin{array}{l}\text { Amendment to the } \\
\text { current } \\
\text { Praxair Flexible Air } \\
\text { Permit }\end{array}$ & TCEQ & 270 days & No Federal NSR Permit \\
\hline Revised Title V & TCEQ & 330 days & No Federal NSR Permit \\
\hline
\end{tabular}




\section{Section 4. Prospectus for Phase 2 Project}

As a result of the cost and risk analysis conducted during Phase 1, Praxair has decided not to pursue funding for Phase 2. We have concluded that the project costs and integration risks at Texas City are not commensurate with the potential benefits of the project at this time. During the Phase 1 detailed cost estimate, project costs increased substantially from the previous estimate.

Furthermore, the detailed risk assessment identified integration risks that could potentially impact the steam methane reformer operation. The integration issues arise since the process would remove $\mathrm{CO}_{2}$ from an existing process stream in the plant as opposed to removing it from a flue gas stream which would have had minimal impact on the commercial operation. While the Phase 1 work identified ways to mitigate these integration risks satisfactorily from an operational perspective, the associated costs and potential schedule impacts contributed to the decision not to proceed to Phase 2.

Praxair is demonstrating the VPSA $\mathrm{CO}_{2}$ technology on a commercial project that is being constructed at a Praxair owned facility to produce food and beverage grade $\mathrm{CO}_{2}$. By demonstrating the VPSA technology elsewhere, this capture technology will be ready once a commercially viable market for carbon capture and sequestration develops.

\section{Graphical Materials List}

Plot Layout for $\mathrm{CO}_{2}$ Capture Facility (located at end of report).

\section{Appendices}

Appendix A: Preliminary $\mathrm{CO}_{2}$ Injection Site Confirmation

Appendix B: Site-Specific MVA Options Evaluation

Appendix C: Draft Risk Assessment and MVA Plan

Appendix D: Final MVA Plan And Detailed Budget

\section{List of Acronyms and Abbreviations}

$\begin{array}{ll}\text { Abbreviation } & \text { Definition } \\ \text { AIG } & \text { Ammonia Injection Grid } \\ \text { CCS } & \text { Carbon Capture and Sequestration } \\ \text { CFD } & \text { Computational Fluid Dynamics } \\ \text { CHWP } & \text { Construction Hazard Work Permit } \\ \text { CM } & \text { Construction Manager } \\ \text { EA } & \text { Environmental Assessment } \\ \text { EIS } & \text { Environmental Impact Study } \\ \text { EIV } & \text { Environmental Information Volume } \\ \text { EOR } & \text { Enhanced Oil Recovery } \\ \text { FCM } & \text { Field Construction Manager } \\ \text { FEL } & \text { Front End Loading } \\ \text { GCCC } & \text { Gulf Coast Carbon Center (at Bureau of Economic Geology at Austin) } \\ \text { HAZID } & \text { Hazard Identification Study } \\ \text { HCPV } & \text { Hydrocarbon Pore Volume } \\ \text { HWP } & \text { Hazardous Work Permit } \\ \text { HU\# } & \text { Hydrogen Units (current and past) at Texas City (Site of } \mathrm{CO}_{2} \text { capture) }\end{array}$




\begin{tabular}{|c|c|}
\hline ICCS & Industrial Carbon capture and sequestration \\
\hline ISBL & Inside Battery Limit \\
\hline LHV & Lower Heating Value \\
\hline Mscfd & Million standard cubic feet per day \\
\hline TPDc & tons per day of contained component \\
\hline MTPY & Million tons per year \\
\hline MVA & Monitoring, Verification and Accounting of Stored $\mathrm{CO}_{2}$ \\
\hline NEPA & National Environmental Policy Act \\
\hline OOIP & Original oil in place \\
\hline OSBL & Outside Battery Limit \\
\hline OSHA & Occupational Safety and Health Administration \\
\hline PFT & Perfluorocarbon tracer \\
\hline PHA & Process Hazard Analysis \\
\hline PPE & Personal Protective Equipment \\
\hline PMP & Project Management Plan \\
\hline$P \& A$ & Plugged and Abandoned \\
\hline PSA & Pressure Swing Adsorption \\
\hline psia & pounds per square inch (absolute) \\
\hline PSM & Process Safety Management \\
\hline QA/QC & Quality Assurance and Quality Control \\
\hline RCSP & DOE's Regional Carbon Sequestration Partnership \\
\hline ROW & Right of Way \\
\hline S\&ES & Safety and Environmental Services \\
\hline SACROC & Scurry Area Canyon Reef Operators Committee \\
\hline SCR & Selective Catalytic Reduction \\
\hline SECARB & Southeast Regional Carbon Sequestration partnership \\
\hline SMR & Steam Methane Reformers (Hydrogen Plant) \\
\hline SMP & Standard Maintenance Procedure \\
\hline SOP & Standard Operating Procedure \\
\hline SSSP & Site Specific Safety Plan \\
\hline SWP & Southwest Partnership \\
\hline syngas & Synthesis Gas (contains $\mathrm{H}_{2}, \mathrm{CO}, \mathrm{CO}_{2}, \mathrm{~N}_{2}$ and Methane) \\
\hline TPDc & Ton per day contained \\
\hline TXRRC & Texas Railroad Commission \\
\hline UA & Heat Transfer Coefficient * Area of Heat Exchanger \\
\hline USPTO & United States Patent Office \\
\hline VPSA & Vacuum Pressure Swing Adsorption \\
\hline WHR & Waste Heat Recovery \\
\hline
\end{tabular}




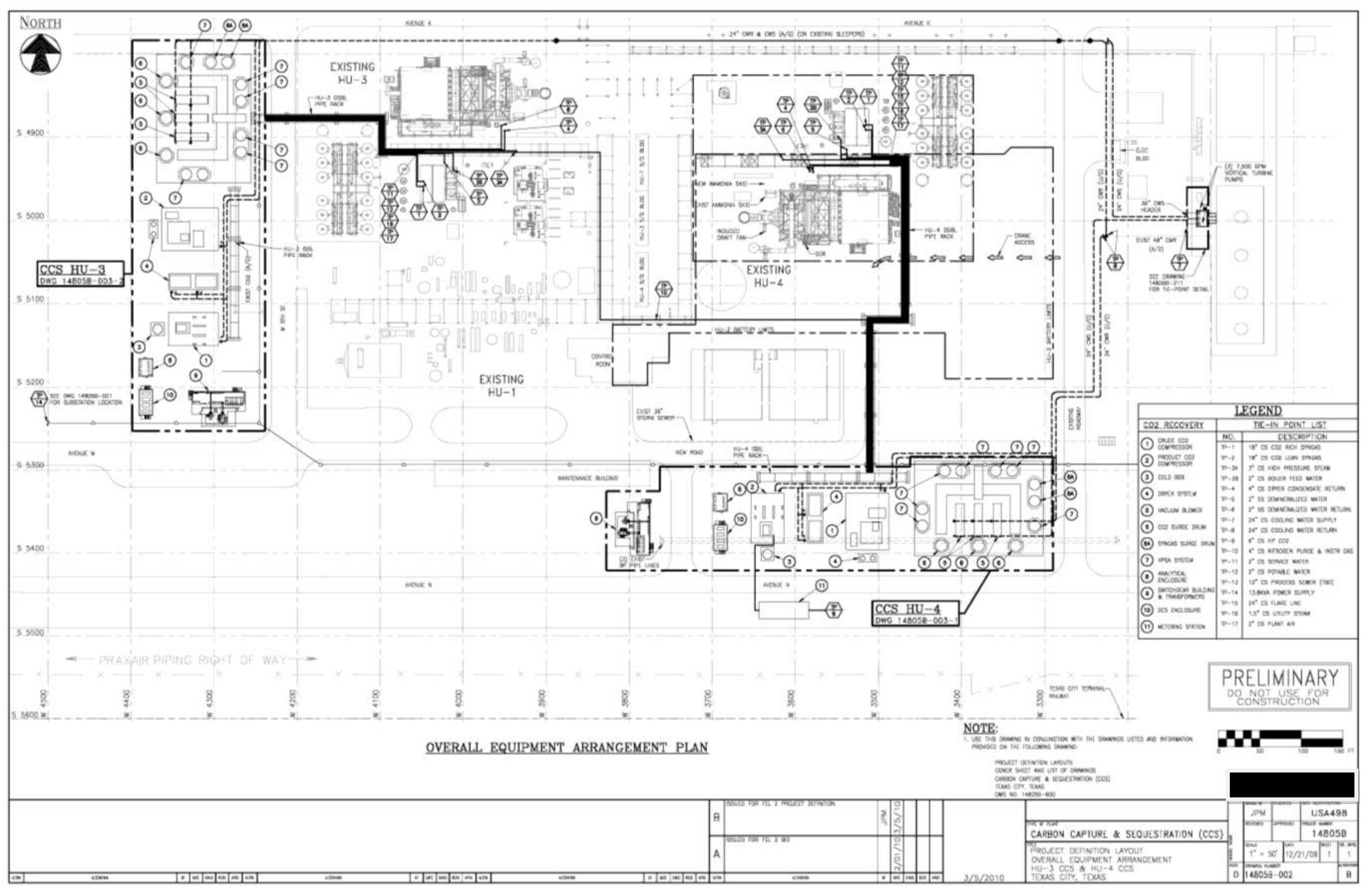




\section{Denbury - Report to Susan Hovorka of BEG on Preliminary EOR} Development at West Hasting Field Unit Fault Block B and C for FOA 15

Report Type:

Report number:

Report title:

Completion Date:

Report Issue Date:

Submitting Organization:
Report and documentation of milestone completion C5.2.2

Preliminary $\mathrm{CO}_{2}$ Injection Site Confirmation

February 26, 2010

April 13, 2010

Steve Upp, Darrell Davis \& Trevor Richards

Denbury Resources Inc.

Plano, Texas 
Phase I Task C5.2.2

Preliminary $\mathrm{CO}_{2}$ Injection Site Confirmation West Hastings Field Unit Fault Block B and C

Prepared for:

Susuan Hovorka of Gulf Coast Carbon Center

Report by Denbury Resources

April 13, 2010

Denbury Resources

5100 Tennyson Pkwy, Suite 200

Plano, Texas 75024 


\section{Table of Contents}

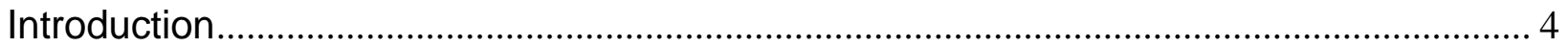

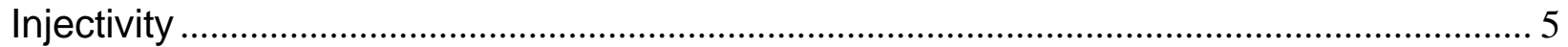

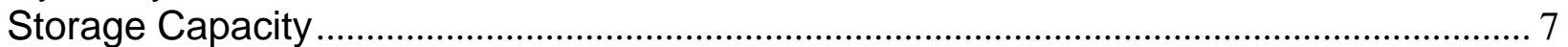

Pattern Selection - Upper Frio................................................................................... 9

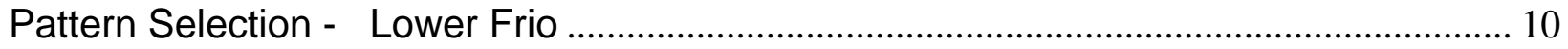

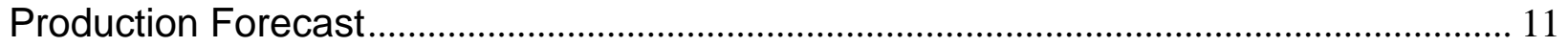

Projected Well Classification and Quantity ................................................................... 14

\section{Figures}

Figure 1. Hastings field Locator Map ................................................................................ 4

Figure 2. Development plan of $\mathrm{CO}_{2}$ flood in West Hastings Field .................................... 4

Figure 3. Stratigraphic Column for Texas and Louisiana Deposits.................................... 5

Figure 4. Top of Structure Map - Hastings Frio Reservoir ................................................ 6

Figure 5. Type Log for West Hastings Fault Block B \& C ................................................. 8

Figure 6. Upper Frio - Fault Blocks B \& C Development .................................................. 10

Figure 7. Lower Frio - Fault Blocks B \& C Development ................................................. 11

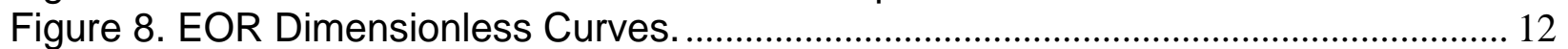

Figure 9. Projected $\mathrm{CO}_{2}$ Volumes ................................................................................. 13

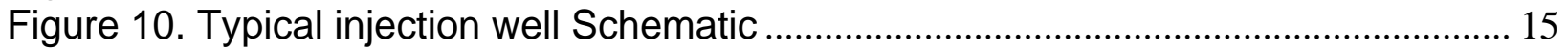

\section{Tables}

Table 1. Field Storage Capacity (Fault Blocks B \& C) ...................................................... 7

Table 2. Results of core-based permeability form fault block A. ..................................... 9

Table 3. CO2 Flood Pattern Size (Fault Blocks B \& C) ....................................................... 12

Table 4. Anticipated Hastings Fault Block B \& C Development Schedule......................... 14 


\section{Introduction}

The West Hastings Field is a planned $\mathrm{CO}_{2}$ EOR project in the Frio formation (figure 1). $\mathrm{CO}_{2}$ injection is scheduled to begin during December, 2010 into the northernmost Fault Block A (figure 2) using naturally occurring $\mathrm{CO}_{2}$ from Denbury's Jackson Dome $\mathrm{CO}_{2}$ supply (Norphlet and Smackover reservoirs). To supplement this naturally occurring $\mathrm{CO}_{2}$ supply, Denbury will utilize anthropogenic $\quad \mathrm{CO}_{2} \quad\left(\mathrm{ACO}_{2}\right)$ supplies to meet its $\mathrm{CO}_{2}$ requirements. It is anticipated that $\mathrm{ACO}_{2}$ will be available for development of Fault Blocks B \& C at Hastings beginning 2013, therefore a preliminary design has been made and estimates of the $\mathrm{CO}_{2}$ storage capacity for the reservoir determined. Information

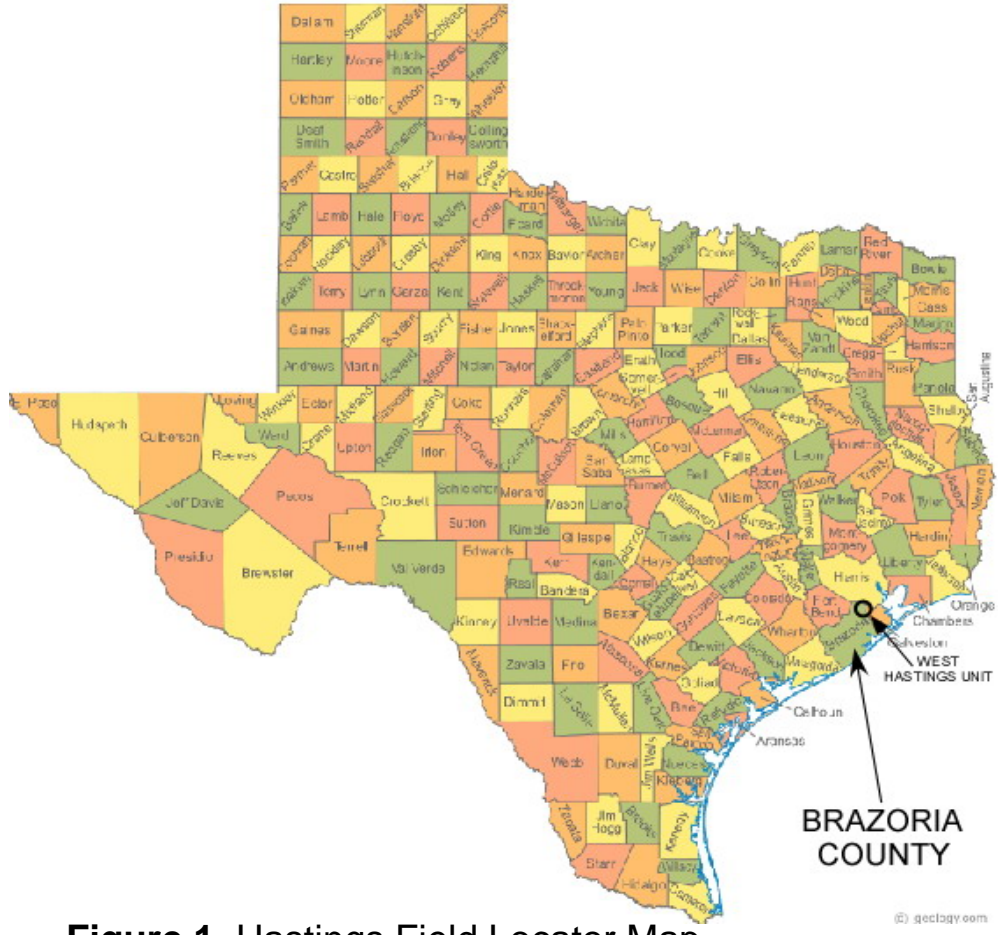

Figure 1. Hastings Field Locator Map gained from actual injection into Fault Block A will be utilized to finalize the Fault Blocks B \& C design during 2011-2012, however this will not dramatically impact the pore volume available for $\mathrm{CO}_{2}$ storage.

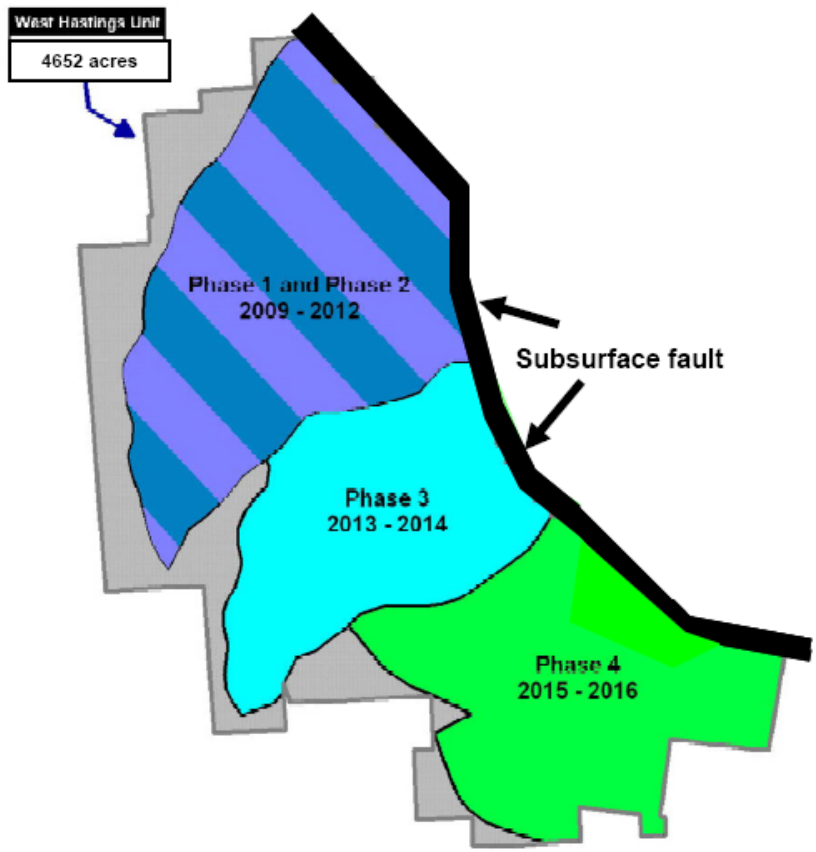

Figure 2. Development plan of $\mathrm{CO}_{2}$ flood in West Hastings Field 
Figure 3. Stratigraphic Column for Texas and Louisiana Deposits

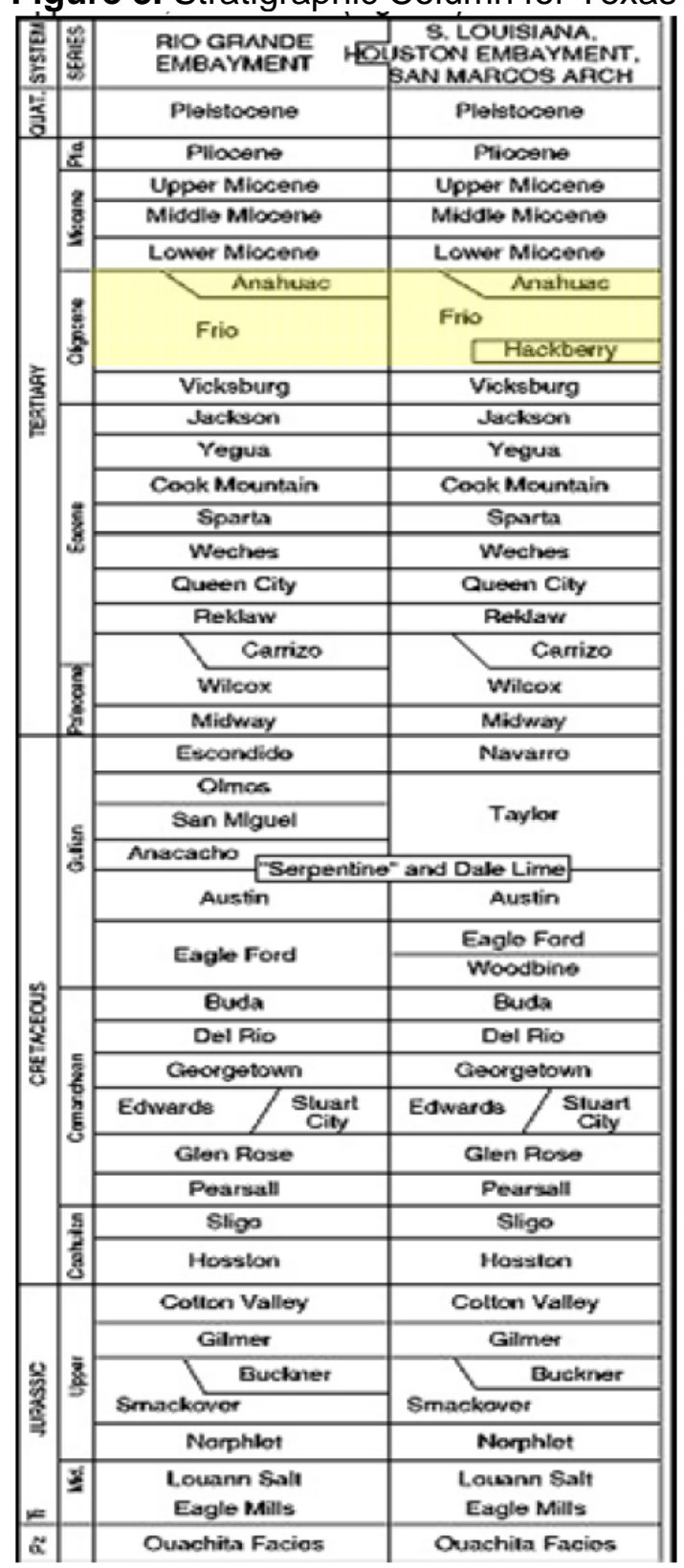

\section{Injectivity}

The Frio Formation of West Hastings Field is well characterized as an injection zone, and sufficient data is currently available to confirm confinement, injectivity, and storage capacity. The Anahuac Formation provides confinement at the top of the reservoir (Figure 3). The base of the Frio Formation is defined by additional shale-sandstone sequences. Multiple sands in both the upper and lower Frio formation will be flooded as part of the Fault Block B and C development plan. In addition, the reservoir is partly compartmentalized by cross faults (Figure 4). 
Figure 4. Top of Structure Map - Hastings Frio Reservoir

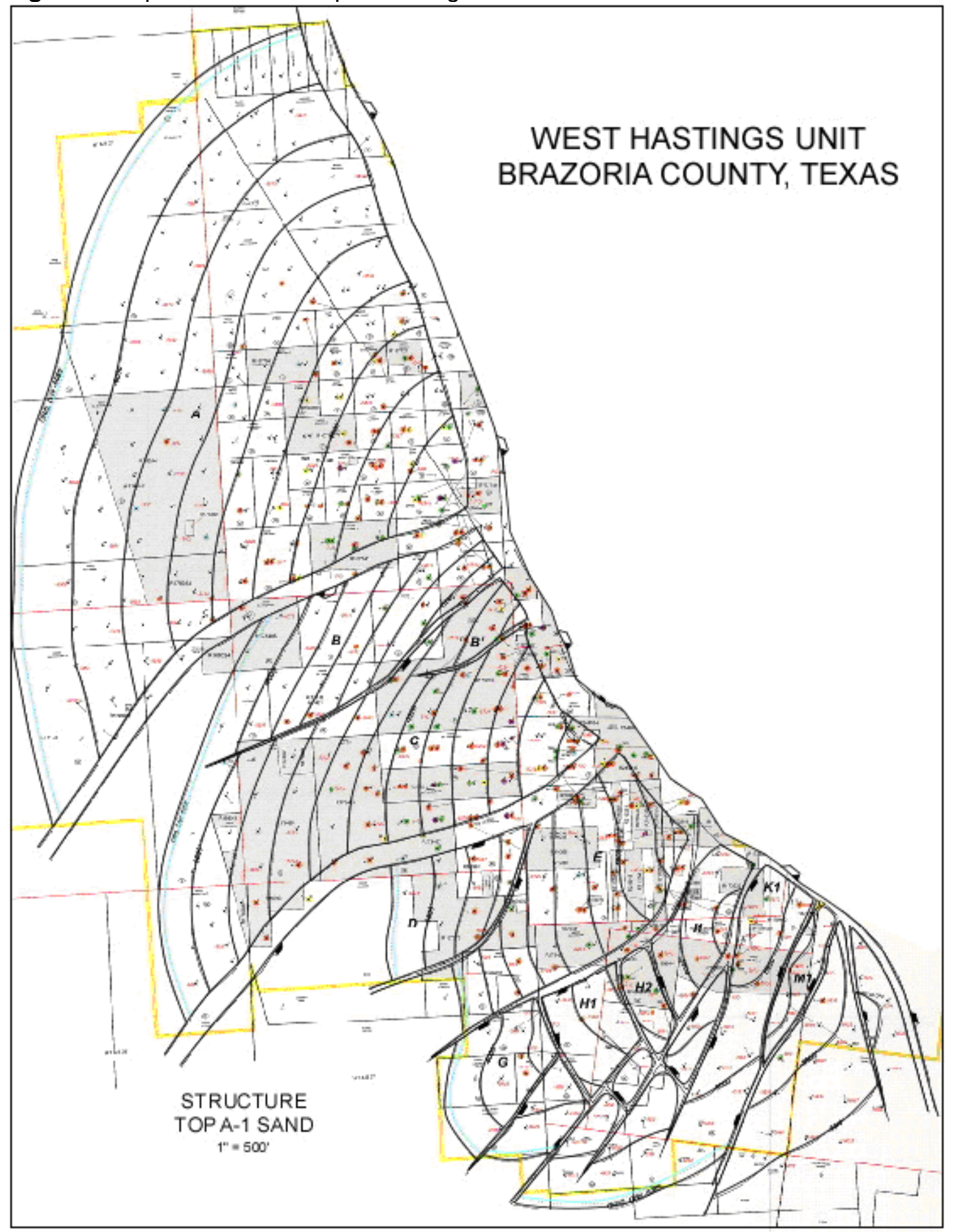

The injectivity of $\mathrm{CO}_{2}$ can be estimated from current water injection rates of existing Frio injectors. Water injection into the Frio of $\sim 180,000$ BWPD is being accomplished with 20 wells, an average of 9000 BWPD per well. Based on a $\mathrm{CO}_{2}$ formation volume factor of $2 \mathrm{MCF} / \mathrm{bbl}$, this would equate to 18 MMCFD ( $\sim 947$ metric tons per day or 0.345 million metric tons/year) $\mathrm{CO}_{2}$ 
per well. This rate is also consistent with the maximum erosional velocity limit of $\mathrm{CO}_{2}$ down 27/8" tubing, thus establishing a target injection per injector. Insuring high injection rates into each pattern maximizes the rate at which oil is recovered, therefore improving project economics.

Table 1. Field Storage Capacity (Fault Blocks B \& C)

\begin{tabular}{|c|c|c|c|c|c|c|c|c|c|}
\hline \multirow[t]{7}{*}{ Upper Frio } & Sand & $\begin{array}{c}\text { Area } \\
\text { (acres) }\end{array}$ & $\begin{array}{c}\text { Thickness } \\
\text { (feet) }\end{array}$ & $\begin{array}{l}\text { Net-to-Gross } \\
\text { (decimal) }\end{array}$ & $\begin{array}{l}\text { Porosity } \\
\text { (decimal) }\end{array}$ & $\begin{array}{c}\text { Swi } \\
\text { (decimal) }\end{array}$ & $\begin{array}{c}\text { Boi } \\
\text { (RB/STB) }\end{array}$ & $\begin{array}{l}\text { OOIP } \\
\text { (bbls) }\end{array}$ & $\begin{array}{l}\text { CO2 Capacity } \\
\text { (MMCF) }\end{array}$ \\
\hline & A1 & 700 & 20 & 0.61 & 0.3 & 0.8 & 1.2 & $13,350,940$ & 32,042 \\
\hline & $\mathrm{A} 2$ & 675 & 30 & 0.61 & 0.3 & 0.8 & 1.2 & $19,311,181$ & 46,347 \\
\hline & A3 & 650 & 50 & 0.61 & 0.3 & 0.8 & 1.2 & $30,993,253$ & 74,384 \\
\hline & A4 & 625 & 40 & 0.61 & 0.3 & 0.8 & 1.2 & $23,840,964$ & 57,218 \\
\hline & A5 & 600 & 20 & 0.61 & 0.3 & 0.8 & 1.2 & $11,443,663$ & 27,465 \\
\hline & A - Total & & 160 & & & & & $98,940,000$ & 237,456 \\
\hline \multirow[t]{34}{*}{ Lower Frio } & Sand & $\begin{array}{l}\text { Acres } \\
\text { (acres) }\end{array}$ & $\begin{array}{l}\text { Thickness } \\
\text { (feet) }\end{array}$ & $\begin{array}{l}\text { Net-to-Gross } \\
\text { (decimal) }\end{array}$ & $\begin{array}{l}\text { Porosity } \\
\text { (decimal) }\end{array}$ & $\begin{array}{c}\text { Swi } \\
\text { (decimal) }\end{array}$ & $\begin{array}{c}\text { Boi } \\
\text { (RB/STB) }\end{array}$ & $\begin{array}{l}\text { OOIP } \\
\text { (bbls) }\end{array}$ & $\begin{array}{l}\text { CO2 Capacity } \\
\text { (MMCF) }\end{array}$ \\
\hline & B1 & 360 & 5 & 0.59 & 0.3 & 0.8 & 1.2 & $1,642,128$ & 3,941 \\
\hline & B2 & 360 & 30 & 0.59 & 0.3 & 0.8 & 1.2 & $9,852,768$ & 23,647 \\
\hline & B3 & 360 & 5 & 0.59 & 0.3 & 0.8 & 1.2 & $1,642,128$ & 3,941 \\
\hline & B - Total & & & & & & & $13,137,024$ & 31,529 \\
\hline & $\mathrm{C} 1$ & 300 & 5 & 0.87 & 0.3 & 0.8 & 1.2 & $2,016,919$ & 4,841 \\
\hline & $\mathrm{C} 2$ & 300 & 20 & 0.87 & 0.3 & 0.8 & 1.2 & $8,067,675$ & 19,362 \\
\hline & C3 & 300 & 20 & 0.87 & 0.3 & 0.8 & 1.2 & $8,067,675$ & 19,362 \\
\hline & C - Total & & & & & & & $18,152,269$ & 43,565 \\
\hline & $\mathrm{D} 1$ & 250 & 20 & 0.87 & 0.3 & 0.8 & 1.2 & $6,723,063$ & 16,135 \\
\hline & D2 & 250 & 20 & 0.87 & 0.3 & 0.8 & 1.2 & $6,723,063$ & 16,135 \\
\hline & D3 & 250 & 20 & 0.87 & 0.3 & 0.8 & 1.2 & $6,723,063$ & 16,135 \\
\hline & D4 & 250 & 20 & 0.87 & 0.3 & 0.8 & 1.2 & $6,723,063$ & 16,135 \\
\hline & D - Total & & & & & & & $26,892,251$ & 64,541 \\
\hline & E1 & 200 & 25 & 1.00 & 0.3 & 0.8 & 1.2 & $7,758,000$ & 18,619 \\
\hline & E2 & 200 & 25 & 1.00 & 0.3 & 0.8 & 1.2 & $7,758,000$ & 18,619 \\
\hline & E - Total & & & & & & & $15,516,000$ & 37,238 \\
\hline & $\mathrm{F} 1$ & 175 & 30 & 1.00 & 0.3 & 0.8 & 1.2 & $8,145,900$ & 19,550 \\
\hline & $\mathrm{F} 2$ & 175 & 35 & 1.00 & 0.3 & 0.8 & 1.2 & $9,503,550$ & 22,809 \\
\hline & F3 & 175 & 30 & 1.00 & 0.3 & 0.8 & 1.2 & $8,145,900$ & 19,550 \\
\hline & F4 & 175 & 11 & 1.00 & 0.3 & 0.8 & 1.2 & $3,095,442$ & 7,429 \\
\hline & F - Total & & & & & & & $28,890,792$ & 69,338 \\
\hline & G1 & 150 & 30 & 0.92 & 0.3 & 0.8 & 1.2 & $6,389,545$ & 15,335 \\
\hline & $\mathrm{G} 2$ & 150 & 20 & 0.92 & 0.3 & 0.8 & 1.2 & $4,259,696$ & 10,223 \\
\hline & G3 & 150 & 30 & 0.92 & 0.3 & 0.8 & 1.2 & $6,389,545$ & 15,335 \\
\hline & G4 & 150 & 10 & 0.92 & 0.3 & 0.8 & 1.2 & $2,129,848$ & 5,112 \\
\hline & G - Total & & & & & & & $19,168,634$ & 46,005 \\
\hline & $\mathrm{H} 1$ & 92 & 40 & 0.93 & 0.3 & 0.8 & 1.2 & $5,283,563$ & 12,681 \\
\hline & $\mathrm{H} 2$ & 92 & 15 & 0.93 & 0.3 & 0.8 & 1.2 & $1,981,336$ & 4,755 \\
\hline & $\mathrm{H} 3$ & 92 & 15 & 0.93 & 0.3 & 0.8 & 1.2 & $1,981,336$ & 4,755 \\
\hline & $\mathrm{H} 4$ & 92 & 50 & 0.93 & 0.3 & 0.8 & 1.2 & $6,604,454$ & 15,851 \\
\hline & H - Total & & & & & & & $15,850,689$ & 38,042 \\
\hline & Total & & & & & & & $137,607,659$ & 330,258 \\
\hline & Grand 1 & otal & & & & & & $236,547,659$ & 567,714 \\
\hline
\end{tabular}

\section{Storage Capacity}

The storage capacity for reservoirs to be flooded in fault blocks $B$ and $C$ is shown in Table 1 . A simple estimate can be made by assuming the volume of original oil-in-place can be replaced on a volume per volume basis by $\mathrm{CO}_{2}$, as done in the NATCARB atlas. The 237 million barrels oil produced occupied 284 million reservoir barrels (1.2 RB/STB) and based upon $2 \mathrm{MCF} \mathrm{CO}_{2}$ 
per reservoir barrel at 160 degrees $\mathrm{F}$ and $3000 \mathrm{psi}$, the $\mathrm{CO}_{2}$ volume to completely displace the original hydrocarbon pore volume will be 568 BCF (31 million metric tons). Areal and vertical sweep efficiency will reduce this number, as will the residual oil saturation to $\mathrm{CO}_{2}$ injection.

Figure 5. Type Log for West Hastings Fault Block B \& C

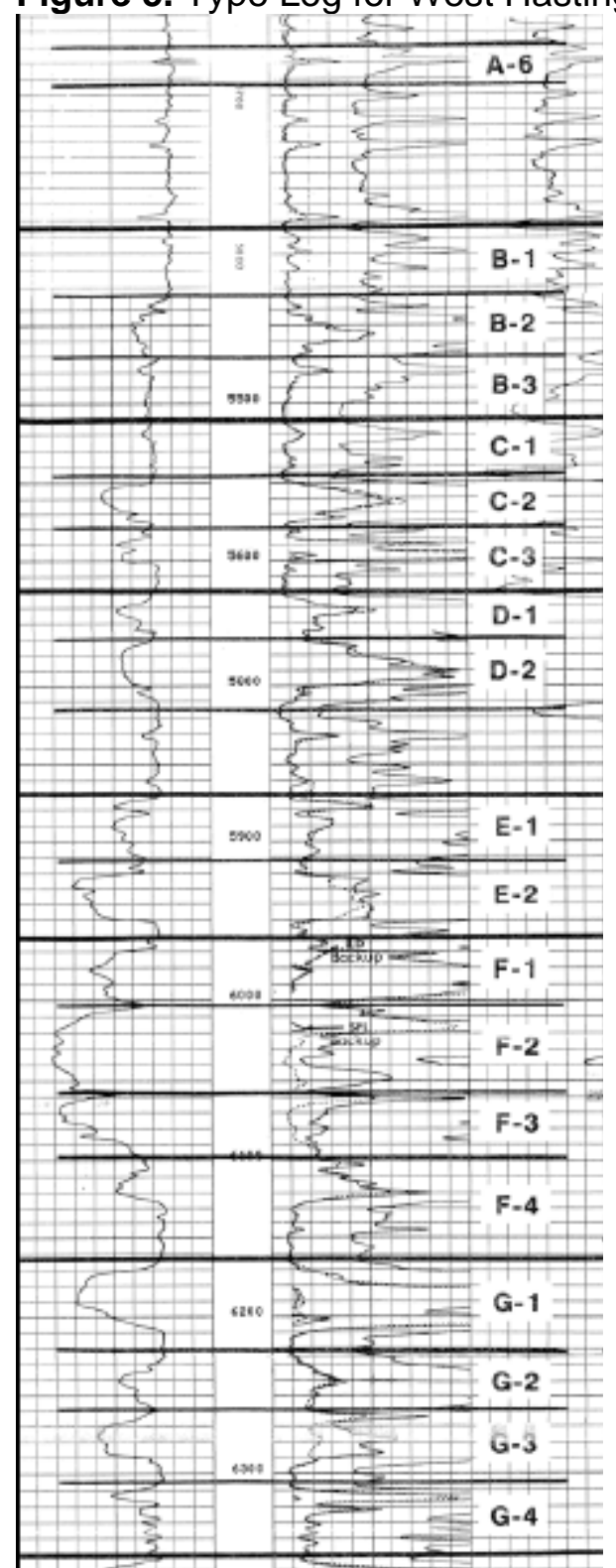

The West Hastings Development team recently cored a well in fault block A (WHU-3706) to determine reservoir properties for the ten major sands of the upper and lower Frio reservoirs (figure 5). Plugs have been cut from the core and measurements of permeability are reported in Table 2. Additional tests will also be performed to determine connate water and residual oil saturation endpoints on approximately 5 plugs, along with oil/water and gas/oil relative permeability curves. This information will be used to guide in the selection of perforated intervals and to better understand the vertical sweep efficiency expected during the $\mathrm{CO}_{2}$ flooding process. Good water drive during production indicates that pressure increase during injection will not limit injection rates, in contrast it is expected that water injection prior to and 
down-dip of $\mathrm{CO}_{2}$ injection will be required to augment $\mathrm{CO}_{2}$ so that injection pressure can be raised from 2200 psi to 3100 psi desired for EOR.

Table 2. Results of core-based permeability form fault block $A$.

\begin{tabular}{|l|c|l|c|}
\hline Sand & $\begin{array}{c}\text { Horizontal } \\
\text { Permeability } \\
\text { (md) }\end{array}$ & Sand & $\begin{array}{c}\text { Horizontal } \\
\text { Permeability } \\
\text { (md) }\end{array}$ \\
\hline A1 & 238 & D1 & 812 \\
\hline A2 & 199 & D2 & 718 \\
\hline A3 & 1282 & E1 & 60 \\
\hline A4 & 950 & E2 & 665 \\
\hline A4-L & 1363 & F1 & 1160 \\
\hline A5 & 1240 & F2 & 272 \\
\hline A6 & 7 & F3 & 317 \\
\hline B1 & 513 & F4 & 8 \\
\hline C2 & 515 & G1 & 162 \\
\hline C3 & 304 & G2 & 108 \\
\hline & & G3 & 117 \\
\hline & & G4 & 244 \\
\hline
\end{tabular}

In general, the Frio sands of West Hastings Field are typical of most sandstones along the Texas and Louisiana Gulf Coast, where porosities are in the $28-32 \%$ range and permeabilities are high, in the $200-2000$ md range. With initial oil saturation of approximately $80 \%$, this suggests high storage capacity for the reservoir rock. The West Hastings Frio reservoir is an excellent reservoir for $\mathrm{CO}_{2}$-EOR recovery as well as $\mathrm{CO}_{2}$ storage. High primary (water drive) recoveries indicate that the areal and vertical sweep efficiencies should be excellent.

\section{Pattern Selection - Upper Frio}

The pattern design selected for Fault Blocks $B$ \& $C$ is different than the one used for Fault Block $A$, as the existing well configuration in $B \& C$ indicated that smaller patterns ( 40 acres each) with larger completion intervals ( 100-150 feet) would make most efficient use of existing wellbores, limiting the number of new wells which would have to be drilled. Fault Block $A$, on the other hand, is planning to use larger patterns ( 140 acres) with smaller completion intervals ( $\sim 50-75$ feet). The Fault Block A pattern required that one set of patterns be used for the A1 \& A2 sand, and another set for the A3, A4, and A5 sands. If this approach was utilized in Fault Blocks $B$ \& $C$, it is likely that over 20 wells would have to be drilled to accommodate the multiple pattern scenario. The current design requires that less than 5 wells be drilled.

Figure 6 is the pattern design for the Upper Frio. In addition to the $14 \mathrm{CO}_{2}$ injectors and 61 producers, downdip water injection will be required to create a high pressure barrier between the residual oil zone and the large aquifer downdip. Commercial reservoir modeling indicates that the high permeability sands will not pressure up easily due to leakoff of the $\mathrm{CO}_{2}$ (or water) into the aquifer. By utilizing the 4 most downdip $\mathrm{CO}_{2}$ injection wells as water injectors initially, pressure can be raised from 2200 psi to 3100 psi in the updip patterns when $\mathrm{CO}_{2}$ injection begins. As a result, expenditures on water injection is required during 2013 prior to $\mathrm{CO}_{2}$ injection. 
Figure 6. Upper Frio - Fault Blocks B \& C Development

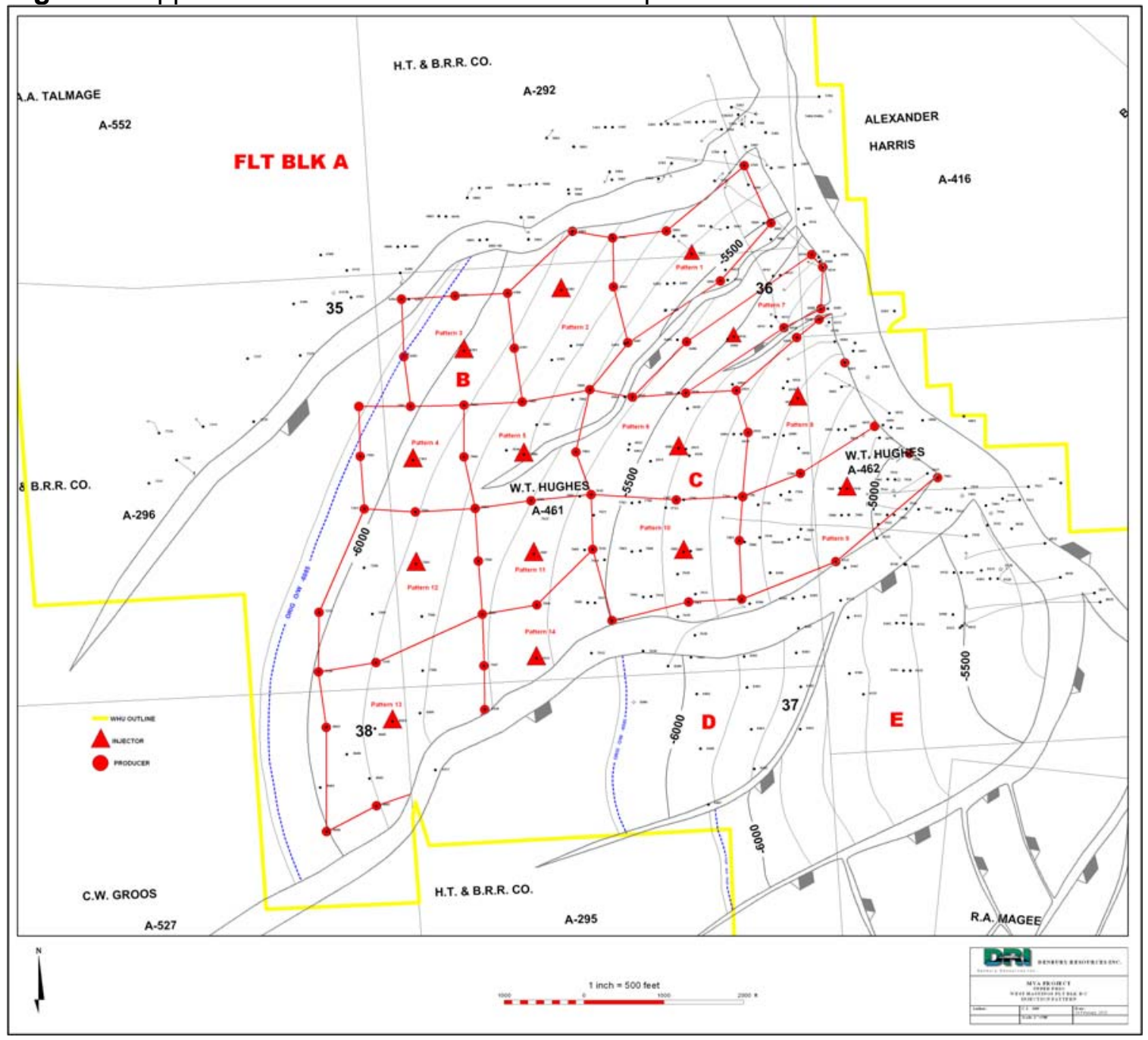

\section{Pattern Selection - Lower Frio}

Unlike Fault Block A which only required two patterns in the Lower Frio to develop a majority of the reserves, Fault Block $\mathrm{C}$ requires a minimum of 5 patterns to recovery the $\mathrm{CO}_{2}$ target oil. As was shown in Table 1, the Lower Frio contained 138 million barrels original oil-in-place versus 99 million barrels in the Upper Frio, a 39\% increase. Since the patterns are relatively small due to the oil-water contact being close in to the major growth fault, downdip $\mathrm{CO}_{2}$ injection is shown as the preferred design (figure 7). The plan currently calls for patterns in the (1) B/C, (2) D, (3) $\mathrm{E}$, (4) $\mathrm{F} / \mathrm{G}$, and (5) $\mathrm{H}$, with $3 \mathrm{CO}_{2}$ injectors downdip for each pattern. In addition to the $15 \mathrm{CO}_{2}$ injectors and 18 producers shown for development, downdip water injection will also be required for the Lower Frio development. Strategically placed wells downdip of the B sand original oilwater contact should allow for all of the Lower Frio sands to be pressured up. 
Figure 7. Lower Frio - Fault Blocks B \& C Development

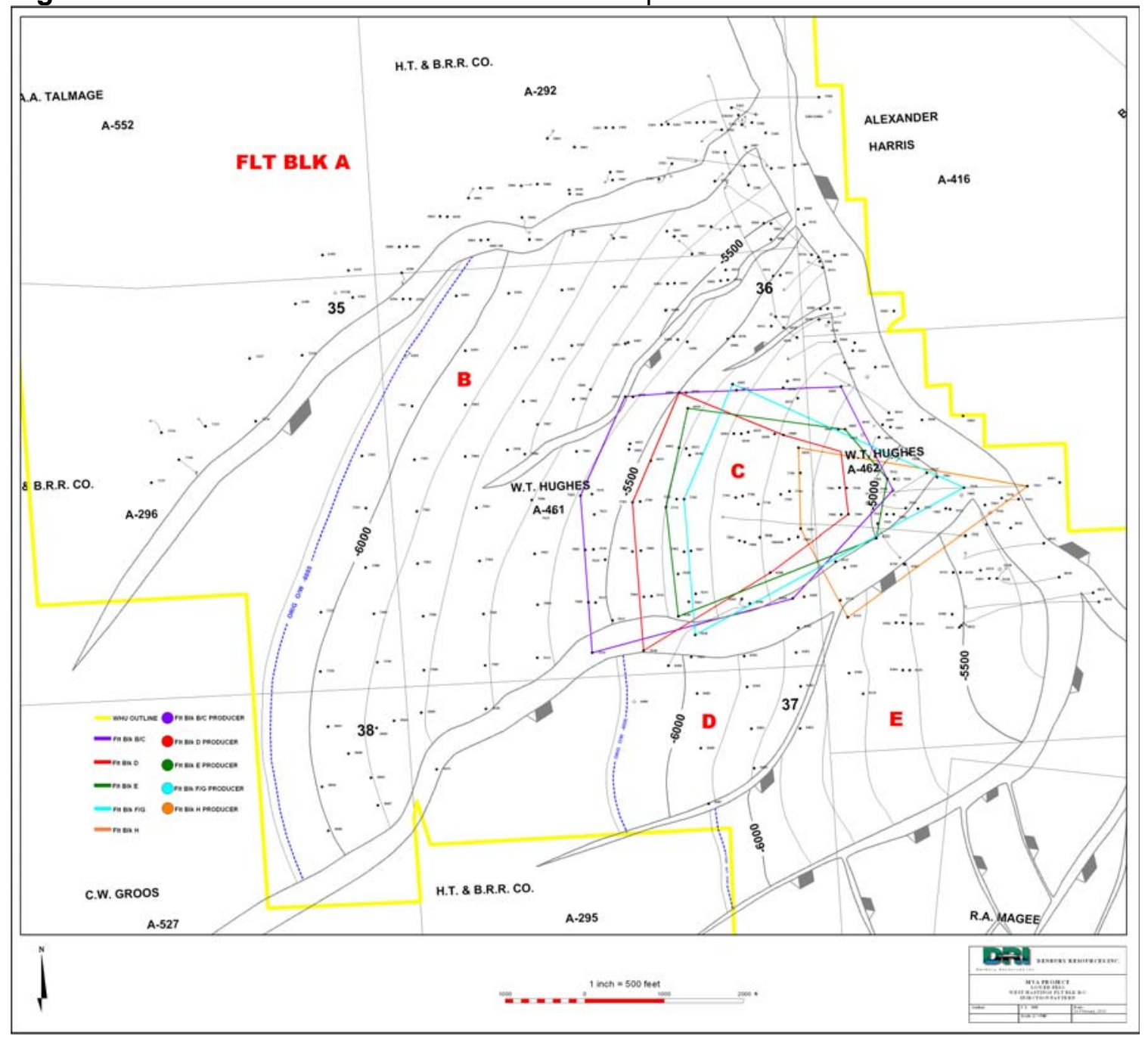

Production Forecast

Since a geologic model and compositional reservoir simulation model is not available for Fault Blocks $\mathrm{B} \& \mathrm{C}, \mathrm{CO}_{2}$ purchase and recycle volumes were forecasted using dimensionless curves obtained from an analogous field and verified by modeling work performed for Fault Block $A$. We therefore have confidence that they can be applied to Fault Blocks B \& C.

The dimensionless curves are used by converting the cumulative $\mathrm{CO}_{2}$ injected into a percent $\mathrm{HCPV}$ (hydrocarbon pore volume) injected and reading off the oil recovery (\% OOIP) and $\mathrm{CO}_{2}$ produced (\% HCPV) values (figure 8 ). This provides the amount of oil which is produced with each increment, and also determines the incremental produced gas (CO2) volume. Spreadsheets are used to convert acres and reservoir thickness into HCPV percentages. A summary of the assumptions for Fault Blocks B \& $C$ are shown in Table 3. 
Figure 8. EOR Dimensionless Curves.

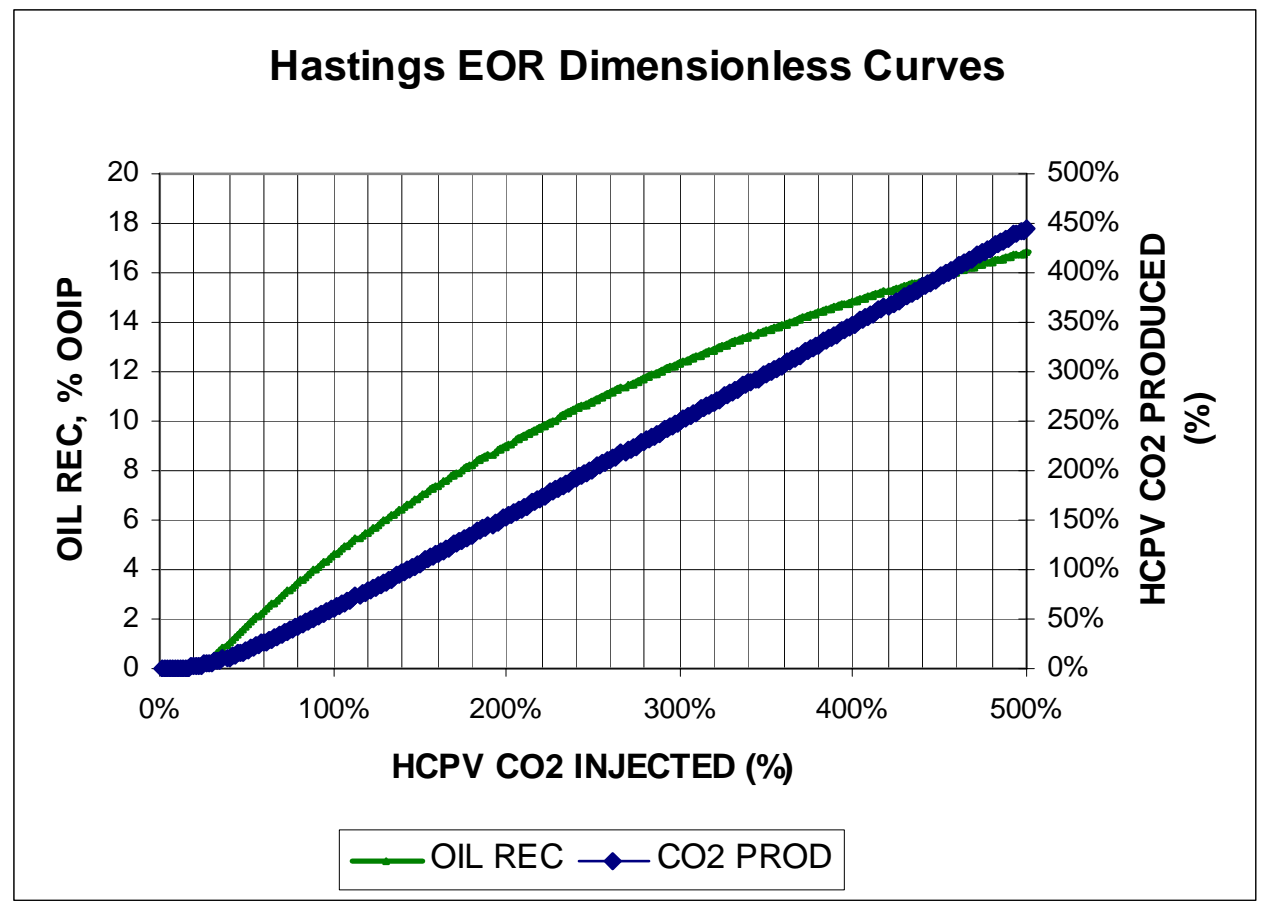

Table 3. CO2 Flood Pattern Size (Fault Blocks B \& C)

\begin{tabular}{|c|c|c|c|c|c|c|c|c|c|c|c|c|}
\hline Pattern & Sands & Pattern & $\mathrm{FB}$ & \begin{tabular}{|l|} 
Thickness \\
\end{tabular} & Acreage & Start Date & CO2 Inj & Swi & Porosity & Boi & OOIP (MBO) & Inj/Yr (\% HCPV/yr) \\
\hline 1 & Upper & 9 & B \& C & 100 & 63 & 7/1/2013 & 18,000 & $20 \%$ & $30 \%$ & 1.2 & 9,719 & \\
\hline 2 & Upper & 8 & $B \& C$ & 100 & 51 & 9/1/2013 & 18,000 & $20 \%$ & $30 \%$ & 1.2 & 7,926 & $34.5 \%$ \\
\hline 3 & Lower & $\mathrm{H}$ & B \& C & 120 & 74 & 9/1/2013 & 18,000 & $20 \%$ & $30 \%$ & 1.2 & 13,778 & 19.9 \\
\hline 4 & Upper & 6 & B \& C & 100 & 61 & $11 / 1 / 2013$ & 18,000 & $20 \%$ & $30 \%$ & 1.2 & 9,407 & $29.1 \%$ \\
\hline 5 & Lower & F/G & $B \& C$ & 175 & 127 & $11 / 1 / 2013$ & 54,000 & $20 \%$ & $30 \%$ & 1.2 & 34,484 & $23.8 \%$ \\
\hline 6 & Upper & 10 & $B \& C$ & 100 & 57 & 7/1/2014 & 18,000 & $20 \%$ & $30 \%$ & 1.2 & 8,852 & 30.9 \\
\hline 7 & Lower & $E$ & $B \& C$ & 50 & 115 & 7/1/2014 & 18,000 & $20 \%$ & $30 \%$ & 1.2 & 8,922 & $30.7 \%$ \\
\hline 8 & Upper & 7 & $B \& C$ & 100 & 31 & 9/1/2014 & 18,000 & $20 \%$ & $30 \%$ & 1.2 & 4,770 & $57.4 \%$ \\
\hline 9 & Lower & $\mathrm{D}$ & $B \& C$ & 80 & 120 & 9/1/2014 & 18,000 & $20 \%$ & $30 \%$ & 1.2 & 14,895 & 18.4 \\
\hline 10 & Upper & 11 & B \& C & 100 & 38 & $11 / 1 / 2014$ & 18,000 & $20 \%$ & $30 \%$ & 1.2 & 5,933 & $46.1 \%$ \\
\hline 11 & Lower & $\mathrm{B} / \mathrm{C}$ & $B \& C$ & 85 & 216 & $11 / 1 / 2014$ & 36,000 & $20 \%$ & $30 \%$ & 1.2 & 28,487 & $19.2 \%$ \\
\hline 12 & Upper & 14 & $B \& C$ & 100 & 35 & 7/1/2015 & 18,000 & $20 \%$ & $30 \%$ & 1.2 & 5,468 & $\overline{50.1}$ \\
\hline 13 & Upper & 1 & $B \& C$ & 100 & 47 & $8 / 1 / 2015$ & 18,000 & $20 \%$ & $30 \%$ & 1.2 & 7,336 & $37.3 \%$ \\
\hline 14 & Upper & 2 & $B \& C$ & 100 & 53 & 9/1/2015 & 18,000 & $20 \%$ & $30 \%$ & 1.2 & 8,206 & $33.4 \%$ \\
\hline 15 & Upper & 3 & $B \& C$ & 100 & 43 & 10/1/2015 & 18,000 & $20 \%$ & $30 \%$ & 1.2 & 6,714 & 40.8 \\
\hline 16 & Upper & 4 & $B \& C$ & 100 & 40 & 10/1/2015 & 18,000 & $20 \%$ & $30 \%$ & 1.2 & 6,180 & $44.3 \%$ \\
\hline 17 & Upper & 5 & $B$ \& C & 100 & 43 & $11 / 1 / 2015$ & 18,000 & $20 \%$ & $30 \%$ & 1.2 & 6,641 & 41.2 \\
\hline 18 & Upper & 12 & $B \& C$ & 100 & 72 & $11 / 1 / 2015$ & 18,000 & $20 \%$ & $30 \%$ & 1.2 & 11,158 & 24.5 \\
\hline 19 & Upper & 13 & $B \& C$ & 100 & 75 & $12 / 1 / 2015$ & 18,000 & $20 \%$ & $30 \%$ & 1.2 & 11,592 & $23.6 \%$ \\
\hline & & & & & & & & & & & & \\
\hline TOTAL & & & & & & & 396,000 & & & & 210,468 & \\
\hline
\end{tabular}

Since the F/G sand combination is so thick, a portion of it will likely be combined with the $E$ and/or $\mathrm{H}$ sands to allow for more uniform distribution. Another option is that the $\mathrm{F} \& \mathrm{G}$ sands may be flooded separately. Given that each of the Lower Frio sands have 3 injectors, a maximum of 54 MMCFD is achievable, so the 36 MMCFD shown for B/C and 54 MMCFD for F/G does not exceed the design limits.

The table shows that 210 million barrels OOIP (89\%) will be $\mathrm{CO}_{2}$ flooded out of the total 237 million. The additional $11 \%$ of the volume is on the edges near the original oil water contact and in areas of the Lower Frio where the current configuration does not sweep. As we get closer to executing the project, slight adjustments may be made to maximize sweep. 
Using this information, the $\mathrm{CO} 2$ purchase, recycle (produced), and injection volumes are shown in Figure 9. The 396 MMCFD CO2 injection is shown, with peak CO2 purchase of 211 MMCFD occurring during December, 2015.

Figure 9. Projected $\mathrm{CO}_{2}$ Volumes

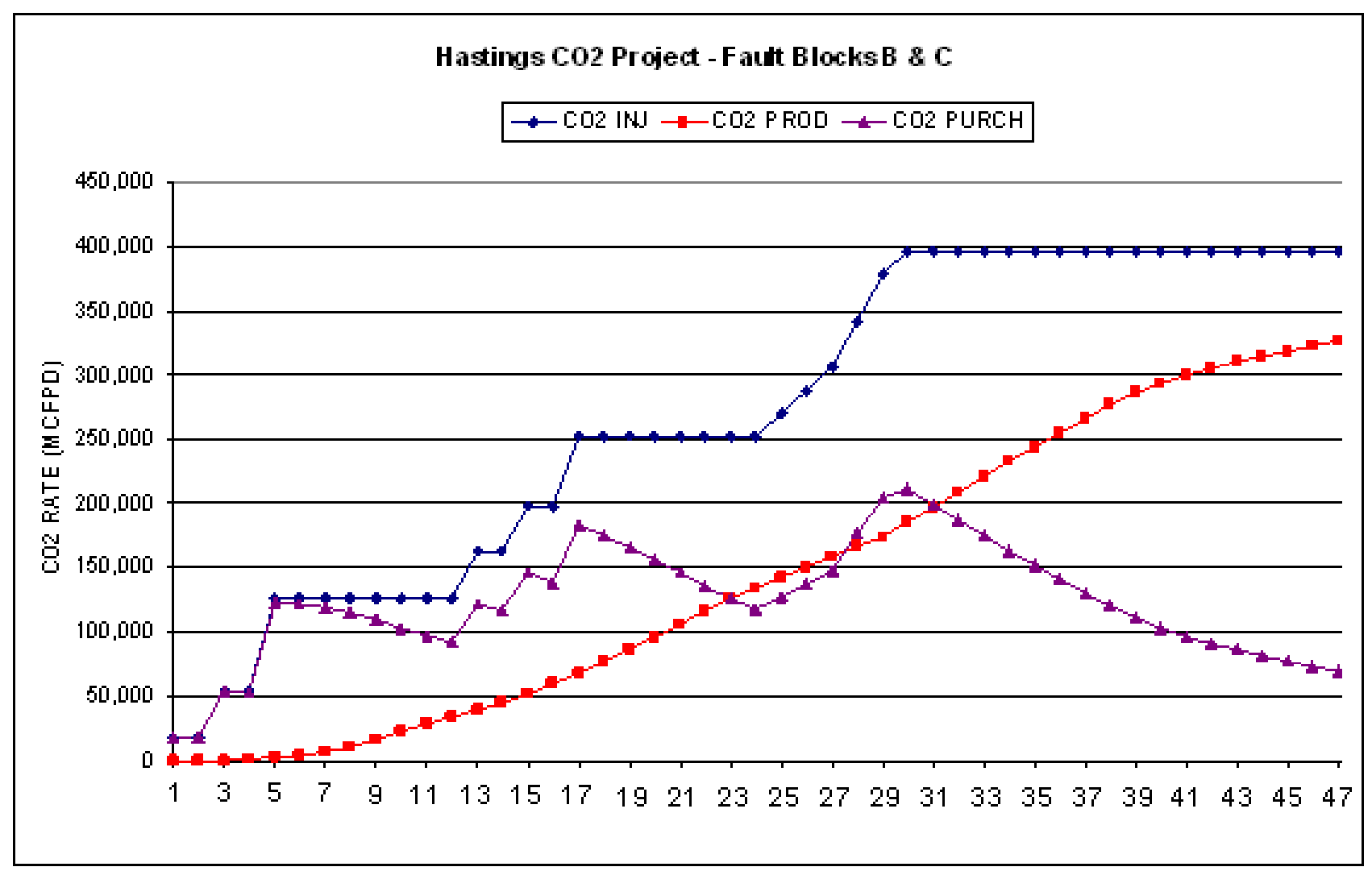

Table 4 is a month by month estimate of $\mathrm{CO}_{2}$ purchase volumes, including the estimate of number of $\mathrm{CO}_{2}$ injectors and patterns developed in Fault Blocks B \& $\mathrm{C}$. These estimates are impacted by capital expenditure levels available for prior years, yet is felt to be a reasonable forecast. If the anthropogenic $\mathrm{CO}_{2}$ is not ready by January, 2014, $\mathrm{CO}_{2}$ from Denbury's Jackson Dome may be utilized.

The table indicates that peak purchases will be around 200 MMCFPD by month 30 . A total of 145 BCF (or 8.4 million tons) will be injected over the first 3 year period. 
Table 4. Anticipated Hastings Fault Block B \& C Development Schedule

\begin{tabular}{|c|c|c|c|c|c|c|c|}
\hline Month & $\begin{array}{c}\mathrm{COZ} \\
\text { Purch sised } \\
\text { Volumes } \\
\text { (mucF) }\end{array}$ & $\begin{array}{c}\mathrm{COZ} \\
\text { Purdised } \\
\text { Volumes } \\
\text { (MMCF id) }\end{array}$ & $\begin{array}{l}\text { Cumulative } \\
\text { co2 } \\
\text { Purchased } \\
\text { Volumes } \\
\text { (HucF) }\end{array}$ & $\begin{array}{l}\text { Cumulative } \\
\# \text { injectors }\end{array}$ & $\begin{array}{c}\text { Cumulative \# } \\
\text { patterns }\end{array}$ & $\begin{array}{c}\text { Cumulative \# } \\
\text { Upper F rio } \\
\text { Pattems }\end{array}$ & $\begin{array}{c}\text { Cumulative \# } \\
\text { Lower Frio } \\
\text { Patterns }\end{array}$ \\
\hline Jan-14 & 547 & 18 & 547 & 1 & 1 & 1 & 0 \\
\hline Feb-14 & 547 & 18 & 1,094 & 1 & 1 & 1 & 0 \\
\hline Mar-14 & 1,642 & 54 & 2,736 & 5 & 3 & 2 & 1 \\
\hline Apr-14 & 1.613 & 53 & 4,349 & 5 & 3 & 2 & 1 \\
\hline May-14 & 3,760 & 124 & 8,109 & 9 & 5 & 3 & 2 \\
\hline Jun-14 & 3.699 & 122 & 11,808 & g & 5 & 3 & 2 \\
\hline Jul-14 & 3,624 & 119 & 15,431 & 9 & 5 & 3 & 2 \\
\hline Auq-14 & 3.495 & 115 & 18.927 & g & 5 & 3 & 2 \\
\hline Sep-14 & 3,320 & 109 & 22,247 & 9 & 5 & 3 & 2 \\
\hline Oct-14 & 3,135 & 103 & 25,382 & 9 & 5 & 3 & 2 \\
\hline Nov-14 & 2,955 & 97 & 28,337 & 9 & 5 & 3 & 2 \\
\hline Dec-14 & 2,787 & 92 & 31,124 & 9 & 5 & 3 & 2 \\
\hline Jan-15 & 3.729 & 123 & 34,852 & 13 & 7 & 4 & 3 \\
\hline Feb-15 & 3,562 & 117 & 38,414 & 13 & 7 & 4 & 3 \\
\hline Mar-15 & 4,470 & 147 & 42,884 & 17 & 9 & 5 & 4 \\
\hline Apr-15 & 4,196 & 138 & 47,080 & 17 & 9 & 5 & 4 \\
\hline May-15 & 5,582 & 184 & 52,663 & 21 & 11 & 6 & 5 \\
\hline Jun-15 & 5,331 & 175 & 57,994 & 21 & 11 & 6 & 5 \\
\hline Jul-15 & 5,042 & 166 & 63,036 & 21 & 11 & 6 & 5 \\
\hline Aug-15 & 4,754 & 156 & 67,790 & 21 & 11 & 6 & 5 \\
\hline Sep-15 & 4,454 & 147 & 72,244 & 21 & 11 & 6 & 5 \\
\hline Oct-15 & 4,109 & 135 & 76,354 & 21 & 11 & 6 & 5 \\
\hline Nov-15 & 3,822 & 126 & 80,175 & 21 & 11 & 6 & 5 \\
\hline Dec-15 & 3,569 & 117 & 83,745 & 21 & 11 & 6 & 5 \\
\hline Jan-16 & 3,876 & 128 & 87,621 & 22 & 12 & 7 & 5 \\
\hline Feb-16 & 4,176 & 137 & 91,797 & 23 & 13 & 8 & 5 \\
\hline Mar-16 & 4,489 & 148 & 96,286 & 24 & 14 & 9 & 5 \\
\hline Apr-16 & 5,344 & 176 & 101,629 & 26 & 16 & 11 & 5 \\
\hline May-16 & 6.205 & 204 & 107,834 & 28 & 18 & 13 & 5 \\
\hline Jun-16 & 6,409 & 211 & 114,244 & 29 & 19 & 14 & 5 \\
\hline Jul-16 & 6,049 & 199 & 120,292 & 29 & 19 & 14 & 5 \\
\hline Aug-16 & 5,702 & 188 & 125,994 & 29 & 19 & 14 & 5 \\
\hline Sep-16 & 5,331 & 175 & 131,325 & 29 & 19 & 14 & 5 \\
\hline Oct-16 & 4,961 & 163 & 136,286 & 29 & 19 & 14 & 5 \\
\hline Nov-16 & 4,619 & 152 & 140,906 & 29 & 19 & 14 & 5 \\
\hline Dec-16 & 4,295 & 141 & 145,200 & 29 & 19 & 14 & 5 \\
\hline
\end{tabular}

\section{Projected Well Classification and Quantity}

$\mathrm{CO}_{2}$ will be injected in the Frio Formation. Currently $29 \mathrm{CO}_{2}$ Class II injection wells are planned for Fault Block B \& C development. The $\mathrm{CO}_{2}$ EOR project will utilize a combination of inverted 9 -spots and downdip injection patterns. This phase of the project will require approximately 200 MMCFD CO2 purchases and peak CO2 injection of 400 MMCFD. Target reservoir pressure is around 3100 psi. A target injection rate of 18 MMCFD per well is planned.

All wells will be permitted as Class II injectors. A typical injection well schematic is shown in Figure 10. 
Figure 10. Typical injection well Schematic

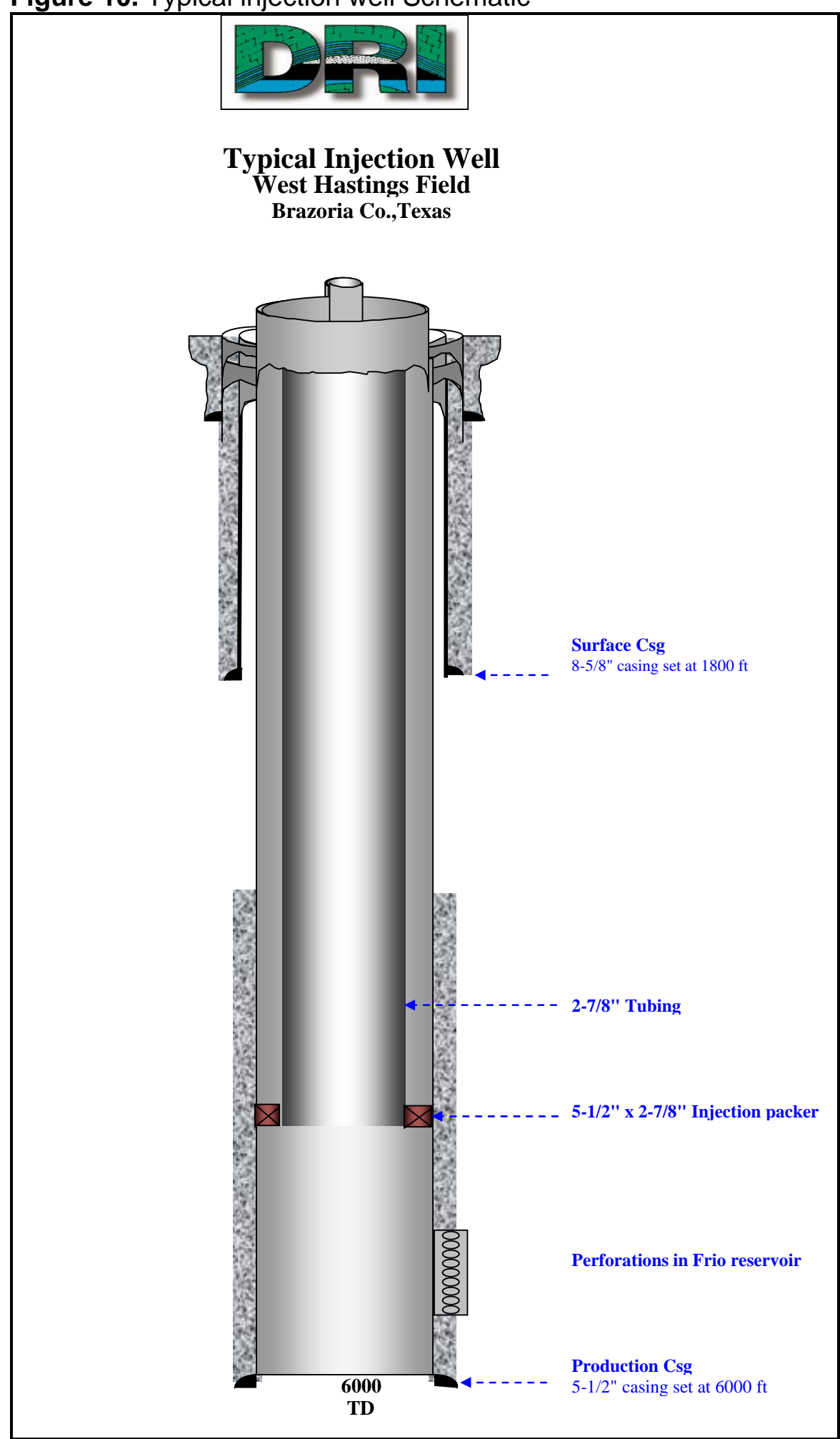




\section{Gulf Coast Carbon Center - Report to Denbury on MVA Planning for FOA 15}

Report Type:

Report number :

Report title:

Completion Date:

Report Issue Date:

Submitting Organization:
Report and documentation of milestone completion C5.2.3.2

C5.2.3.2 Site-specific MVA options evaluation

February 22, 2010

April 11, 2010

Susan D. Hovorka, Principle Investigator, Gulf Coast Carbon Center Bureau of Economic Geology Jackson School of Geosciences The University of Texas at Austin 
Phase I Task C5.2.3.2

Site-specific MVA options evaluation

\author{
Prepared for: \\ Denbury Resources
}

Report by Susan D. Hovorka

\begin{abstract}
April 11, 2010
Bureau of Economic Geology

John A. and Katherine G. Jackson School of Geosciences

The University of Texas at Austin

Austin, Texas 78713-8924
\end{abstract}




\section{Table of Contents}

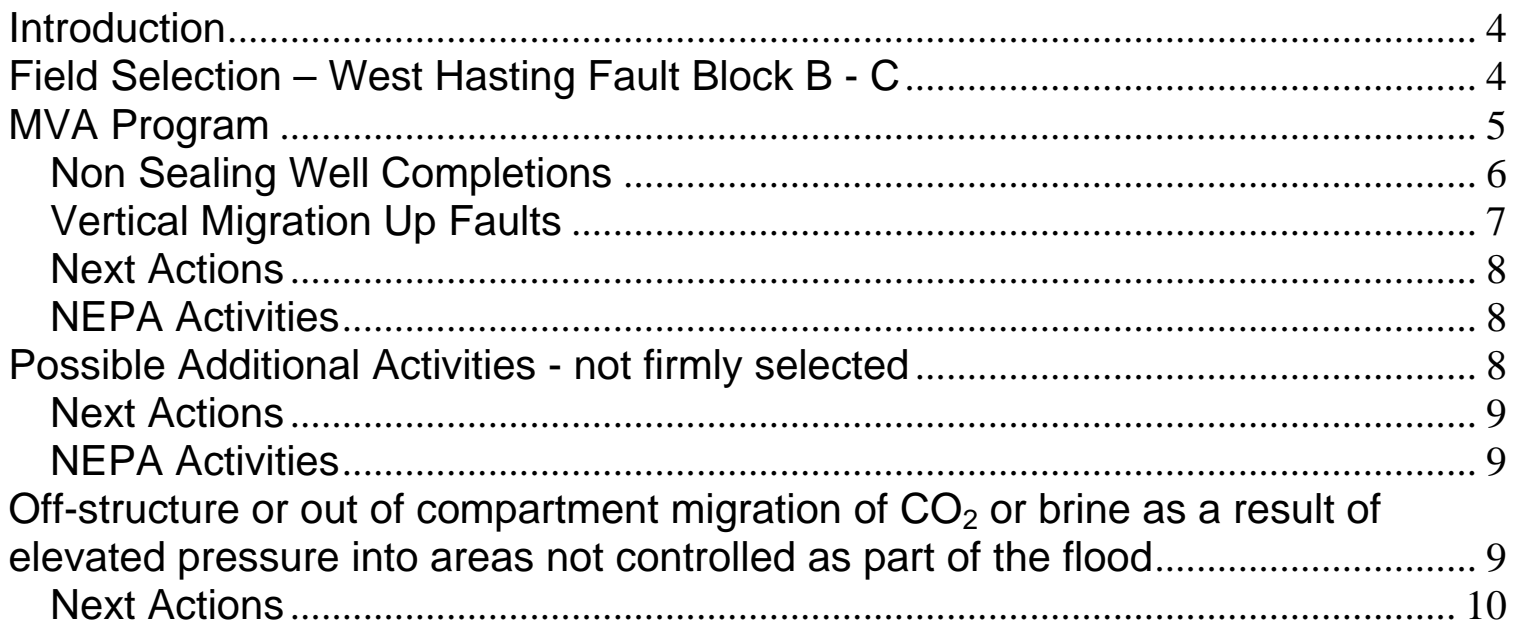

\section{Tables}

Table 1. Commercial MVA program used for reservoir management ...................... 6 


\section{Introduction}

This report documents the planning and progresses for Task C1.5.4.2, evaluation if sitespecific MVA options. On December 15, 2009, a review team composed of Susan Hovorka, University of Texas, Bureau of Economic Geology (BEG) and sixteen Denbury staff refined the plan for development of the Phase I Storage MVA plan for the four capture projects linked to two storage projects proposed under DOE FOA 15. This report recounts the evaluation completed at that meeting, and identifies the field and MVA options selected for further evaluation. This prepares the way for development of detailed proposals that will be judged competitively for major funding in Phase II

The review team completed a formal review of two fields nominated in the initial proposal and selected one that seemed to be most competitive in the context of the next round of proposal preparation: West Hasting fault block B and/or C. We discussed the separation of monitoring activities into (1) those conducted commercially as part of best practices for an effective EOR flood or to meet current regulatory requirements (these are not subject to NEPA) and (2) those geographically and topically limited research-oriented monitoring, verification, and accounting (MVA) activities that will be conducted to further demonstrate the effectiveness of storage. Research MVA will be federally funded and will be subject to NEPA. This report proposes a draft research MVA program. It is intended that this draft discuss a broad scope of all the activities that might be selected for the phase II proposal. This broad scope will help us focus further cost/feasibility/optimization discussion as well as allow preparation of the EIV

\section{Field Selection - West Hasting Fault Block B - C}

Two fields were proposed in the initial proposal from which one was to be selected: Oyster Bayou or Hastings. A list of competitive advantages/possible risks to consider was prepared and jointly reviewed. Issues that were judged to be significant were: temporal and volumetric match between field development and availability of captured $\mathrm{CO}_{2}$ and possible negative implications of the public aspects of using federal funding, in particular the public information associated with NEPA.

The review team felt that a stronger proposal would result if the field expansion (additional patterns) was approximately matched to the captured $\mathrm{CO}_{2}$ (assumed to be 1 million tons per site per year during 2014-15). $\mathrm{CO}_{2}$ is purchased throughout the life of a field even when recycling dominates, however the possible reviewer confusion about "room for $\mathrm{CO}_{2}$ when the field is already full" might weaken a competitive proposal. Also in fields which will be relatively mature and into recycle, the purchase volume needed during the 2014-15 period could not be stated with high confidence in the Phase II proposal. In addition, collecting baseline data prior to completion of the flood will allow the MVA program to be better in line with what the DOE program expects, which will improve its acceptability. The field are in which expansions are planned in 2014 timeframe is Hastings fault block $B$ and $C$ ( $A$ will be becoming mature).

The other factor considered a significant selection parameter is the public comment triggered by NEPA. Public comment related to NEPA will apply only to federally funded 
research MVA activities, as Denbury's commercial field operations will be part of the EOR flood whether or not federal funds are won. Rationally, research MVA activities should provide additional comfort for residents and communities, however where anxiety or hostility are involved, residents may not separate the commercial flood from the research MVA. Local hostility could have possible negative consequences for either commercial or research program. We therefore recommend avoiding locations where the flood may impact a larger population.

The consensus is that a strong proposal can be written for Hastings.

\section{MVA Program}

The MVA program proposed will include two components: a commercial program and an added value research program. The commercial MVA program will be conducted as part of normal best practices, in conformance with state regulations. It is not subject to NEPA review as it will be conducted whether or not federal funding and anthropogenic $\mathrm{CO}_{2}$ is acquired. The research program is designed to test with additional rigor the extent to which a commercial monitoring program is adequate to assure that storage is of quality desired to obtain benefit to the atmosphere. In particular the research program will test for conditions where retention of $\mathrm{CO}_{2}$ is adequate for commercial benefit but may not attain the standards desired for sequestration. The standards desired for sequestration are not codified, however the IPCC target that a well selected site should retain 99\% $\mathrm{CO}_{2}$ in the reservoir over 1000 years meets the DOE's expectations. The research MVA program will be federally funded and subject to NEPA review.

Commercial EOR field monitoring provides assurance that the $\mathrm{CO}_{2}$ flood is performing correctly via reservoir management. In order to create a credible MVA program, Denbury will document that these activities are conducted. In some cases these data are reported to the appropriate state oil and gas regulatory board, however, in other cases data that are now private will need to be documented to demonstrate sequestration. Reservoir management goals and activities are shown in table 1. 
Table 1. Commercial MVA program used for reservoir management

\begin{tabular}{|l|l|l|}
\hline Goal & Methods & $\begin{array}{l}\text { Remedial action if needed } \\
\text { achieve goal }\end{array}$ \\
\hline $\begin{array}{l}\text { Assure no migration } \\
\text { through existing and P\&A } \\
\text { wells for protection of }\end{array}$ & $\begin{array}{l}\text { Examine well completion } \\
\text { records, P\&A records prior } \\
\text { to flood, run cement bond } \\
\text { logs, conduct mechanical } \\
\text { integrity tests, during flood } \\
\text { daily record of casing } \\
\text { pressure at each well (a } \\
\text { truly abandoned well may } \\
\text { not have pressure } \\
\text { recording capablility) }\end{array}$ & $\begin{array}{l}\text { Re-entry and workover to } \\
\text { repair wells if needed, } \\
\text { includes, cement squeezes, } \\
\text { installation of casing liners, } \\
\text { P\&A and redrill if needed. }\end{array}$ \\
\hline $\begin{array}{l}\text { Surveillance of the flood to } \\
\text { assure that injection is } \\
\text { balanced (CO }{ }_{2} \text { is going into } \\
\text { the selected area of the } \\
\text { selected zone and driving } \\
\text { production at selected } \\
\text { producers, pressure is not } \\
\text { above fracture gradient). }\end{array}$ & $\begin{array}{l}\text { Daily record of tubing } \\
\text { pressure on injectors and } \\
\text { producers, minimum } \\
\text { monthly inventory of fluid } \\
\text { volumes produced at each } \\
\text { well at test facility, } \\
\text { intermittent bottom hole } \\
\text { shut-in or flowing well } \\
\text { pressures, intermittent } \\
\text { production/injection logs. }\end{array}$ & $\begin{array}{l}\text { Shut in wells that do not } \\
\text { contribute, } \\
\text { increase/decrease injection } \\
\text { or production rates, modify } \\
\text { perforated interval. } \\
\text { Conformance treatments to } \\
\text { alter injection and/or } \\
\text { production zones. }\end{array}$ \\
\hline $\begin{array}{l}\text { Predict future performance } \\
\text { of reservoir }\end{array}$ & $\begin{array}{l}\text { History match surveillance } \\
\text { data to predictions in } \\
\text { reservoir model. }\end{array}$ & $\begin{array}{l}\text { Correct model as needed to } \\
\text { match history and gain } \\
\text { confidence in future } \\
\text { predictions }\end{array}$ \\
\hline
\end{tabular}

The research MVA program will focus on areas of uncertainty in retention of fluids in the injection zone. As these oil fields have retained oil and gas for geologic time, we consider that it is documented the natural seal is adequate to support a significant $\mathrm{CO}_{2}$ column with migration only at diffusion rates. Risk assessment and experience indicates that the most probable migration paths are (1) non-sealing well completions; (2) vertical migration up fault when reservoir pressure exceeds original pressure (3) off-structure or out of compartment migration of $\mathrm{CO}_{2}$ or brine as a result of elevated pressure into areas not controlled as part of the flood. An MVA program is outlined for each of these risk areas and is linked to a mitigation or management process that will assure that the $\mathrm{CO}_{2}$ injected is permanently stored.

\section{Non Sealing Well Completions}

Wells that penetrate the seal are known to be weak points, especially during injection. Wells that perform adequately during extraction, when they are pressure sinks, can become upwardly transmissive during injection when pressure is increased. Wells that are active can be inspected via a logging program, however wells that have been plugged and abandoned $(P \& A)$ are prohibitively expensive to reenter to inspect. The 
research MVA program will extend the commercial well integrity program, and tests effectiveness of the commercial program.

Activities that will be considered for possible inclusion in the proposal:

(1) Additional logging program (e.g. temperature, radioactive tracers, high end wireline tools)

(2) Above zone pressure monitoring - ambient and introduced fluids

(3) Well deconstruction - possibly associated with workover.

(4) Soil gas, groundwater, or other near-surface monitoring.

In Hastings, water disposal into the Miocene overlying the Frio $\mathrm{CO}_{2}$ injection zone has elevated pressure and perturbed geochemistry. In the short term, this elevated pressure is a barrier to upward flow. It will be interesting to assess how long this pressure barrier will be sustained with respect to long term storage goals. (it should be noted that we are making efforts to restrict or eliminate Miocene water injection as it is creating several adverse problems in the field re-development, will be interesting to monitor how quickly the Miocene "bleeds" off if any with time once injection has been curtailed). It may add difficulties to above-zone detection methods.

Possible methods for looking for flawed wells are:

- Thermal anomalies (hot fluids expelled from depth, or cold areas in shallow zones where $\mathrm{CO}_{2}$ flashes to gas). Can be done though casing

- Noise anomalies - Can be done though casing

- Pressure anomalies - requires perforations

- Geochemical anomalies - requires perforations.

- Soil gas methods near surface (methane, $\mathrm{CO}_{2}$ )

- Augmented soil gas/aquifer surveillance methods (noble gases/isotopes, tracers)

\section{Vertical Migration Up Faults}

Faults related to salt structure are ubiquitous in the Gulf coast. Some faults are clearly vertically transmissive; others trap thick oil and gas columns and are therefore not transmissive at rates relevant to $\mathrm{CO}_{2}$ storage. It is sometimes not clear how faults will perform when pressure is increased, and this uncertainty can be a block to use/storage of anthropogenic $\mathrm{CO}_{2}$ in faulted settings. Technique development is needed to determine effective methods to document that faults are sealed to vertical flow. Soso is mapped as unfaulted at reservoir zone, so this issue does not arise. Hastings has a main growth fault that extends to surface as well as several cross faults. Production history suggest that cross faults maybe somewhat cross-fault transmissive, however the vertical performance has not been assessed.

Activities that will be considered for possible inclusion in the proposal:

(1) Natural fault performance - any near surface soil gas anomalies - methane , noble gasses

(2) Soil gas, groundwater, or other near-surface monitoring, same as above but focused on fault. Location - where master fault approaches surface ( I do not know where this is yet).

(3) Logging program for wells that cut the fault (e.g. temperature, radioactive tracers, high end wireline tools) looking for changes (need before and after injection in wells that cut faults as $\mathrm{CO}_{2}$ is injected). 
(4) Above zone pressure and geochemical monitoring - any changes as $\mathrm{CO}_{2}$ is introduced? may be impossible with water disposal in Miocene. Need to perforate one or more wells where they cut fault. Sample for PFT.

(5) Geophysical methods - design VSP or cross well acoustic array to look for changes along fault plane. Consider passive acoustic methods to determine if their is any viability in ductile rocks in Gulf Coast. Consider gravity methods.

\section{Next Actions}

(1) BEG estimate sensitivity of these methods for reservoirs in question against the $99 \%$ retained over 1000 years standard. Work on concept of proving the container prior to addition of anthropogenic $\mathrm{CO}_{2}$ - using current perturbation to assess for current migration. Feasiblity assessment for which we need basic groundwater, including depth to water and soil data.

(2) Discuss with Denbury field staff what wells could be used for above zone assessment near reservoir depth both during early stages of development and during flood, groundwater wells. Hastings should have a significant number of wells that could be used.

(3) Resolve perspective on the soil gas in these fields.

(4) Develop a detailed "shopping list" request for Sandia to collect needed cost/vendor data

(5) Finalize plan for proposal

(6) Finalize budget for proposal

\section{NEPA Activities}

This review is provided as the bounding conditions to be considered in NEPA review.

\section{Possible Additional Activities - not firmly selected}

Access 1 to 10 existing wells, run various types of wireline wellbore integrity logs (temperature, noise, CBL, USIT, RAT). Select one or more wells not planned for production for plug back/set bridge plug to above-reservoir zone and perforate above zone (presumably in a permeable, "producable" oil, gas or water zone) with a workover rig, produce well with N2 lift to clean formation fluids (several hundred barrels). Completion must allow current geochemical samples and high frequency static fluid pressure. (Surface readout least expensive, downhole certainly possible, but more expensive) Consider simple (pressure transducer to measure fluctuation in static fluid column) and complex, for example Westbay sampler (http://www.slb.com/content/services/additional/water/monitoring/multilevel/westbay mul tilevel well.asp) or Ella G Lees 7 type completions. Record data via data loggers, real time phone system or satellite uplink.

Soil Gas Monitoring - numerous (100?) shallow (20 ft deep) boreholes below active soil zone. Install PVC pipes for soil gas wells, install weather station. Define depth the water, may preclude this approach at Hastings. Location inside lease footprint as defined by active and P\&A wells. Hastings - Add PFT's to injected $\mathrm{CO}_{2}$, detect at surface near producers and in soilgas and groundwater wells. this would require several mobilizations because of uncertainty about transport speed. 
Ground water surveillance - access to about 20 existing or new drill (100-200 ft deep) groundwater wells, cemented in PVC casing with surface protection box. Develop wells so that they can produce groundwater (100 barrels). Location inside footprint plus several up-gradient and several down gradient (off pattern) wells. Noble gas, isotope labs.

We will need to identify labs and do NEPA forms on them also.

\section{Next Actions}

(1) Examine available data on wells that cut faults or could be used for cross-well geometries. Discuss with Denbury availability of well access for monitoring activities.

(2) Consider feasibility of geophysical methods.

(3) Add area where fault approaches surface to soil gas/groundwater sampling area. same techniques.

(4) Need data on Miocene water disposal and conceptual modeling.

(5) Refine approaches.

(6) Look for cost estimates.

(7) Final proposed elements.

(8) Final costs for budget.

\section{NEPA Activities}

Similar to above, however add well-based geophysics to list of possible techniques. Might need kill fluids, or to plug back existing well as monitoring well (if one is available) above reservoir

\section{Off-structure or out of compartment migration of $\mathrm{CO}_{2}$ or brine as a result of elevated pressure into areas not controlled as part of the flood}

In EOR, injection is mostly balanced by extraction, so that the area of elevated pressure is of limited size, which has not in the past been of much concern. However, the prospect of areas where injection will now be for EOR (disposal only) has elevated concern within DEO and EPA about management of the size of the $\mathrm{CO}_{2}$ plume and the size of the area of elevated pressure. It would therefore be wise in a competitive proposal to document the pressure elevation in the reservoir but outside of the flood and the maximum extent of $\mathrm{CO}_{2}$ migration.

Several techniques are possible to document the two areas (elevated pressure and extent of $\mathrm{CO}_{2}$ ):

(1) Direct measurement though wells. Repeat measurement of bottom hole pressure under shut in conditions and measurement of fluid saturations via sampling or (in new wells with good open hole logs) logging. At both Soso and Hastings this could be done by drilling one or more future injectors early, and using them as observation wells for most of 2014-15 period before conversion to injection. (these are off structure or away from initial patterns?) 
(2) Model -matching, assuring that the ultimate fate of $\mathrm{CO}_{2}$ over 1000 years is constrained depends on good model-match during early stages of flood. Improve model - collect any needed data such as PVT, end point residual saturation, cap pressure, core porosity and permeability. (Do tar mats, ROZ areas or original water legs have a material impact on the real perm data? BEG needs to define these as part of the model when investigating plume growth beyond the original oil/gas zones) Add data needed to improve history match especially with regard to DOE expectation of tracking injected $\mathrm{CO}_{2}$ - injection and production profiles, logging program. Update model as needed with observations during flood. (flow model only as good as the static geo model)

(3) Indirect geophysical measurements - surface deformation via, tilt, GPS and InSAR, downhole tilt, repeat VSP or surface 2-D or 3-D though transects of the plume, to document maximum lateral extent. The choices at both sites will be limited because of previous activities, and at Soso by depth. (some historical subsidence issues in Hastings as evidenced by casing collapse in its history)

\section{Next Actions}

(1) Discuss with Denbury drilling short-term observation wells (future injectors drilled ahead of schedule) Possible? Need to make sure these hit the 2011 or 12 budget ahead of the planned work in 2013 or 2014, best argument is that they are accelerated wells that will be needed anyway.

(2) Discuss model situation with Denbury - What exists? Who will do this work? Ongoing deterministic model in Hastings, simplified, being developed by Denbury's Reservoir Simulation group, all in FB-A so far.

(3) Sensitivity/feasibility of using focused geophysics for plume and pressure tracking.

(4) Refine approaches

(5) Look for cost estimates

(6) Final proposed elements

(7) Final costs for budget 


\section{Gulf Coast Carbon Center - Report to Denbury on MVA Planning for FOA 15}

Report Type:

Report number :

Report title:

Completion Date:

Report Issue Date:

Submitting Organization:
Report and documentation of milestone completion C5.2.3.1

Draft Risk Assessment and MVA plan

December 15, 2009

April 11, 2010

Susan D. Hovorka, Principle Investigator, Gulf Coast Carbon Center Bureau of Economic Geology Jackson School of Geosciences

The University of Texas at Austin

Comment: Draft risk assessment and MVA plan noting site-specific data needs prepared by GCCC based on previous experience and available site-specific data. 


\title{
Phase I Task C5.2.3.1
}

\author{
Draft risk assessment and MVA plan
}

Prepared for:

Denbury Resources

\author{
Report by Susan D. Hovorka \\ April 11, 2010 \\ Bureau of Economic Geology \\ John A. and Katherine G. Jackson School of Geosciences \\ The University of Texas at Austin \\ Austin, Texas 78713-8924
}




\section{Table of Contents}

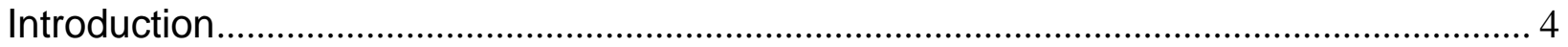

Goals of a Monitoring, Verification and Accounting Plan (MVA) ...................................... 4

Process for Preparing an MVA Plan .............................................................................. 4

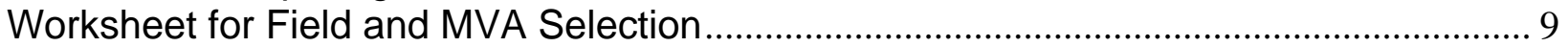

Tables

Table 1. Proposed monitoring program options ................................................................. 6

Table 2. Sources of expertise within the project showing highlights................................... 8

Table 3. Scoping spreadsheet for field selection and MVA program development............ 9 


\section{Introduction}

This report documents the status of planning and progresses for Task C1.5.4.1, Draft risk assessment and MVA plan. GCCC has prepared a list of site-specific data needs based on previous experience and available site-specific data. This data table describes the data needs needed to design an MVA plan, and requests information from Denbury on data availability for several field in consideration. It also solicits information on how the MVA needs will be evaluated, and discusses how the data will be used for achieving storage goals.

\section{Goals of a Monitoring, Verification and Accounting Plan (MVA)}

A Monitoring, Verification and Accounting (MVA) plan for each sequestration site will focus on assurance that identified risks are not occurring. This assurance program includes:

(1) assuring that the $\mathrm{CO}_{2}$ is contained in the designated trap (no spill out of reservoir);

(2) assuring that well completions have integrity to retain $\mathrm{CO}_{2}$ over the 1000 year time frame;

(3) assuring that the seal and the faults and fracture systems that cut it retain confining capacity after pressure depletion during production and pressure increase during the flood;

(4) and additional observations and activities above and beyond the normal $\mathrm{CO}_{2} \mathrm{EOR}$ operations that will allow interpretations to be made of confinement of the $\mathrm{CO}_{2}$ beyond the operational period.

\section{Process for Preparing an MVA Plan}

In order to prepare a detailed plan a number of activities will be performed in Phase I of the project. An effective and efficient MVA plan has to be based on the actual field and reservoir in which the sequestration will take place.

Prior to injection, Denbury will construct a geologic model of the reservoir using available wireline logs, core, seismic, and past production data, and simulate the interaction of injected $\mathrm{CO}_{2}$ with reservoir fluids. Reservoir characterization is undertaken to guide the flood design; this provides essential data to assure that the $\mathrm{CO}_{2}$ is effectively and efficiently contained within the reservoir (in production terms maximize sweep efficiency and oil contact area).

Well bore integrity is a major reservoir management activity. Denbury has began a comprehensive review to determine the condition of active, idle, and plugged and abandoned (P\&A) wells in the area to be flooded. Scout tickets and RRC W-3A P\&A records are evaluated to make sure that this process has been properly completed. Denbury will develop a plan to reenter about half of the P\&A wells, that will provide an opportunity to evaluate $3 / 4$ of the penetrations using a combination of cement bond, temperature, TNT or other wireline tools to determine and remediate, if needed, casing - borehole annular cement integrity prior to or during the flood. The integrity of P\&A wells will be determined by (1) comparing the P\&A records for wells that were re-entered with the actual condition of the wells, to determine if records are accurate; and (2) a site specific surveillance program using migration indicators in soil and groundwater using both ambient (oil, methane, salinity) and introduced $\left(\mathrm{CO}_{2}\right.$, stable isotopic, perfluorocarbon tracers) to assure that individual wells are performing correctly. The operational period for individual wells is $>15$ years. At the end of useful life Denbury will assure that producers and injectors are P\&A'd in accordance with approved $\mathrm{CO}_{2}$-specific procedures that should be mature at that time. 
As the flood starts, Denbury will track $\mathrm{CO}_{2}$ via daily to weekly monitoring of well head pressure, monthly measurement of produced fluids from each well using the production test facility, and collection of additional data that are then input into reservoir models to optimize the flood. Denbury will track $\mathrm{CO}_{2}$ for flood optimization via routine monitoring of bottom hole pressures during the initiation of the flood and routine monitoring of well head pressure to determine when to open and begin to produce the wells into the facility. Once production begins, monthly volumetric balances of produced fluids in conjunction with reservoir pressure measurements and other wireline measurements will be utilized to monitor the flood and location of the $\mathrm{CO}_{2}$. Surveillance methods may include, flowing and shut-in bottom hole pressure measurements, TNT (neutron) logs, thermal/spinner production logging and other tools that may be developed.

A review of literature and recommendations for MVA activities will be conducted to evaluate what is recommended for each field. There are several existing publications of potential recommended MVA activities such as; IPPC Special Report on Geologic Sequestration, World Resources International CCS guidelines, CCPII's Results from the CO2 Capture Projects Vol. III, and the National Energy Technology Laboratory (NETL) http://www.netl.doe.gov/technologies/carbon seq/core rd/mva.html), Interstate Oil and Gas Compact Commission report "Carbon Capture and Storage: A regulatory framework for states.

The Bureau of Economic Geology Gulf Coast Carbon Center (GCCC) will work with Denbury and a number of service companies and research organizations to develop a site specific MVA plan to augment normal best practices. The MVA plan will include the extent to which normal best practices can provide this confirmation, the extent (if any) to which they need to be augmented and to recommend monitoring systems that are fit- for-purpose.

Criteria that define fit-for-purpose include

(1) definitive data that retention for storage has occurred

(2) predictive data that storage is permanent ( $<1 \%$ migration over 1000 years)

(3) cost effective

(4) compatible with $\mathrm{CO}_{2}$-EOR practices

(5) durable and robust for monitoring over multi-decade time frame in active $\mathrm{CO}_{2}$ field environment

(6) quantitative and reportable

Some of the ranges of possibilities that will be considered for the MVA plan are shown in Table 1. 
Table 1. Proposed monitoring program options

\begin{tabular}{|c|c|}
\hline Goal & MVA techniques to be considered* \\
\hline $\begin{array}{l}\text { Assuring that the } \mathrm{CO}_{2} \text { is } \\
\text { contained in the designated } \\
\text { trap (no spill out of reservoir) }\end{array}$ & $\begin{array}{l}\text { Collection of injection data, pressure data and fluid } \\
\text { production. History matching production data using } \\
\text { reservoir simulator to document mass balance, } \\
\text { pressure conformance, and maximum extent of } \\
\text { plume. Additional data collection, such as as PFT } \\
\text { Geochemical Tracers to show injector-producer } \\
\text { flow and plume thickness, additional permanently } \\
\text { installed, wireline or slickline instruments (e.g. } \\
\text { thermal, acoustic, pulsed neutron), surface- } \\
\text { deployed geophysical techniques including VSP } \\
\text { azimuthal and walkaway surveys and time lapse 3- } \\
\text { D; conformance control via } \mathrm{CO}_{2} \text { foams or other } \\
\text { advanced reservoir management engineering }\end{array}$ \\
\hline $\begin{array}{l}\text { Assuring that well } \\
\text { completions and P\&A wells } \\
\text { have integrity post-closure to } \\
\text { retain } \mathrm{CO}_{2} \text { over the } 1000 \text { year } \\
\text { time frame. }\end{array}$ & $\begin{array}{l}\text { Assessment of historical well completion and P\&A } \\
\text { reports; reentry of selected wells to test accuracy } \\
\text { of historical reports, cement bond and casing } \\
\text { integrity logs; deconstruction and analysis of well } \\
\text { materials (as done by Schlumberger and CCP); } \\
\text { well surveillance during flood (noise, temperature, } \\
\text { pressure, fluid migration); above-zone pressure, } \\
\text { temperature, geochemical monitoring; emplaced } \\
\text { PFT to tag } \mathrm{CO}_{2} \text { to detect above zone or at surface; } \\
\text { time lapse 3-D survey looking for change above } \\
\text { zone, up-gradient-down gradient groundwater } \\
\text { monitoring, soil gas monitoring. }\end{array}$ \\
\hline $\begin{array}{l}\text { Assuring that the seal and } \\
\text { faults and fracture systems } \\
\text { that cut it retain confining } \\
\text { capacity after pressure } \\
\text { depletion during production } \\
\text { and pressure increase during } \\
\text { the flood. }\end{array}$ & $\begin{array}{l}\text { Collection of seal and geomechanical testing and } \\
\text { modeling to determine if either pressure drop } \\
\text { during production or pressure increase during } \\
\text { injection could damage seal, emplaced PFT to tag } \\
\mathrm{CO}_{2} \text { to detect cross-fault, above zone or at surface; } \\
\text { geochemical stability with } \mathrm{CO}_{2} \text {-water-interation; } \\
\text { evaluation of geologic and historical performance } \\
\text { of seal and faults during charge and production; } \\
\text { cross-faults and above-zone pressure, } \\
\text { temperature, or geochemical monitoring; time } \\
\text { lapse 3-D survey looking for change above zone; } \\
\text { up-gradient-down gradient groundwater monitoring, } \\
\text { soil gas monitoring. }\end{array}$ \\
\hline
\end{tabular}

* Site specific cost/value/feasibility assessment will be conducted and only a selection of techniques named above will be proposed for the final MVA plan.

As the geologic assessment, modeling, and engineering design advances, it will highlight additional uncertainties or remove potentially eliminate uncertainties that may affect storage assurance. We will use several risk assessment methods, consulting Denbury's in-house expertise, Quintessa FEPS data base (http://www.quintessa.org/CO 2 fepdb/PHP/frames.php), 
LBNL-UT certification framework, literature review, interview other current projects doing monitoring (e.g. Otway, Victoria, Australia, Ketzin, Potsdam, Germany, project at ADM plant Dekatur,II, BP's Insalah Project in Algeria), and expert interviews to formally list all the factors and uncertainties that could lead to failure to attain the expected level of long-term storage. Any significant additions to the list in the table above and a list of monitoring options will be added.

GCCC will invest significant effort into evaluation of the value based on the cost versus benefit of each monitoring tool. Value includes the ability of the tools to make the needed measurements to reach project goals, sensitivity at relevant conditions, durability and cost of maintenance/replacement, frequency of repeat, density of data collection, cost of each repetition, value of information in context of history matching a model or confirming non-detect. This evaluation will make substantive use of GCCC past field monitoring experience (Frio I, Frio II, SECARB Stacked Storage at Cranfield, SECARB Early at Cranfield, and SWP Phase II at SACROC). Each of these test projects has made significant advances in monitoring and provides lessons learned that will be used to meet this project's applied objectives. In addition, the GCCC team has been involved as reviewers and collaborators in many other projects, and will continue aggressive co-ordination with other groups within the Regional Carbon Sequestration Partnerships (RCSP), the US, and worldwide to bring new results to the project. Table 2 shows some of the resources and connections that have been drawn upon to develop the MVA plan. Denbury will review the recommendations of the GCCC evaluation and during working meetings the project team will determine best value tools will be selected for proposal in the final MVA plan. 
Table 2. Sources of expertise within the project showing highlights

\begin{tabular}{|c|c|c|}
\hline Expertise & Source & Nature of link \\
\hline Reservoir characterization & Denbury & $\begin{array}{l}\text { Provided to project as in-kind } \\
\text { contribution }\end{array}$ \\
\hline $\begin{array}{l}\text { Storage efficiency -best } \\
\text { practice }\end{array}$ & Denbury & $\begin{array}{l}\text { Provided to project as in-kind } \\
\text { contribution }\end{array}$ \\
\hline $\begin{array}{l}\text { Storage efficiency - } \\
\text { extended as needed for } \\
\text { CCS }\end{array}$ & GCCC/Denbury & $\begin{array}{l}\text { In-zone monitoring experience } \\
\text { from Frio test, Phase I Cranfield } \\
\text { enhanced reservoir surveillance } \\
\text { program, Phase III Cranfield Field } \\
\text { test underway. Numerous other } \\
\text { CCS specific as well as service } \\
\text { company approaches available, } \\
\text { contacts through IEA GHGR\&D } \\
\text { program monitoring working } \\
\text { group; RCSP MVA Working Group }\end{array}$ \\
\hline $\begin{array}{l}\text { Well-bore integrity - best } \\
\text { practice }\end{array}$ & Denbury & $\begin{array}{l}\text { Provided to project as in-kind } \\
\text { contribution }\end{array}$ \\
\hline $\begin{array}{l}\text { Well-bore integrity- } \\
\text { advanced }\end{array}$ & $\begin{array}{l}\text { GCCC-Sandia } \\
\text { Technologies }\end{array}$ & $\begin{array}{l}\text { Expertise via Carbon capture } \\
\text { Project (CCP) } \\
\text { http://www.CO } 2 \text { captureproject.org/; } \\
\text { contacts through IEA GHGR\&D } \\
\text { program well-bore integrity } \\
\text { working group }\end{array}$ \\
\hline Above -zone Monitoring & $\begin{array}{l}\text { GCCC/Sandia } \\
\text { Technologies }\end{array}$ & $\begin{array}{l}\text { Chemical monitoring -Frio, } \\
\text { Pressure Monitoring SECARB II } \\
\text { and III at Cranfield }\end{array}$ \\
\hline Ground water monitoring & GCCC & $\begin{array}{l}\text { Experience through recently } \\
\text { completed SWP SACROC } \\
\text { program, test at Cranfield } \\
\text { underway. }\end{array}$ \\
\hline Soil gas monitoring & Denbury, GCCC & $\begin{array}{l}\text { Baseline underway at Oyster } \\
\text { Bayou; GCCC method } \\
\text { improvement at Brackenridge field } \\
\text { station; Cranfield Phase III. } \\
\text { Connection to ZERT, RCSP } \\
\text { monitoring working group, } \\
\text { numerous vendors }\end{array}$ \\
\hline
\end{tabular}




\section{Worksheet for Field and MVA Selection}

The mechanism for accomplishing the site selection and site specific risks will be via an inperson meeting, at which Denbury and GCCC staff will evaluate the candidate field to determine the lowest risk and highest chance of success. The evaluation table is shown in figure 3.

Table 3. Scoping spreadsheet for field selection and MVA program development

\begin{tabular}{|c|c|c|c|c|}
\hline & & & & \\
\hline Characteristics & Details & $\begin{array}{l}\text { importance } \\
\text { to success } \\
\text { of project } \\
5=\text { very } \\
\text { important } \\
\text { to } 1=\text { not at } \\
\text { all } \\
\text { important }\end{array}$ & 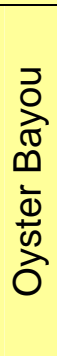 & 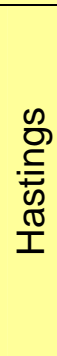 \\
\hline Match of injection area to injecti & n volume & & & \\
\hline $\begin{array}{l}\text { Number of patterns needed for } \\
\text { planned } \mathrm{CO}_{2} \mathrm{~A} \text { volumes }\end{array}$ & & & & \\
\hline Timing/volumes of $\mathrm{CO}_{2} \mathrm{~A}$ available & & & & \\
\hline $\begin{array}{l}\text { Temporal match of } \mathrm{CO}_{2} \text { available } \\
\text { patterns }\end{array}$ & $\begin{array}{l}\text { Will } \\
\mathrm{CO}_{2} \text { be } \\
\text { injected } \\
\text { in a new } \\
\text { area? } \\
\text { (no } \\
\text { previous } \\
\mathrm{CO}_{2} \text { ) }\end{array}$ & & & \\
\hline $\mathrm{CO}_{2}$ accounting & & & & \\
\hline $\begin{array}{l}\text { Quantify and report } \mathrm{CO}_{2} \text { injected, } \\
\text { recycled }\end{array}$ & $\begin{array}{l}\text { Who is } \\
\text { handing } \\
\text { this part } \\
\text { of } \\
\text { MVA? }\end{array}$ & & & \\
\hline $\begin{array}{l}\text { Quantify water, oil, gas volumes } \\
\text { extracted }\end{array}$ & & & & \\
\hline $\begin{array}{l}\text { Handing } \mathrm{CO}_{2}-\text { separator efficacy, } \\
\text { line leakage, venting during } \\
\text { handing }\end{array}$ & & & & \\
\hline $\begin{array}{l}\text { Frequency, density, quality of data } \\
\text { for } \mathrm{CO}_{2} \text { accounting }\end{array}$ & & & & \\
\hline $\begin{array}{l}\text { Potential to improve accounting } \\
\text { data beyond current practices }\end{array}$ & & & & \\
\hline
\end{tabular}

\section{NEPA risks}




\begin{tabular}{|l|l|l|l|l|}
\hline $\begin{array}{l}\text { Minimum contentious or litigious } \\
\text { public }\end{array}$ & & & & \\
\hline Wetlands & & & & \\
\hline No endangered species habitat & & & & \\
\hline $\begin{array}{l}\text { No historical features, parks, } \\
\text { residential area problems }\end{array}$ & & & & \\
\hline
\end{tabular}

Model reservoir block to account for $\mathrm{CO}_{2}$ distribution

\begin{tabular}{|l|l|l|l|l|}
\hline 3-D seismic & & & & \\
\hline Cores and core analysis & & & & \\
\hline Historical production data & & & & \\
\hline Good PVT data & & & & \\
\hline Detailed geologic model & & & & \\
\hline Detailed flow model & & & & \\
\hline
\end{tabular}

\section{Available MVA data to history match}

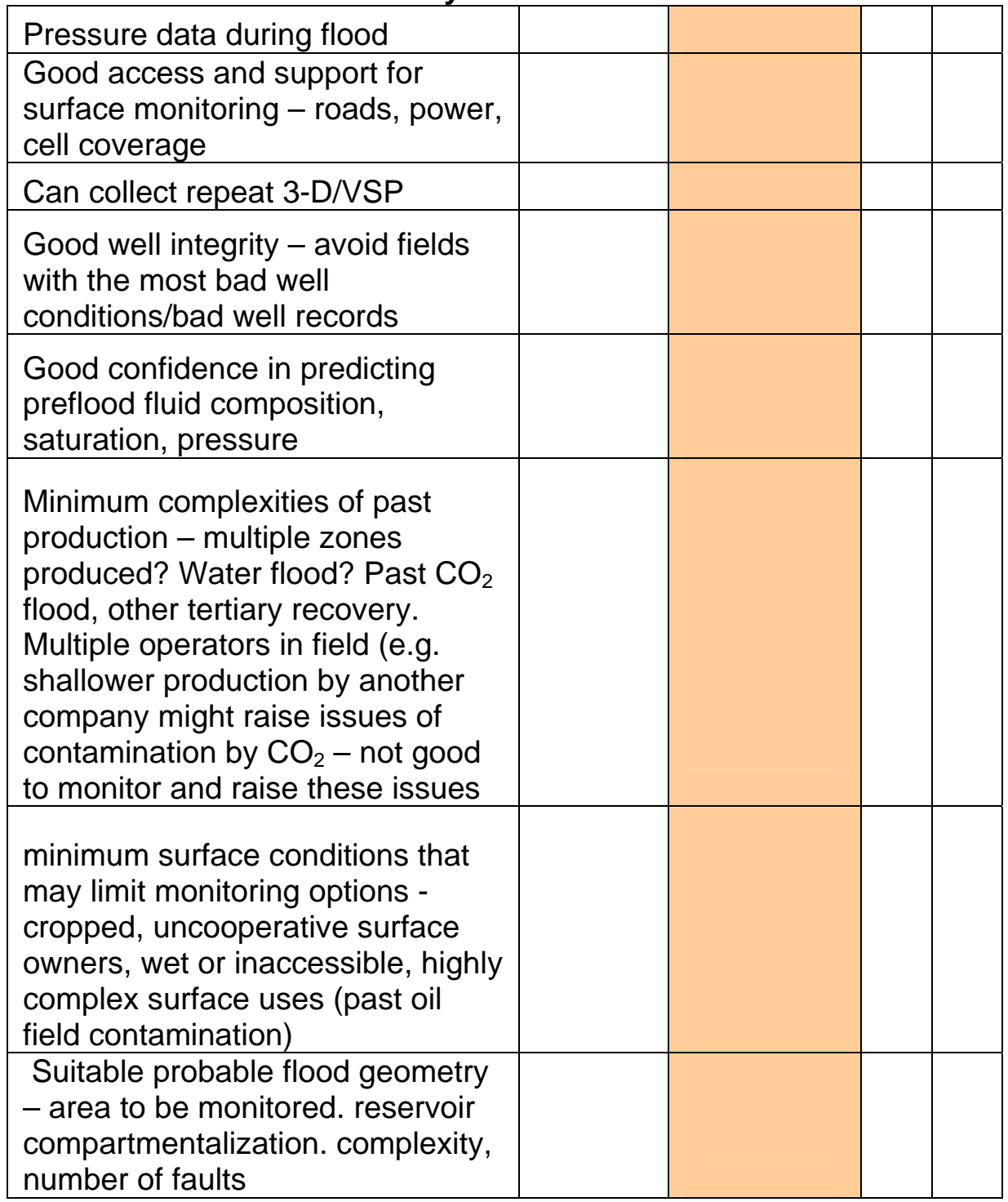




\section{Some additional questions and key points to consider as we plan MVA strategy:}

Develop MVA approach - Collect data to reduce perception of risk (by $\mathrm{CO}_{2}$ supplier \& DOE)

What are the biggest unknowns? $\mathrm{CO}_{2}$ use per pattern?

Compartmentalization? Miscibility? Pressure? In DOE -speak these would be described as capacity and trapping mechanism

What shall we do to show well integrity?

How do we show faults are sealing especially over geologic time?

Monitoring should be used to confirm a model - who will do this model?

Risk Assessment approach?

How to coordinate monitoring with field development - possible dual use (future injectors/producers used as monitoring wells) to limit cost. Dual use of water make-up wells?

Who are stakeholders and what is process by which they will provide feedback for Phase II proposal?

In Phase II budget -Who will do the monitoring field work - how much done by Denbury or other contractors? 


\section{Gulf Coast Carbon Center - Report to Denbury on MVA Planning for FOA 15}

Report Type:

Report number :

Report title:

Completion Date:

Report Issue Date:

Submitting Organization:

Comment:
Report and documentation of milestone completion C5.2.3.3

Final MVA plan and detailed budget

March 22, 2010

April 11, 2010

Susan D. Hovorka, Principle Investigator, Gulf Coast Carbon Center Bureau of Economic Geology Jackson School of Geosciences The University of Texas at Austin

Report presented here is after Denbury review and revision as of April 4, 2010. 
Phase I Task C.5.2.3.3

Final MVA Plan and Detailed Budget

Prepared for:

Denbury Resources

Report by Susan D. Hovorka

April 11, 2010

Bureau of Economic Geology

John A. and Katherine G. Jackson School of Geosciences

The University of Texas at Austin

Austin, Texas 78713-8924 


\section{Table of contents}

Introduction to MVA plan

Figures

Figure 1. Stratigraphic section

Figure 2. West Hastings Fault Block B and C Frio type log showing multiple

injection zones

Figure 3. Compartmentalization of the West Hastings reservoir by the main fault

on the east side of the field and a series of cross faults

Figure 4 Development plan of $\mathrm{CO}_{2}$ flood in West Hastings field ............................ 13

Figure 5. Upper Frio patterns in fault blocks $B$ and $C$............................................. 17

Figure 6. Estimated CO2 purchase and recycle volumes ....................................... 18

\section{Tables}

Table 1. Documents considered in preparation of the research monitoring, verification and accounting (MVA) program .................................................. 4

Table 2. MVA plan responsibilities .............................................................. 5

Table 3. MVA project phases aligned with capture facility phases...................... 7

Table 4. Field Storage Capacity (Fault block $B$ and $C$ ) based on volume-for

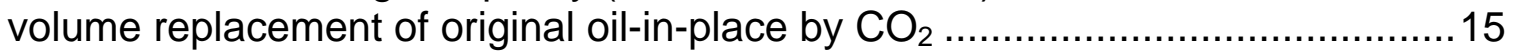

Table 5. Results of core-based permeability form fault block A ....................... 16

Table 6. Data for modeling and likely data source ........................................23

Table 7. Budget

in Excel 


\section{Introduction to MVA plan}

$\mathrm{CO}_{2}$ injected for EOR is the best known and therefore the lowest risk process available for geologic sequestration. The effectiveness of the seal and trapping structure in confining the fluids (oil and gas) over geologic time has been demonstrated directly by hydrocarbon accumulation. Injectivity and effective capacity have been documented by previous fluid handling during production and water injection. Permitting and negotiation of land and pore space access follow well known processes with low risk. Injection of natural $\mathrm{CO}_{2}$ into West Hastings field will be underway in fault block $A$ several years prior to beginning injection of anthropogenic $\mathrm{CO}_{2}\left(\mathrm{CO}_{2}-\mathrm{A}\right)$ injection into West Hastings fault block $\mathrm{B}$ and $\mathrm{C}$; this will provide a strong experience base on which to rely to document $\mathrm{CO}_{2}$ retention. Previous studies focused on sequestration in an EOR context provide precedents for MVA design. These include the Weyburn project conducted at EnCana's flood in Saskatchewan, the BEG-led study as part of the Southwest Regional Carbon Sequestration Partnership (SWP) of the results of more than 30 years of $\mathrm{CO}_{2}$ injection from EOR at Kinder Morgan's SACROC Field in Scurry County Texas, and the currently underway BEG led multi-institutional study of large volume ( $>1$ Million ton/year) injection at Denbury's Cranfield Field, Adams-Franklin Counties, Mississippi.

Currently, $\mathrm{CO}_{2}$ from any source injected for $\mathrm{CO}_{2}$ enhanced oil recovery (EOR) is regulated under UIC class II. In Texas, the Railroad Commission has primacy and requires a number of monitoring, accounting, and reporting activities to bring the field under flood and which are required periodically during the flood. Protection of groundwater resources (underground sources of drinking water [USDW]) is the main focus of the class II regulations. In addition, Denbury has developed, through a decade of experience with EOR in the Gulf Coast, a number of commercial best practices that are used to control the subsurface movement of $\mathrm{CO}_{2}$ and manage elevated pressure in order to optimize the performance of the flood and minimize cost and risks. It is unclear if additional monitoring and reporting activities will be required for EOR in the future, or to what the extent of these activities would be. The goals of the research monitoring, verification and accounting (MVA) program proposed here are, therefore, based on uniting elements of the existing regulatory monitoring requirements and existing best practices with a number of proposed and suggested processes that are being considered for future application to $\mathrm{CO}_{2}$ injected under various possible future regulatory or credit trading conditions. Table 1 shows documents with proposed and suggested future MVA processes reviewed during compilation of this research MVA plan.

Table 1. Documents considered in preparation of the research monitoring, verification and accounting (MVA) program

\begin{tabular}{|l|l|l|}
\hline Document & Source & Status \\
\hline TX RRC rules for EOR & $\begin{array}{l}\text { Fluid injection into productive reservoirs } \\
\text { TAC Title16 part1 Chapter3 Rule 3.46 }\end{array}$ & in effect \\
\hline $\begin{array}{l}\text { Denbury Commercial Best } \\
\text { Practices }\end{array}$ & Denbury & in effect \\
\hline EPA Draft Rules & $\begin{array}{l}\text { http://www.epa.gov/safewater/uic/wells s } \\
\text { equestration.html } \\
\text { Comment period closed. }\end{array}$ & $\begin{array}{l}\text { Proposed } \\
2008\end{array}$ \\
\hline $\begin{array}{l}\text { TX RRC draft rules for injection } \\
\text { for the purpose of geological } \\
\text { storage in productive formations } \\
\text { and in formation directly above }\end{array}$ & $\begin{array}{l}\text { TAC Chapter 16 Chapter 5 Draft Rules } \\
\text { Released March 26, 2010 } \\
\text { Out for comment. }\end{array}$ & $\begin{array}{l}\text { Proposed } \\
2010\end{array}$ \\
\hline
\end{tabular}


Appendix D: Final MVA Plan And Detailed Budget

\begin{tabular}{|l|l|l|}
\hline and below productive formations & & \\
\hline World Resources Institute CCS & http://www.wri.org/project/carbon-capture- & $\begin{array}{l}\text { NGO } \\
\text { overview } \\
\text { Guidelines Report }\end{array}$ \\
& sequestration \\
& & tocumen \\
\hline
\end{tabular}

The current requirements for Class II injection and commercial best practices in managing a $\mathrm{CO}_{2}$ flood are the foundations of an MVA plan. No federal regulatory agency has proposed a change in rules for $\mathrm{CO}_{2} \mathrm{EOR}$, so the current regulations that govern injection of anthropogenic $\mathrm{CO}_{2}$ for EOR (Fluid injection into productive reservoirs under TAC Title16 part 1 Chapter3 Rule 3.46) are presumed to be those regulating the project injection. In fact, the Texas proposed rules anticipate the continued use of Class II for $\mathrm{CO}_{2}$ EOR. It is however, possible under some scenarios that future rules for handling $\mathrm{CO}_{2}$ could result in a change of standards for MVA applied to EOR, for example to avoid EOR counting as a source of emissions. The research goals set for this plan are (1) to test the extent to which current commercial practices (as required by regulations for fluid injection into productive reservoirs under TAC Title16 part 1 Chapter 3 Rule 3.46 plus commercial best practices) can meet possible future MVA expectations; (2) to test novel MVA approaches to see if they increase confidence and otherwise add value to an EOR + sequestration project; and (3) provide adequate budget and flexibility in case regulatory requirements change prior to the end of the project period.

A team comprised of Denbury, Praxair, and BEG GCCC will conduct the research MVA plan. Each named group will have subcontractors working for them; these subcontractors are not named in the proposal, however costs are based on quotes and extensive past experience with contracting similar services in similar settings. Costs include normal percentage of field work related costs beyond the minimum costs, and also reflect cost uncertainties in labor, fuel, commodities over the project time period.

Table 2. MVA plan responsibilities

\begin{tabular}{|l|l|l|l|}
\hline Group & Responsibility & Reporting & Budget \\
\hline Denbury & $\begin{array}{l}\text { Conduct commercial } \\
\text { MVA activities, } \\
\text { remediation in } \\
\text { response to any } \\
\text { evidence of non- } \\
\text { containment }\end{array}$ & $\begin{array}{l}\text { Report results to } \\
\text { document the } \\
\text { effectiveness of these } \\
\text { activities }\end{array}$ & $\begin{array}{l}\text { Commercial and } \\
\text { remediation activities } \\
\text { are done as part of } \\
\text { commercial project, } \\
\text { not in proposal budget }\end{array}$ \\
\hline Denbury & $\begin{array}{l}\text { Support research } \\
\text { MVA activities where } \\
\text { these activities fit in } \\
\text { with Denbury's core } \\
\text { competency, for } \\
\text { example contract } \\
\text { geophysical activities, } \\
\text { review BEG results } \\
\text { prior to submission }\end{array}$ & $\begin{array}{l}\text { Report results though } \\
\text { BEG research team }\end{array}$ & $\begin{array}{l}\text { 20\% Denbury cost } \\
80 \% \text { Federal cost. } \\
\text { Characterization data } \\
\text { for reservoir and fault } \\
\text { modeling studies is } \\
\text { provided as in kind } \\
\text { (no cash) cost share. }\end{array}$ \\
\hline $\begin{array}{l}\text { Sandia Technologies } \\
\text { LLC }\end{array}$ & $\begin{array}{l}\text { Support research } \\
\text { MVA activities where } \\
\text { these activities require } \\
\text { extensive supervision } \\
\text { (e.g. specialized MVA }\end{array}$ & $\begin{array}{l}\text { Contribute results to } \\
\text { research plan through } \\
\text { BEG team }\end{array}$ & $\begin{array}{l}20 \% \text { Denbury cost } \\
80 \% \text { Federal cost }\end{array}$ \\
\hline
\end{tabular}




\begin{tabular}{|c|c|c|c|}
\hline & $\begin{array}{l}\text { surveys and } \\
\text { equipment } \\
\text { installation) }\end{array}$ & & \\
\hline $\begin{array}{l}\text { Bureau of Economic } \\
\text { Geology }\end{array}$ & $\begin{array}{l}\text { Develop reservoir and } \\
\text { area of elevated } \\
\text { pressure for prediction } \\
\text { of pressure and fluid } \\
\text { evolution during and } \\
1000 \text { years beyond } \\
\text { project period, risk } \\
\text { assessment, MVA } \\
\text { research design, } \\
\text { oversight of research } \\
\text { data collection, } \\
\text { conduct near surface } \\
\text { data collection, } \\
\text { integration of research } \\
\text { results }\end{array}$ & $\begin{array}{l}\text { Report results of } \\
\text { modeling and risk } \\
\text { assessment, submit } \\
\text { updated MVA plans } \\
\text { and costs at each } \\
\text { phase, report interim } \\
\text { results, and at project } \\
\text { conclusion report } \\
\text { integrated MVA. } \\
\text { Results to be } \\
\text { reviewed by Denbury } \\
\text { and submitted by } \\
\text { DOE }\end{array}$ & $\begin{array}{l}\text { 20\% Denbury cost } \\
80 \% \text { Federal cost }\end{array}$ \\
\hline $\begin{array}{l}\text { Bureau of Economic } \\
\text { Geology }\end{array}$ & $\begin{array}{l}\text { Lab PVT tests to } \\
\text { document } \\
\text { fractionation and } \\
\text { effectiveness of PFT } \\
\text { in complex fluid } \\
\text { system } \\
\text { Under study }\end{array}$ & $\begin{array}{l}\text { Report to Praxair and } \\
\text { Denbury and to final } \\
\text { report }\end{array}$ & $\begin{array}{l}20 \% \text { Praxair cost } 80 \% \\
\text { Federal cost }\end{array}$ \\
\hline Praxair Seeper Trace & $\begin{array}{l}\text { Inject PFT, analyze } \\
\text { field samples and } \\
\text { research samples, } \\
\text { field collection of } \\
\text { samples at P\&A wells } \\
\text { using Seeper trace } \\
\text { technology } \\
\text { Subject to Denbury } \\
\text { approval }\end{array}$ & $\begin{array}{l}\text { Report interim and } \\
\text { final results each type } \\
\text { of test }\end{array}$ & $\begin{array}{l}20 \% \text { Praxair cost } 80 \% \\
\text { Federal cost }\end{array}$ \\
\hline
\end{tabular}

In the following sections, we define: (1) the schedule of activities, (2) the current state of site characterization and capacity assessment, (3) the current assessment of uncertainties that lead to assessment of risks and guide the research MVA plan, (4) the commercial monitoring activities that provides the standard for the research MVA plan, and (5) the research MVA plan that tests the effectiveness of the commercial plan and several novel approaches that may extend the level of confidence beyond the commercial activities. This is followed by a scope of work detail in the tasks divided by project phase and task number with a reporting plan, a cost justification, experience of key participants, and budget.

\section{Schedule of Phase 2 activities}

MVA activities are coordinated to match the stages of development of the capture facility as shown in Table 3. 
Table 3 MVA project phases aligned with capture facility phases.

\begin{tabular}{|c|c|c|}
\hline Phase & $\begin{array}{l}\text { Capture } \\
\text { Facility Phase }\end{array}$ & MVA phase \\
\hline $2 \mathrm{~A}$ & Design* & $\begin{array}{l}\text { Site characterization including initial field measurements, } \\
\text { predictive fluid flow and pressure modeling, risk } \\
\text { assessment, tool down-selection, experience increase as a } \\
\text { result of ongoing injection in fault block A and early } \\
\text { measurements in fault blocks B and C, learning from other } \\
\text { projects elsewhere }\end{array}$ \\
\hline 2A Decision & $\begin{array}{l}\text { Go/No Go } \\
\text { decision }\end{array}$ & $\begin{array}{l}\text { Revised MVA conceptualization and reallocation of funds as } \\
\text { needed to coordinate with revised build out plan }\end{array}$ \\
\hline 2B & $\begin{array}{l}\text { Capture facility } \\
\text { construction }\end{array}$ & $\begin{array}{l}\text { Fault blocks B and C injection, production, monitoring well } \\
\text { permitting, site preparation (roads, separation facility } \\
\text { expansion), well workover and new drills in patterns } \\
\text { including selected advanced patterns, baseline data on soil } \\
\text { gas, groundwater, and subsurface pressure, fluid } \\
\text { composition and rock property data collected, baseline } \\
\text { geophysics and well logging, input data into predictive } \\
\text { model, revised risk assessment. }\end{array}$ \\
\hline 2B Decision & $\begin{array}{l}\text { Go/No Go } \\
\text { decision }\end{array}$ & $\begin{array}{l}\text { Revised MVA conceptualization and reallocation of funds as } \\
\text { needed to coordinate with revised build out plan }\end{array}$ \\
\hline $2 \mathrm{C}$ & $\begin{array}{l}\text { Demonstration } \\
\mathrm{CO}_{2} \text { production } \\
\text { from capture } \\
\text { facility }\end{array}$ & Anthropogenic $\mathrm{CO}_{2}$ injection, time-laps MVA data collection \\
\hline 2C Overview & & $\begin{array}{l}\text { Evaluation of results of MVA program, revised model runs } \\
\text { showing model match, comparing the effectiveness of the } \\
\text { commercial program to the research program in } \\
\text { documenting effectiveness and permanence of storage, and } \\
\text { recommendations for future MVA at } \mathrm{CO}_{2} \text { EOR settings. }\end{array}$ \\
\hline
\end{tabular}

${ }^{\star}$ Commercial proprietary non-funded data utilized to refine fluid flow and pressure modeling may be withheld from public information.

\section{A Design Phase}

The lead tasks of the design phase are integration of commercial site characterization data followed by predictive fluid flow and pressure modeling, and improved description of stress conditions on faults, leading to an improved assessment of risk of non-retention. Denbury is already well along on commercial development of Hastings Field for $\mathrm{CO}_{2}$ EOR flood into the northern fault block of West Hastings Field, fault block A. Prior to anthropogenic $\mathrm{CO}_{2}$ availability, injection using natural $\mathrm{CO}_{2}$ from Jackson Dome will be used to develop the flood into West Hastings Field fault block $A$. This experience will greatly decrease uncertainties in developing fault blocks $B$ and $C$, which development is scheduled to begin flood at the about the same time as anthropogenic $\mathrm{CO}_{2}\left(\mathrm{CO}_{2}-\mathrm{A}\right)$ is available. Therefore, prior to $\mathrm{CO}_{2}-\mathrm{A}$ injection, we expect improvements in knowledge of effective ways to manage the numerous wells, pressure, and flow in the field. As part of this effort, Denbury may start brine injection into fault block B and C, allowing collection of some early measurements of connection or isolation of fault block $A$ from fault blocks $B$ and $C$. Because the West Hastings Field is an ongoing EOR operation, it is expected that a NEPA CX or a waiver will be obtainedto begin tests to determine sensitivity and feasibility of proposed soil gas, groundwater, and well-bore integrity methods. BEG has planned several monitoring wells to determine the current pressure distribution during this phase. Any adjustments needed to match commercial field development to the $\mathrm{CO}_{2}-$ A injection plan(s) will be accommodated. 
Appendix D: Final MVA Plan And Detailed Budget

In addition, learning from other projects conducted elsewhere as part of DOE's and international programs, as well as reliance on Denbury's experience in other fields will be part of the design phase. At the end of the phase, BEG, in consultation with Denbury, will prepare a report containing an updated risk assessment, modifications recommended in MVA system, and corresponding adjustments in cost.

\section{B Construction Phase}

In this phase, preparation for injection of $\mathrm{CO}_{2}-\mathrm{A}$ into fault blocks $\mathrm{B}$ and $\mathrm{C}$ will be completed as part of Denbury's commercial field development operations. Injection, production, and monitoring wells will be permitted through the TX RRC. Site preparation; well workovers and new drills in patterns, including selected wells in the above zone monitoring interval (AZMI) will be used as access points to monitor ahead of the active injection. Baseline data on soil gas, groundwater, and subsurface pressure, fluid composition and rock properties will be collected and input into a predictive model, allowing a revised risk assessment. Baseline geophysics and baseline well logging will be completed prior to initiation of the flood. In addition, BEG will complete a laboratory test of the feasibility and best methods of using Perfluorocarbon Tracers (PFT) in the complex fluid environment. At the end of the phase, BEG in consultation with Denbury will prepare a report containing a revised MVA conceptualization and reallocation of funds as needed to coordinate with the revised build out plan.

\section{C Demonstration}

During this phase, it is anticipated that $\mathrm{CO}_{2}-\mathrm{A}$ will be available from the capture facility. The availability of natural $\mathrm{CO}_{2}$ will allow flexible staging, as any source of $\mathrm{CO}_{2}$ can be used to demonstrate containment. As injection starts, the commercial monitoring program will track the $\mathrm{CO}_{2}$ injected, the $\mathrm{CO}_{2}$ recycled, and the performance of the reservoir and wells in retaining $\mathrm{CO}_{2}$. The research program will collect time-lapse data testing alternative and possibly high-resolution techniques for documenting that the $\mathrm{CO}_{2}$ is retained in the injection zone and in the predicted flood area, and that pressure is below that determined to be safe. At the end of this phase, BEG, in consultation with Denbury, will prepare a report evaluating the results of the research MVA program, revised model runs showing model match, comparing the effectiveness of the commercial program to the research program in documenting effectiveness and permanence of storage. Recommendations for future MVA at EOR settings will be prepared.

The research monitoring program will end at the end of the demonstration phase. The objective of the research MVA program is to increase confidence in commercial monitoring programs and in the permanence of $\mathrm{CO}_{2}-\mathrm{A}$ storage.

\section{Initial characterization and capacity assessment}

In this section we review the current state of site characterization and capacity assessment, emphasizing the current assessment of uncertainties that lead to assessment of risks and guide the research MVA plan.

\section{Characteristics of the West Hastings Frio injection reservoir}

The Frio Formation of West Hastings Field is well characterized as an injection zone, and sufficient data are currently available to confirm confinement, injectivity, and storage 
capacity. The Anahuac Formation provides confinement at the top of the reservoir (Figure 1). This unit is a regionally extensive transgressive dark mudstone $>500 \mathrm{ft}$ thick. The seal properties of the Anahuac were studied as part of the Frio Brine pilot, and show that this formation is an excellent seal. Miocene strata provide redundant seals above the reservoir, which is the proposed location for the above-zone monitoring interval (AZMI). The base of the Frio Formation is defined by additional shale-sandstone sequences. Multiple sands in both the upper and lower Frio formation will be flooded as part of the Fault Block B and C development plan.

Regionally fluvial, strandplain, and deltaic sandstones of the Oligocene Frio Formation extend across the Gulf Coast Basin from the Texas-Mexico border to just west of the Texas-Louisiana border. Two sandstones of the upper Frio Formation were tested and found favorable for monitoring and for sequestration by the Bureau's Frio brine pilot test east of Houston. The Frio Formation at West Hastings field is composed of a number of sandstones separated by shales (Figure 2). Multiple sandstones are productive within the field and will serve as the injection reservoir. A major fault serves as the updip limit of the reservoir. Differences in the historic oil water-contact provide evidence that this fault is sealing. In addition, the reservoir is partly compartmentalized by cross faults (Figure 3). Fluvial sandstones of the Frio Formation, and salt deformation causing faulted structural closures are abundant along the Gulf Coast; knowledge about reservoir performance is high as is confidence in trapping. In addition to the natural trapping of large amounts of hydrocarbon beneath the Anahuac Formation, further confidence is provided by the widespread permitting of this unit as a confining system for Class I hazardous and non-hazardous permits (Kreitler, et al, 1990). 
Figure 1. Stratigraphic section

\begin{tabular}{|c|c|c|c|}
\hline$\frac{2}{5}$ & $\frac{8}{4}$ & $\begin{array}{l}\text { RIOGAMNDE } \\
\text { EMBAVMENT }\end{array}$ & $\begin{array}{l}\text { S. LOUISIANA. } \\
\text { JSTON EMBAYMENT, } \\
\text { SAN MARCOS AFCH }\end{array}$ \\
\hline$\frac{k^{2}}{3}$ & & Plelstocene & Plelstocene \\
\hline \multirow{18}{*}{ 旁 } & d & Pliocene & Pliccene \\
\hline & \multirow{3}{*}{$\frac{z}{c}$} & Upper Miccene & Upper Miccene \\
\hline & & Middle Milocene & Mididie Miccene \\
\hline & & Lower Miccene & Lower Miccene \\
\hline & \multirow{4}{*}{ 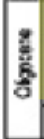 } & Anahuae & Anahesac \\
\hline & & Frio & Frio \\
\hline & & 然 & Hackberry \\
\hline & & Vicksburg & Vicksburg \\
\hline & \multirow{8}{*}{ है } & Jackson & Jackson \\
\hline & & Yegua & Yegua \\
\hline & & Cook Mountain & Cook Mountain \\
\hline & & Sparta & Sparta \\
\hline & & Weches & Weches \\
\hline & & Queen City & Queen City \\
\hline & & Reklaw & Rewlaw \\
\hline & & Carrizo & Cearrizo \\
\hline & \multirow{2}{*}{$\frac{2}{8}$} & Wilcox & Wilcox \\
\hline & & Midway & Midway \\
\hline \multirow{15}{*}{ 总 } & \multirow{7}{*}{$\frac{2}{5}$} & Etecandido & Navarro \\
\hline & & Olmos & \multirow{3}{*}{ Tayylor } \\
\hline & & Sen Milguel & \\
\hline & & Anscacho Serpentine & \\
\hline & & Austin & Austin \\
\hline & & Eagle Ford & Eagle Ford \\
\hline & & calger frota & Woodbine \\
\hline & \multirow{6}{*}{ 点 } & Buda & Buda \\
\hline & & Del Rio & Del Rio \\
\hline & & Ceorgetown & Georgetown \\
\hline & & Edwearde $/ \begin{array}{c}\text { Sluart } \\
\text { City }\end{array}$ & Edwards / Sluart \\
\hline & & Glen Rose & Glen Rose \\
\hline & & Pearsall & Pearsall \\
\hline & \multirow{2}{*}{$\frac{\frac{5}{2}}{\mathrm{~g}}$} & Sligo & Slige \\
\hline & & Hosston & Hassten \\
\hline \multirow{6}{*}{$\frac{0}{3}$} & \multirow{5}{*}{$\frac{\overline{3}}{3}$} & Cotton Valley & Colton Valley \\
\hline & & Gilmer & Gilmer \\
\hline & & Buckaner & Bucknar \\
\hline & & Smackovor & Smackovor \\
\hline & & Norphlot & Norphlet \\
\hline & $\underline{2}$ & $\begin{array}{l}\text { Louann Salt } \\
\text { Eagle Mills }\end{array}$ & $\begin{array}{l}\text { Lousnn Salt } \\
\text { Eagle Mills }\end{array}$ \\
\hline$\alpha$ & & Ouschits Facios & Ouachita Facios \\
\hline
\end{tabular}


Figure 2. West Hastings Fault Block B and C Frio type log showing multiple injection zones

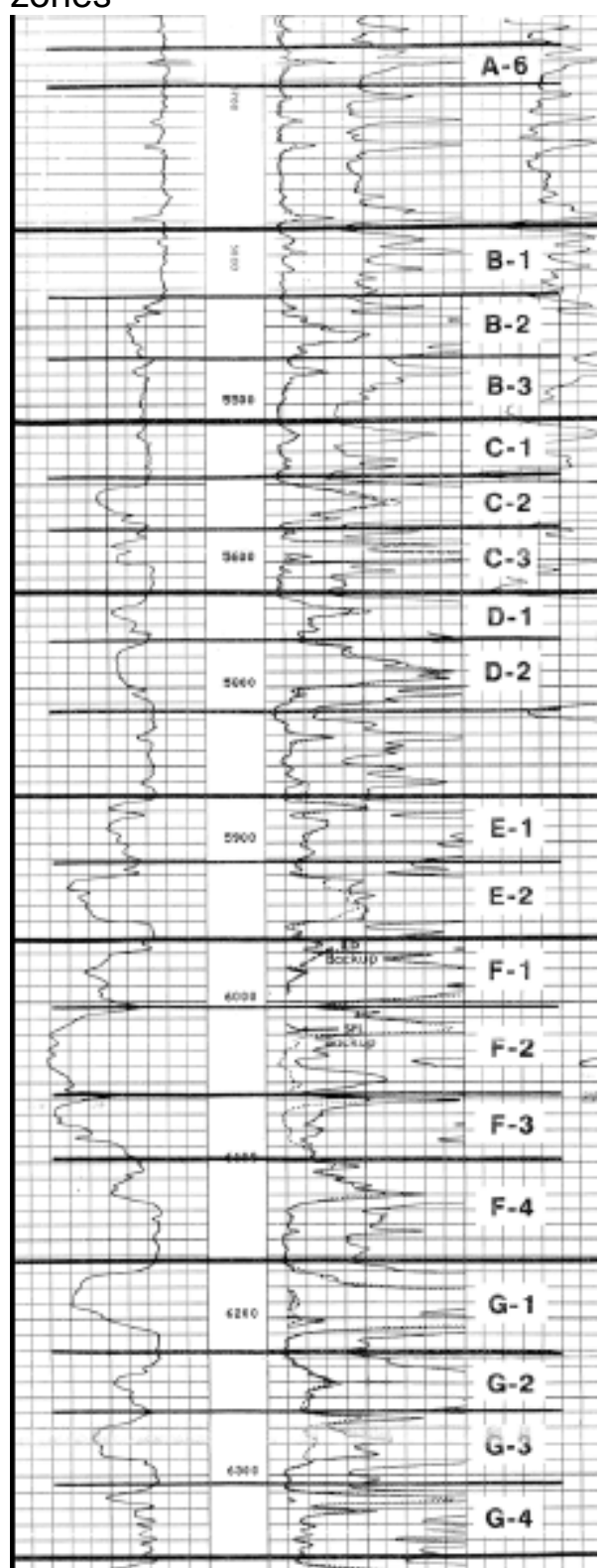


Figure 3. Compartmentalization of the West Hastings reservoir by the main fault on the east side of the field and a series of cross faults

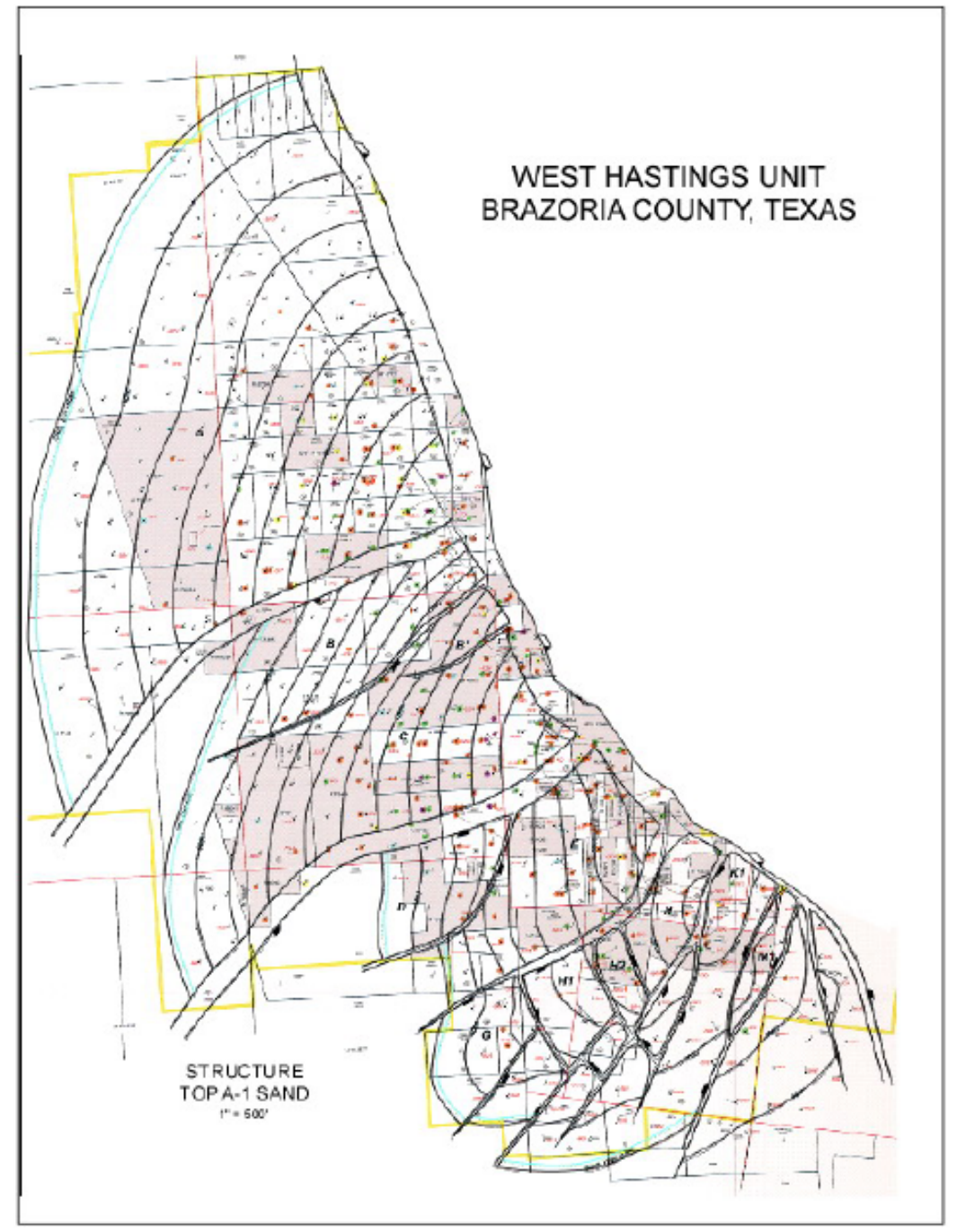

Denbury plans to develop the field in several stages (Figure 4), starting in 2010 with block $A$ at the north end of the field. Injection of $\mathrm{CO}_{2}-\mathrm{A}$ is planned to be into productive intervals of the Frio Formation into the $B$ and $C$ fault blocks of the reservoir because that area of the field will be first undergoing injection at the time when capture is underway. 
Figure 4 Development plan of $\mathrm{CO}_{2}$ flood in West Hastings field

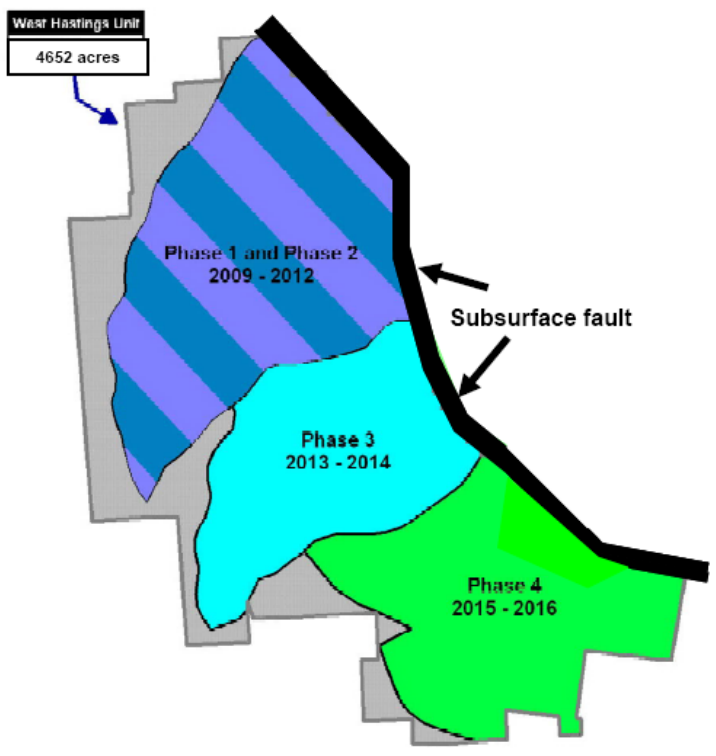

To supplement this naturally occurring $\mathrm{CO}_{2}$ supply, Denbury will utilize anthropogenic $\mathrm{CO}_{2}\left(\mathrm{CO}_{2}-\mathrm{A}\right)$ supplies to meet its rising $\mathrm{CO}_{2}$ requirements. It is anticipated that $\mathrm{CO}_{2}-\mathrm{A}$ will be available for development of blocks $B$ \& $C$ at West Hastings beginning in late 2013 , therefore a commercial preliminary design has been made and estimates of the $\mathrm{CO}_{2}$ storage capacity for the reservoir determined. Information gained from actual injection into fault block $A$ will be utilized to finalize the fault block $B$ and $C$ design during 2011and 2012; however, this injection will not dramatically impact the pore volume available for $\mathrm{CO}_{2}$ storage.

\section{Injectivity}

The injectivity of $\mathrm{CO}_{2}$ can be estimated from current water injection rates on existing Frio injectors. Water injection into the Frio of $\sim 180,000$ BWPD is being accomplished with 20 wells, an average of 9000 BWPD per well. Based on a $\mathrm{CO}_{2}$ formation volume factor of 2 $\mathrm{MCF} / \mathrm{bbl}$, this would equate to $18 \mathrm{MMCFD}$ ( -947 metric tons per day or 0.345 million metric tons/year ) $\mathrm{CO}_{2}$ per well. This rate is also consistent with the maximum erosional velocity limit of $\mathrm{CO}_{2}$ down 2-7/8" tubing, thus establishing a target injection per injector. The seven planned injection wells during the initial pattern development for blocks $B$ and $\mathrm{C}$ will therefore demonstrate that the formation can accept the planned $\mathrm{CO}_{2}-\mathrm{A}$. Insuring high injection rates into each pattern maximizes the rate at which oil is recovered, therefore improving project economics.

\section{Storage Capacity}

The storage capacity for reservoirs to be flooded in fault blocks $B$ and $C$ is shown in Table 4. A simple estimate can be made by assuming the volume of original oil-in-place can be replaced on a volume per volume basis by $\mathrm{CO}_{2}$, as done in the NATCARB atlas. The 237 million barrels oil produced occupied 284 million reservoir barrels (1.2 RB/STB) and based upon $2 \mathrm{MCF} \mathrm{CO} 2$ per reservoir barrel at 160 degrees $\mathrm{F}$ and 3000 psi, the $\mathrm{CO}_{2}$ volume to completely displace the original hydrocarbon pore volume will be 568 BCF (31 million metric tons). Inefficiencies in aerial and vertical sweep efficiency and relative 
permeability to $\mathrm{CO}_{2}$ because of remaining oil will reduce this number, dissolution of $\mathrm{CO}_{2}$ into brine and sequestration in non-productive intervals will increase this number. Because the reservoir is complex both stratigraphically, with lateral changes in sandbody properties typical of fluvial-deltaic systems, and structurally, because of cross faulting, significant uncertainty remains in exactly how the $\mathrm{CO}_{2}$ will spread from injection wells. Significant monitoring effort will be provided in both the commercial and research program to track the $\mathrm{CO}_{2}$ distribution aerially and stratigraphically to reduce this uncertainty (flood conformance). Improving quantification of the storage via monitoring is one of the goals of this project.

The West Hastings Development team recently cored a well in fault block A (WHU-3706) to determine reservoir properties for the ten major sands of the upper and lower Frio reservoirs. Plugs have been cut from the core and measurements of permeability are reported in Table 5. Additional tests will also be performed to determine connate water and residual oil saturation endpoints on approximately 5 plugs, along with oil/water and gas/oil relative permeability curves. This information will be used to guide in the selection of perforated intervals and to better understand the vertical sweep efficiency expected during the $\mathrm{CO}_{2}$ flooding process. Good water drive during production indicates that pressure increase during injection will not limit injection rates, in contrast it is expected that water injection prior to and down-dip of $\mathrm{CO}_{2}$ injection will be required to augment $\mathrm{CO}_{2}$ so that injection pressure can be raised from 2200 psi to 3100 psi desired for EOR. 
Table 4. Field Storage Capacity (Fault block B and C) based on volume-for volume replacement of original oil-in-place by $\mathrm{CO}_{2}$.

\begin{tabular}{|c|c|c|c|c|c|c|c|c|c|}
\hline \multirow[t]{7}{*}{ Upper Frio } & Sand & $\begin{array}{c}\text { Area } \\
\text { (acres) }\end{array}$ & $\begin{array}{c}\text { Thickness } \\
\text { (feet) }\end{array}$ & $\begin{array}{c}\text { Net-to-Gross } \\
\text { (decimal) }\end{array}$ & $\begin{array}{c}\text { Porosity } \\
\text { (decimal) }\end{array}$ & $\begin{array}{c}\text { Swi } \\
\text { (decimal) }\end{array}$ & $\begin{array}{c}\text { Boi } \\
\text { (RB/STB) }\end{array}$ & $\begin{array}{c}\text { OOIP } \\
\text { (bbls) }\end{array}$ & $\begin{array}{l}\text { CO2 Capacity } \\
\text { (MMCF) }\end{array}$ \\
\hline & A1 & 700 & 20 & 0.61 & 0.3 & 0.8 & 1.2 & $13,350,940$ & 32,042 \\
\hline & A2 & 675 & 30 & 0.61 & 0.3 & 0.8 & 1.2 & $19,311,181$ & 46,347 \\
\hline & A3 & 650 & 50 & 0.61 & 0.3 & 0.8 & 1.2 & $30,993,253$ & 74,384 \\
\hline & A4 & 625 & 40 & 0.61 & 0.3 & 0.8 & 1.2 & $23,840,964$ & 57,218 \\
\hline & A5 & 600 & 20 & 0.61 & 0.3 & 0.8 & 1.2 & $11,443,663$ & 27,465 \\
\hline & A - Total & & 160 & & & & & $98,940,000$ & 237,456 \\
\hline \multirow[t]{34}{*}{ Lower Frio } & Sand & $\begin{array}{l}\text { Acres } \\
\text { (acres) }\end{array}$ & $\begin{array}{c}\text { Thickness } \\
\text { (feet) }\end{array}$ & $\begin{array}{l}\text { Net-to-Gross } \\
\text { (decimal) }\end{array}$ & $\begin{array}{l}\text { Porosity } \\
\text { (decimal) }\end{array}$ & $\begin{array}{c}\text { Swi } \\
\text { (decimal) }\end{array}$ & $\begin{array}{c}\text { Boi } \\
\text { (RB/STB) }\end{array}$ & $\begin{array}{l}\text { OOIP } \\
\text { (bbls) }\end{array}$ & $\begin{array}{l}\text { CO2 Capacity } \\
\text { (MMCF) }\end{array}$ \\
\hline & B1 & 360 & 5 & 0.59 & 0.3 & 0.8 & 1.2 & $1,642,128$ & 3,941 \\
\hline & B2 & 360 & 30 & 0.59 & 0.3 & 0.8 & 1.2 & $9,852,768$ & 23,647 \\
\hline & B3 & 360 & 5 & 0.59 & 0.3 & 0.8 & 1.2 & $1,642,128$ & 3,941 \\
\hline & B - Total & & & & & & & $13,137,024$ & 31,529 \\
\hline & $\mathrm{C} 1$ & 300 & 5 & 0.87 & 0.3 & 0.8 & 1.2 & $2,016,919$ & 4,841 \\
\hline & C2 & 300 & 20 & 0.87 & 0.3 & 0.8 & 1.2 & $8,067,675$ & 19,362 \\
\hline & C3 & 300 & 20 & 0.87 & 0.3 & 0.8 & 1.2 & $8,067,675$ & 19,362 \\
\hline & C - Total & & & & & & & $18,152,269$ & 43,565 \\
\hline & D1 & 250 & 20 & 0.87 & 0.3 & 0.8 & 1.2 & $6,723,063$ & 16,135 \\
\hline & D2 & 250 & 20 & 0.87 & 0.3 & 0.8 & 1.2 & $6,723,063$ & 16,135 \\
\hline & D3 & 250 & 20 & 0.87 & 0.3 & 0.8 & 1.2 & $6,723,063$ & 16,135 \\
\hline & D4 & 250 & 20 & 0.87 & 0.3 & 0.8 & 1.2 & $6,723,063$ & 16,135 \\
\hline & D - Total & & & & & & & $26,892,251$ & 64,541 \\
\hline & E1 & 200 & 25 & 1.00 & 0.3 & 0.8 & 1.2 & $7,758,000$ & 18,619 \\
\hline & E2 & 200 & 25 & 1.00 & 0.3 & 0.8 & 1.2 & $7,758,000$ & 18,619 \\
\hline & E - Total & & & & & & & $15,516,000$ & 37,238 \\
\hline & F1 & 175 & 30 & 1.00 & 0.3 & 0.8 & 1.2 & $8,145,900$ & 19,550 \\
\hline & $\mathrm{F} 2$ & 175 & 35 & 1.00 & 0.3 & 0.8 & 1.2 & $9,503,550$ & 22,809 \\
\hline & F3 & 175 & 30 & 1.00 & 0.3 & 0.8 & 1.2 & $8,145,900$ & 19,550 \\
\hline & F4 & 175 & 11 & 1.00 & 0.3 & 0.8 & 1.2 & $3,095,442$ & 7,429 \\
\hline & F - Total & & & & & & & $28,890,792$ & 69,338 \\
\hline & G1 & 150 & 30 & 0.92 & 0.3 & 0.8 & 1.2 & $6,389,545$ & 15,335 \\
\hline & G2 & 150 & 20 & 0.92 & 0.3 & 0.8 & 1.2 & $4,259,696$ & 10,223 \\
\hline & G3 & 150 & 30 & 0.92 & 0.3 & 0.8 & 1.2 & $6,389,545$ & 15,335 \\
\hline & G4 & 150 & 10 & 0.92 & 0.3 & 0.8 & 1.2 & $2,129,848$ & 5,112 \\
\hline & G - Total & & & & & & & $19,168,634$ & 46,005 \\
\hline & $\mathrm{H} 1$ & 92 & 40 & 0.93 & 0.3 & 0.8 & 1.2 & $5,283,563$ & 12,681 \\
\hline & $\mathrm{H} 2$ & 92 & 15 & 0.93 & 0.3 & 0.8 & 1.2 & $1,981,336$ & 4,755 \\
\hline & $\mathrm{H} 3$ & 92 & 15 & 0.93 & 0.3 & 0.8 & 1.2 & $1,981,336$ & 4,755 \\
\hline & $\mathrm{H} 4$ & 92 & 50 & 0.93 & 0.3 & 0.8 & 1.2 & $6,604,454$ & 15,851 \\
\hline & H - Total & & & & & & & $15,850,689$ & 38,042 \\
\hline & Total & & & & & & & $137,607,659$ & 330,258 \\
\hline & Grand T & otal & & & & & & $236,547,659$ & 567,714 \\
\hline
\end{tabular}


Table 5. Results of core-based permeability form fault block $A$.

\begin{tabular}{|l|c|l|c|}
\hline Sand & $\begin{array}{c}\text { Horizontal } \\
\text { Permeability } \\
\text { (md) }\end{array}$ & Sand & $\begin{array}{c}\text { Horizontal } \\
\text { Permeability } \\
\text { (md) }\end{array}$ \\
\hline A1 & 238 & D1 & 812 \\
\hline A2 & 199 & D2 & 718 \\
\hline A3 & 1282 & E1 & 60 \\
\hline A4 & 950 & E2 & 665 \\
\hline A4-L & 1363 & F1 & 1160 \\
\hline A5 & 1240 & F2 & 272 \\
\hline A6 & 7 & F3 & 317 \\
\hline B1 & 513 & F4 & 8 \\
\hline C2 & 515 & G1 & 162 \\
\hline C3 & 304 & G2 & 108 \\
\hline & & G3 & 117 \\
\hline & & G4 & 244 \\
\hline
\end{tabular}

In general, the Frio sands of West Hastings Field are typical of most sandstones along the Texas and Louisiana Gulf Coast, where porosities are in the $28-32 \%$ range and permeabilities are high, in the 200-2000 md range. With initial oil saturation of approximately $80 \%$, this suggests high storage capacity for the reservoir rock. The West Hastings Frio reservoir is an excellent reservoir for $\mathrm{CO}_{2} \mathrm{EOR}$ recovery as well as $\mathrm{CO}_{2}$ storage. High primary (water drive) recoveries indicate that the aerial and vertical sweep efficiencies should be excellent.

\section{Well distribution}

An inventory of the distribution of wells in fault blocks $B$ and $C$ shows 72 active wells, 113 inactive but accessible wells, 9 temporarily abandoned wells, and 110 plugged and abandoned (P\&A) wells. Prior to beginning the flood, Denbury will expend significant effort as part of the commercial project (non-federal funds) reviewing well data and remediating wells as required to determine that wells are ready for pressure increase associated with injection. Denbury preliminarily plans to reenter selected wells and develop inverted 9- spot patterns(one injector surrounded by 9 producers). Initial plans are for seven (7) patterns to be developed in 2013 and seven (7) more in 2014. The pattern design selected for fault blocks $B$ and $C$ requires 14 CO2 injectors and 61 producers, shown in figure 5. Numerous unused wells are therefore available for conversion into monitoring wells, where cost effective. In most cases the placement of cement is not sufficient to provide certainty of zonal isolation for wells to be completed in the AZMI. 
Figure 5. Upper Frio patterns in fault blocks B and C.

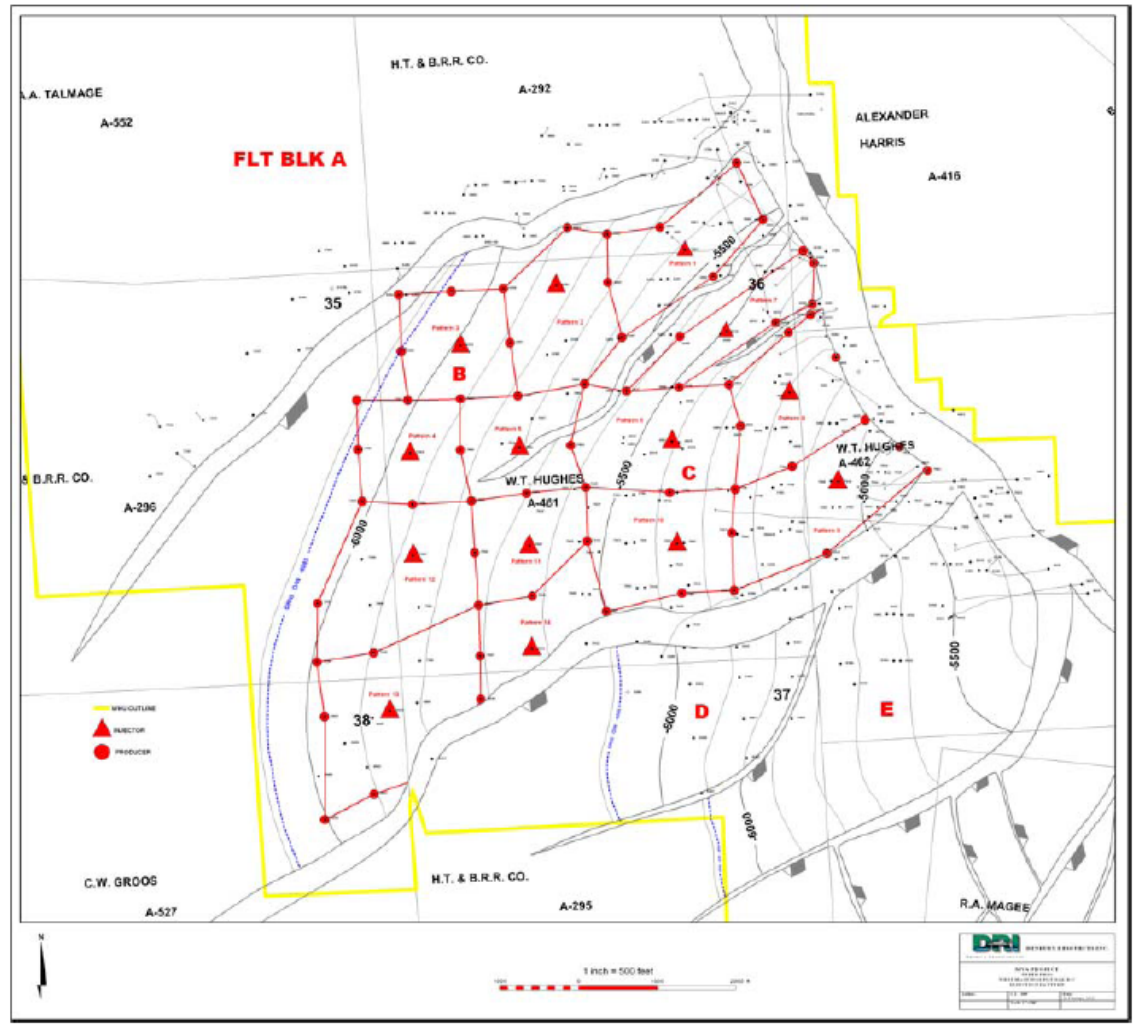

As part of the field development plan, the monthly $\mathrm{CO}_{2}$ purchase and recycle volumes were forecasted (Figure 6) using dimensionless curves obtained from an analogous field and verified by commercial modeling work performed for fault block $A$. If the anthropogenic $\mathrm{CO}_{2}$ is not ready by July 2013, CO2 from Denbury's Jackson Dome will be utilized. Peak purchases will be around 200 MMCFPD by November 2015. A total of 145 BCF (or 7.6 million metric tons) will be injected over the 3 year period. 
Figure 6. Estimated $\mathrm{CO} 2$ purchase and recycle volumes

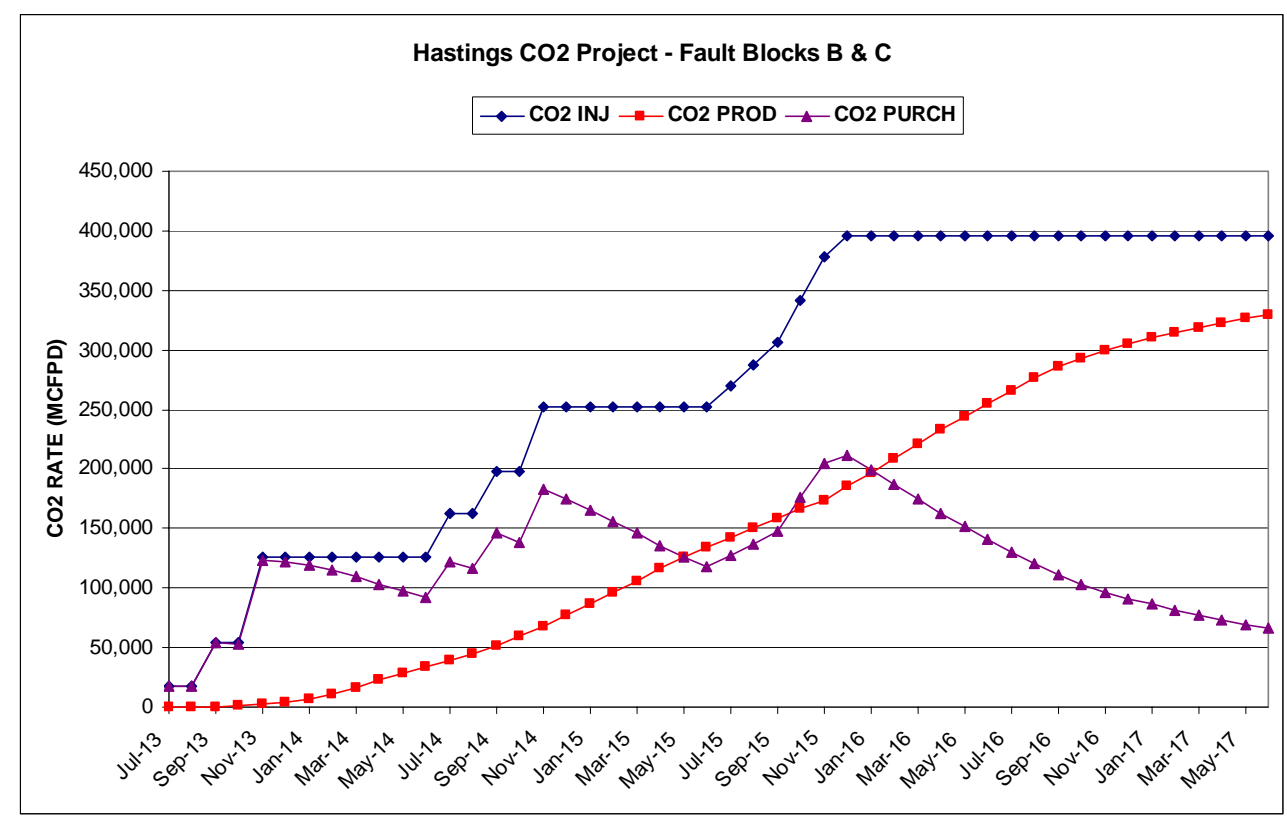

\section{Initial Risk Assessment linked to monitoring plans}

Over the past 30 years EOR projects have been conducted in the US with essentially no adverse environmental effects. Injection into known traps with well known reservoir properties greatly reduces uncertainties and resulting risk. Active management of pressure via production and operator oversight to optimize the flood also are large riskreduction measures. $\mathrm{CO}_{2}$ injected as part of EOR projects is not released to the atmosphere except in instances of equipment upsets or well upsets. Based on review of the data available at this time, there remain areas of uncertainty. For the purposes of this plan, BEG consider the following possible elements of future MVA expectations that might differ from or exceed the expectations of current Class II and commercial best practices:

(1) Document through characterization the geologic conditions that are expected to retain injected $\mathrm{CO}_{2}$ for periods long enough to benefit the atmosphere. The standards desired for sequestration are not codified, however, the IPCC target that a well selected site should retain $99 \% \mathrm{CO}_{2}$ in the reservoir over 1000 years meets or exceeds DOE's expectations. The atmospheric benefit is not a requirement of the proposed rules of the Texas Railroad Commission.

(2) Execute a formal assessment of areas of uncertainty through a process such as Risk Assessment. This write up reviews the results of the initial risk assessment.

The research MVA program will focus on areas of uncertainty in retention of fluids in the injection zone. As this oil field has retained oil and gas for geologic time, BEG considers that it documents that the natural seal is adequate to support a significant $\mathrm{CO}_{2}$ column with migration only at diffusion rates. Risk Assessment and experience indicates that the most probable migration paths are (1) non-sealing well completions because of 
undetected construction flaws or damage; (2) unexpected vertical migration up the main fault when reservoir pressure exceeds original pressure, and (3) off-structure or out of compartment migration of $\mathrm{CO}_{2}$ or brine as a result of elevated pressure into areas not controlled as part of the flood. An MVA program is outlined for each of these risk areas and is linked to a mitigation or management process that will document that the $\mathrm{CO}_{2}$ injected is permanently stored.

\section{Performance of wells}

As part of Denbury's commercial operations, prior to the start of the flood, every active, inactive and plugged and abandoned well will have its mechanical status defined prior to the start of the flood. Wells deemed as unable to contain the injected $\mathrm{CO}_{2}$ in the reservoir will be remediated by Denbury prior to initiating $\mathrm{CO}_{2}$ injection.

After $\mathrm{CO}_{2}$ injection starts, both the commercial and research activities defined in the MVA program will be used to monitor the mechanical integrity of each well. The commercial activities of the MVA program include monitoring the surface pressures of injectors and producers frequently, as well as, each inactive well. Wells that have significant changes in surface pressures, will have bottom-hole pressure surveys taken. If the pressure data suggests that a well may have a mechanical integrity problem, a profile survey will be run in the well. A tracer survey and temperature log will be run in an injector. A temperature log, spinner survey and capacitance log will be run in a producer. These surveys will be run in each active well every 6 months regardless of the pressure data to confirm that there is no migration of $\mathrm{CO}_{2}$ from the reservoir via the wellbore. Surveys will be run in the inactive wells less often. However, as mentioned above, surface pressures will be monitored frequently in these wells.

Injection and production rates will also be monitored as part of commercial activities. Daily rates will be measured for each injector and test rates will be taken for each producer at least once a month. A significant change in rates may indicate a wellbore integrity issue. Logs, as defined above, will be run in a potential problem well. If a problem is identified, then the well will be remediated.

Each pattern will also have IWR's (injection to withdrawal ratios on a reservoir barrel basis) calculated monthly to help define a problem well which requires remediation. The targeted IWR for every pattern is a 1:1 ratio. If a pattern has had such a ratio of several months and the ratio suddenly changes to $2: 1$ or 3:1 for example, then one of the wells in the pattern has a mechanical integrity issue. The problem well will be identified using the commercial activities described above and remediated.

The task for the research program is to independently test the performance of wells to determine if the commercial approaches are adequate for purposes of storage. The research plan includes surveillance of all wells via monitoring for changes in pressure or chemistry in the above zone monitoring interval (AZMI), monitoring for changes in underground sources of drinking water (USDW - defined as above 1650' per the Texas Railroad Commission in the West Hastings Field), and monitoring for changes in soil gas above plugged and abandoned (P\&A) wells. 
Appendix D: Final MVA Plan And Detailed Budget

\section{Performance of faults}

Faults can serve either as conduits which focus and enhance flow or as barriers which limit flow. The major fault at West Hasting clearly falls into the later category, as large volumes of buoyant fluids (oil) have been trapped against it. This is a typical response in large throw faults of the Gulf Coast, in which ductile shale is smeared along the fault zone, providing a seal. Faults with smaller throw, such as parts of the cross-faults, may not completely seal.

Understanding and predicting the behavior of preexisting faults in settings being considered for large scale $\mathrm{CO}_{2}$ storage is critical for operational success. Undesired migration of $\mathrm{CO}_{2}$ away from the intended interval may be facilitated by permeable faults (if present). Accurate determination of fault behavior typically involves a graphical (i.e. Mohr circle) or analytical approach, both of which are faster than complex numerical (finite-difference) models, but both retain some level of simplification. However, these more simplified approaches are considered adequate for understanding the level of risk that a large injection project has with regard to fault reactivation and increased hydraulic conductivity. It has been demonstrated that fracture sets in granitic formations show preferential fluid flow for the fracture orientations that are near the critical stress in the given stress field. The critical stress is achieved for a feature with a known orientation when the shear stresses resolved on that surface exceed the stresses normal to (perpendicular to) that surface. An increase in fluid pore pressure (as with $\mathrm{CO}_{2}$ injection) can lead to reduced normal stresses and an increased likelihood for achieving critical stress conditions.

In order to adequately determine the risk of fault criticality, the magnitude and orientation of the fault within the ambient principal stress field must be known. BEG will endeavor to constrain these conditions for the field of interest during the design phase. However, the anticipated elevation of pressure (400 psi) for West Hastings field is not considered high enough to bring even a favorably oriented fault structure into criticality. Thus, the research MVA program will focus on monitoring of the fault to determine if any flow can be identified along the fault using existing well penetrations. Localized temperature and or pressure perturbations in the vicinity of the fault may be indicative of preferential fluid migration within the fault zone. The simulation of the effects of transmissive faults will need to be undertaken in order to evaluate the conditions that may lead to unintended migration.

We place emphasis on "proving the container" prior to injection to anthropogenic $\mathrm{CO}_{2}$. Because a field slated for EOR has undergone a variety of previous and preparatory activities, a number of opportunities are presented to demonstrate that storage of $\mathrm{CO}_{2}-\mathrm{A}$ will be permanent prior to the start of injection. Although the program will run only over the 2 years of demonstration funded by the project, it is our goal to increase confidence that the injected $\mathrm{CO}_{2}$ will be permanently stored (1000 year time frame). This is another advantage to proving the container, in that not only the area right around the injection wells will be assessed, but also the ultimate updip trap.

\section{Non sealing well completions}

Wells that penetrate the seal are potential weak points, especially during injection. Wells that perform adequately during extraction, when they are pressure sinks, can become 
upwardly transmissive during injection when pressure is increased. Wells that are open can be inspected via a logging program, however wells that have been plugged and abandoned (P\&A) are prohibitively expensive to reenter to inspect. The research MVA program will extend the commercial well integrity program, and test its effectiveness.

Activities that have been included in the MVA plan:

(1) Additional logging program (e.g. temperature, tracers, high end wireline tools)

(2) Above zone-pressure monitoring - ambient and introduced fluids

(3) Near-surface soil gas and groundwater monitoring.

In West Hastings, water disposal into parts of the Miocene prior to $\mathrm{CO}_{2}$ injection has elevated pressure and perturbed geochemistry. In addition, prior to $\mathrm{CO}_{2}$ injection, water injection may be done in the Frio. If data are collected with care, water flood can serve as a pre- $\mathrm{CO}_{2}$ injection proof of containment. In the short term, this elevated pressure is a barrier to upward flow. It will be interesting to assess how long this pressure barrier will be sustained with respect to long term storage goals.

Methods for assessing well integrity planned are:

1) Thermal anomalies though casing (hot fluids expelled from depth, or cold areas in shallow zones where $\mathrm{CO}_{2}$ flashes to gas), noise anomalies though casing

2) Pressure and geochemical anomalies that require perforations

3) Augmented soil gas/aquifer surveillance methods (methane, $\mathrm{CO}_{2}$, noble gases/isotopes, tracers)

\section{Up fault migration}

In a productive reservoir, faults are adequate seals with respect to the 1000 year retention standard, as accumulation even at slow rates greatly exceeds any migration. Uncertainly is produced however by injection at pressures above initial pressure. Three methods of documenting storage adequacy with respect to faults are (1) calculated, (2) measured via microseismic, (3) measured via up-fault fluid migration.

Calculated fault opening stress is based on fault geometries and considers ambient stress plus induced stress. Initial calculation shows that injection pressure planned lies well below critical pressure on the fault. However, uncertainties remain because of assumptions about the strength of the fault materials. Direct measurements are therefore desirable to document that the characterization assumptions are correct. In brittle rocks, the stress distribution along a fault may be measured by collection of microseismic data, from well bore or in some cases surface installations. However, Frio rocks are weak, and we expect that might be able to open without seismicity. We propose to directly measure indicators of fluid migration. These measurements are mostly well based, because of sensitivity and availability of idle wells, and include thermal changes, pressure changes, and fluid composition changes including tracers. The later two methods require wells be perforated and completed across a fault zone.

\section{Out of pattern migration}

In EOR, pressure gradients from injectors to producers generally control most of the flow. Production history, starting with monthly injection/withdrawal ratios (IWR) is a relatively simple method of confirming the correctness of this assumption. For the 
research program, $\mathrm{BEG}$ will collect monitoring data to determine if $\mathrm{CO}_{2}$ migrates outside the pattern to confirm the relevance of this simple method. A combination of geophysics (VSP array and gravity) will be used to map the location of the plume edge. This technique will be further validated for this site by preparing injectors ahead of schedule, and using them early in the flood as monitoring points. After assumption are validated, these wells will be used for injection into additional patterns.

\section{Monitoring activities}

Denbury will conduct current commercial practices and provide nonproprietary results to the research MVA project at no cost to the project. The results of commercial practices provide the standard for the research MVA program. Denbury will provide documentation of the commercial activities described in the Scope of Work throughout the two year MVA monitoring period.

Denbury's typical EOR operation takes $100 \%$ of the produced well stream back to the recycle facility where the oil, water and gas are separated and measured. The produced volumes are allocated to each producer based on a monthly test. A sufficient number of test sites are constructed throughout each field to test each producer at least once a month. $\mathrm{CO}_{2}$ injection is measured by meters located at each injector.

Tubing and casing pressures are measured continuously on the production and injection wells using radio transmitters which communicate back to the SCADA system. The daily $\mathrm{CO}_{2}$ injection volumes to each injector is also measured using this system, along with wellhead and upstream pressures to the choke. The wellhead and downstream pressures to the choke will also be measured on the producing wells, thus allowing for continuous monitoring of well performance. If downstream pressure builds to high levels, relief valves will be activated to allow for bleed off of line pressure.

Tracer surveys and/or temperature logs will be run be run periodically in injectors to determine where the $\mathrm{CO} 2$ is being injected. Temperature logs, spinner surveys and capacitance logs will be run in producers periodically to define from which zone(s) the production is originating from. This data will be used to update the model during the two year research monitoring period. Profile surveys in the injectors and producers are expected to be conducted a minimum of twice per year. If injection and production rates do not change significantly, it can be assumed that the profiles are not changing and the frequency of these surveys can be reduced.

Once reservoir pressure has been raised to the desired operating pressure, injection and production will be balanced so that an injection to voidage ratio of approximately $1: 1$ is maintained. As described in the "Performance of wells" section above, these calculations will be performed on a monthly basis to show whether the pattern is over or under injecting. Remedial operations such as acidizing, re-perforating and/or other repairs will be performed on wells, if required, to maintain balanced patterns.

Research based monitoring augments the commercial monitoring through an interlocked system of collection of characterization data, modeling and risk assessment. As data is obtained, revisions will be made to our monitoring techniques and reservoir model. By the end of the two year research MVA program, the performance of the container is expected to be proven, greatly increasing confidence in storage permanence. 


\section{Scope of Work}

\section{Phase 2A, Task 1- Administrative task and subcontracting}

Prior to initiation of Phase 2 activities, a number of subtasks will be completed. These are not assigned costs but past experience suggests that they may consume time.

\section{Phase 2A, Task 2- Reservoir Modeling-Initial characterization and modeling} Denbury will provide data (as in-kind cost share) refined for input into the reservoir model to be constructed by BEG. This data will be input into task 2 reservoir modeling and used to document that the flood conforms to expected plume area and pressure elevation. Letter report will include data files as improved characterization data are collected. BEG will undertake reservoir modeling using the initial available data to predict range of plume sizes and the magnitude and distribution of pressure elevation. Table 6 shows the data that will be sought and the source. Reservoir modeling for research MVA differs from commercial monitoring done by Denbury as it (1) approaches from a migration of risk perspective, to identify uncertainties in the characterization that might lead to risk of $\mathrm{CO}_{2}$ migrating from the intended injection area, such as unmapped heterogeneities in the reservoir, and (2) although oil is represented in the model as an important part of the system, predicted oil production will not be reported as such results are outside the scope of the study.

Table 6. Data for modeling and likely data source

\begin{tabular}{|l|l|}
\hline Data & Source \\
\hline $\begin{array}{l}\text { Field history including historical } \\
\text { production drive mechanism, water } \\
\text { flood, historical pressures, etc }\end{array}$ & Denbury and literature search \\
\hline Reservoir geometry / static model & BEG from task 1 \\
\hline $\begin{array}{l}\text { Initial conditions (pressures, } \\
\text { saturations, o/w contact...) }\end{array}$ & Denbury \\
\hline Boundary conditions & BEG from task 1 \\
\hline Production tests / field tests results & Denbury \\
\hline Permeability / porosity measurements & Denbury* \\
\hline Relative permeability end points & Denbury* \\
\hline $\begin{array}{l}\text { Relative permeability and capillary } \\
\text { pressure curves }\end{array}$ & Denbury* and literature \\
\hline Oil and gas composition & Denbury* \\
\hline PVT (viscosity, density) data for oil & Denbury* \\
\hline Brine composition or at least TDS & Denbury, sampling program \\
\hline Well locations & Denbury \\
\hline $\begin{array}{l}\text { Perforated intervals for injection and } \\
\text { production wells }\end{array}$ & Denbury \\
\hline $\begin{array}{l}\text { Current injection and production } \\
\text { schedule and rates }\end{array}$ & Denbury \\
\hline $\begin{array}{l}\text { Historical production/injection rates if } \\
\text { available }\end{array}$ & Files, to be allocated \\
\hline Temperature data & Denbury \\
\hline Proximity of other oil/gas fields & Denbury + literature search \\
\hline
\end{tabular}


${ }^{*}$ Commercial proprietary non-funded data utilized to refine fluid flow and pressure modeling may be withheld from public information.

. BEG, in consultation with Denbury, will prepare a formal report describing model assumptions and outputs, as well as uncertainties that should be considered in a monitoring program. Commercial proprietary data used for input in the model may be withheld by Denbury from the report.

Phase 2A, Task 3- Characterization and geomechanical description of fault(s) BEG will undertake compilation of additional characterization data and further model the effect of a range of possible stress changes on faults, with focus on the main sealing fault at the east edge of the field. To the extent legally available, Denbury will provide data and review the results as in-kind cost share. BEG will prepare a letter report, which will predict conditions at which critical stress on fault will occur and recommend improvements to the fault monitoring plan.

\section{Phase 2A, Task 4- Soil Gas-Feasibility test of surveillance of P\&A wells}

BEG will undertake an initial assessment of soil gas conditions near representative P\&A wells, in consultation with Denbury, to consider complexities that should be considered for soil gas assessment to reduce uncertainties about well integrity in P\&A wells. BEG will also include learning from other soil gas tests now underway, for example work at Cranfield, by Denbury at Oyster Bayou, and international projects. This activity will occur after this part of the project has received a CX or under a NEPA waiver. BEG will prepare a letter report recommending future monitoring strategies.

\section{Phase 2A, Task 5- Groundwater monitoring-Feasibility test of surveillance of P\&A wells BEG will sample available wells and review Texas Water Development Board historic records to obtain information about the range of water chemistries and how to best test for rock- $\mathrm{CO}_{2}$-water interaction in the aquifer should unintended $\mathrm{CO}_{2}$ migration occur. It will also include learning from other projects underway at BEG and elsewhere to identify criteria that may signal migration. Denbury will review with regard to placement of monitoring wells for next stage of study. Field work will occur after CX or NEPA waiver is obtained. BEG will prepare a letter report recommending future monitoring strategies.}

\section{Phase 2A, Task 6-AZMI-Establish current pressure profile via Repeat Formation Test (RFT) on new drill wells}

The pressure environment at West Hastings has been highly perturbed by salt water disposal, oil and brine production, and fresh water production. This test plan will be used to characterize the pressure field and select above zone monitoring interval (AZMI). Denbury will design the drilling program to collect good quality pressure data and will discuss the plan and results with BEG. Wells will then be completed by Denbury as AZMI wells in task 16. BEG expects the target for completion is the Miocene, provided that pressure is stable. The Miocene is currently significantly above original reservoir pressure since it has been used for the disposal of the water produced from the Frio reservoirs. Workovers were costed out, because remediating the lack of cement behind casing was more expensive than new drills. This activity will occur after CX or NEPA waiver is received. Denbury will prepare a report with as-build construction and RFT results.

\section{Phase 2A, Task 7- Logging-Feasibility test of surveillance of idle wells and fault}


Sandia will subcontract and guide development of a new tool for active temperature stimulation of the reservoir to identify fluid changes and fluid flow. Zones with permeability recover faster from a thermal pulse, and it is hoped that this tool will provide permeability information relevant to migration on faults and fluid changes in AZMI though casing. Denbury will provide initial assess points for testing this tool in up to three wells that are in operation prior to the B and C flood. Novel tool development is seen as an important part of this project. Sandia will prepare a letter report with as-built tool design and operation, test results and recommendation for further use.

\section{Phase 2A, Task 8- Decision Point, Risk Assessment \& Updated MVA plan and cost distribution \\ BEG, in consultation with Denbury, will update the risk assessment and research MVA plan and cost distribution based on the results of previous data collection efforts, and will make adjustments to the research MVA program to supplement commercial operations. BEG will prepare a formal report containing phase 2B recommendations.}

\section{Phase 2B, Task 9- Commercial Flood Monitoring - Well Review and Remediation} Denbury will define the mechanical status of every wellbore within the possible plume area of the injected $\mathrm{CO}_{2}$. Wells with mechanical problems, which won't allow isolation of the $\mathrm{CO}_{2}$ within the targeted reservoir being flooded, will be re-plugged or remediated prior to the start of injection. This work will be done as part of the commercial field development project, at no cost to the research MVA project. Denbury will prepare a letter report of well status showing compliance with RRC regulations.

\section{Phase 2B, Task 10- Logging-Baseline Surveillance of idle wells and fault}

Sandia will conduct a survey beyond that conducted by Denbury in task 9 using an array of tools to critically evaluate condition of wells, especially with regard to potential for natural or anthropogenic fluid migration behind casing. This data will provide a baseline to show any changes that occur as the field is flooded. Sandia, in conjunction with Denbury will select, a sample of 20 representative wells that can be accessed. Many wells penetrate the major fault and can be used to assess if any change in fluids or fluid movement from injection is occurring in this zone. Sandia will prepare a letter report with methods and results.

\section{Phase 2B, Task 11- Soil Gas-Site \& Borehole preparation for surveillance of P\&A wells}

BEG, in consultation with Denbury, will select 20 P\&A wells to assess using the methods recommended in Phase 2A, Task 4 and develop characterization data such as samples and access tubes, shallow wells or other infrastructure needed. BEG will prepare a letter report with as built construction and field notes.

\section{Phase 2B, Task 12- Soil Gas-Baseline surveillance of P\&A wells}

BEG will conduct, in consultation with Denbury, data collection on soil gas sites that were developed in Task 11. Results will be critically assessed to provide information on the value of this approach to documenting well integrity. BEG will prepare a letter report of methods and data table.

\section{Phase 2B, Task 13- Ground Water Monitoring -Well preparation}

Denbury and BEG will select four wells that will be completed in the USDW interval and monitored for $\mathrm{CO}_{2}$ migration following the methods developed in Phase 2A, Task 5 . Denbury plans to recomplete existing wells. Thirteen wells with suitable cemented-in 
surface casing below $1650 \mathrm{ft}$ have been identified by the Denbury Field team. BEG will prepare a letter report showing as-built construction and field notes.

\section{Phase 2B, Task 14- Ground Water Monitoring -Baseline surveillance}

BEG will purchase a pump, sample and than analyze the groundwater wells installed in Task 13. Four sets of samples will be collected to establish a baseline before $\mathrm{CO}_{2}$ injection starts. BEG will prepare a letter report including methods, field notes and data table.

\section{Phase 2B, Task 15- Reservoir Modeling-Upgraded}

BEG will incorporate data from Tasks $2 \mathrm{~A}$ to predict range of plume sizes and magnitude and areas of pressure elevation and provide to Denbury for review. This result will be used to modify and adjust the risk assessment and monitoring strategy as needed. BEG will prepare a letter report showing changes in model parameters, revised predictions on area of $\mathrm{CO}_{2}$ plume and distribution and magnitude of pressure change.

\section{Phase 2B, Task 16- AZMI-Well Completions}

Denbury will complete the AZMI wells from Phase 2A, Task 6 in the above zone with screens that will protect the poorly consolidated Miocene from sanding over the perforations, and install any constructed-in temperature monitoring equipment. Denbury will prepare a letter report containing field notes and as-built construction.

\section{Phase 2B, Task 17- AZMI-Instrument Monitoring Wells}

Sandia will install and maintain pressure gauges on monitoring wells completed in Task 16 in AZMI and fault zones. Completions are designed to be simple, without tubing and packer, and pressure gage hung in the water column. Pressure data will be available via cell phone or data logger. Sandia will prepare a letter report containing field notes.

Phase 2B, Task 18- AZMI- Hydrologic testing and Baseline geochemical sampling Sandia, in consultation with Denbury, will conduct pressure interference test to show hydrologic communication and the area over which the AZMI provides evidence of containment. BEG will collect and analyze pre injection fluids and gases for geochemical samples. Sandia and BEG will prepare a letter report providing methods and field notes.

Phase 2B, Task 19- VSP-Baseline

Denbury, in coordination BEG, will plan and conduct a baseline VSP survey as an augmented measure of flood conformance. Each proposed 4D-VSP will illuminate an area approximately 1 sqmi. We should plan for 5 3DVSP's in fault block B/C to image $\mathrm{CO}_{2}$ fillup through the reservoir and above/below the reservoir and along faults. With high resolution $3 \mathrm{D}-\mathrm{VSP}$ seismic data we hope to resolve sand units as thin as $10 \mathrm{ft}$. When these 3D-VSP's are repeated we will map where the reservoir changes based on density and pressure changes in the seismic response. Costs for surveys include the surveys, well operations, permitting for seismic sourcing on the surface, and processing. The seismic will require a baseline plus 4 repeats in Phase $2 \mathrm{C}$ and done in coordination with the gravity logging. Denbury will prepare a letter report providing the details of the field deployment.

\section{Phase 2B, Task 20- Gravity-Baseline}

Denbury may conduct gravity survey as an augmented measure of conformance. John Ferguson at UT Dallas was successful in monitoring water migration during the Delhi Field water flood and is studying a model for Hastings. The density variance between 
$\mathrm{CO}_{2}$ and reservoir fluids in Hastings should be more significant than the density variance of the injected water and oil in the reservoir during the Delhi water flood, so gravity monitoring of the Hastings $\mathrm{CO}_{2}$ flood is expected to be successful in defining the location of the $\mathrm{CO}_{2}$ plume. Gravity logging will quantify $\mathrm{CO}_{2}$ saturations in the boreholes where porosity is well constrained. Denbury may monitor above/below the reservoir and through the reservoir. The baseline is planned to be followed by 4 repeats in Phase $2 \mathrm{C}$. Denbury will prepare a letter report documenting field notes and data tables.

\section{Phase 2B, Task 21- Measure Out-Of-Pattern Migration (Completion of downdip wells)}

As the first year of the flood is being developed, two wells outside that phase will be completed by Denbury and used to monitor the possible migration of the $\mathrm{CO}_{2}$ and elevation of pressure outside the completed patterns. In the case of Hastings blocks $B \& C$, the phases of development will be from the top of structure downdip. These wells will become active wells in future phases of development. Denbury will prepare a letter report including well completion diagrams and daily records of well-head pressure.

\section{Phase 2B, Task 22- PFT partitioning in complex fluids}

Praxair PFT's are a tool that may used to complement other MVA techniques to yield information about fluid flow. Because of very low detection limits, PFT's in addition can offer unique techniques to analyze for $\mathrm{CO}_{2}$ that cannot be accurately accounted for using the conventional technologies, for example to detect any possible migration along $P \& A$ or idle wells. Recent experience with a PFT added to $\mathrm{CO}_{2}$ injected into a coal seam in Virginia indicated that the PFT's can be conservative even in presence of organics. In fact, due to the sensitivity of the tracer measurement, it is detectable well in advance of a detectable change in the $\mathrm{CO}_{2}$. The high resolution that tracers offer can allow time for a mitigation plan to be implemented before the minor amounts of $\mathrm{CO}_{2}$ becomes a problem. However, we do not have a good lab-based understanding of where the PFT will partition in a brine-oil- $\mathrm{CO}_{2}$-methane mixture. This information will make PFT a more valuable MVA technique.

At BEG, reaction of PFT with brines and minerals in $\mathrm{CO}_{2}$ injection through brinesaturated rocks under reservoir temperature and pressure condition will be experimentally simulated. A bench-top reaction system will be used for scanning of reaction rates and how PTF concentration change is affected by variations in parameters such as $\mathrm{CO}_{2}$ pressure, mineralogy, water/mineral ratio, oil-saturation, salinity, $\mathrm{pH}$, and temperature. A flow-through column reaction system will be used for monitoring PFT concentration change in the transport through a certain brine/rock environment. In general, PFT concentration, in-situ water chemistry, and in-situ acidity will be monitored and investigated.

The existing high temperature and high pressure bench-top $\mathrm{CO}_{2} /$ brine/rock simulation system is available for our scanning test. We will purchase a continuous flow-through column reaction system for monitoring PFT concentration change in the transport under reservoir temperature and pressure condition. BEG will prepare a formal report documenting methods, results and recommendations for use of PFT for the research MVA project. BEG will provide a copy of such report to Denbury. After reviewing the report, Denbury will determine whether tracer testing will be used in the research MVA project.

\section{Phase 2B, Task 23- Decision Point, Risk Assessment \& Updated MVA plan and cost distribution}


BEG, in consultation with Denbury, will update the risk assessment and MVA plan and cost distribution in consideration of the results of previous data collection efforts, and will make adjustments to the research MVA program to supplement Denbury's commercial operations. BEG will prepare a formal report containing Phase $2 \mathrm{C}$ recommendations.

\section{Phase 2C, Task 24- Commercial Flood Monitoring-Injection and Production Volumes \\ Denbury will report to the research MVA project the results of commercial flood} monitoring quantifying all injected and produced fluids (including recycle), wellhead pressure, and intermittent injection profiles. This commercial monitoring program will account for purchase and recycle volumes giving the volume of $\mathrm{CO}_{2}$ in the reservoir and the amount methane produced and recycled with the $\mathrm{CO}_{2}$.

This work will be done as part of the commercial project but is the most essential monitoring data. BEG will prepare a monthly report providing details on the distribution of the stored $\mathrm{CO}_{2}$.

\section{Phase 2C, Task 25- Commercial Flood Monitoring-Best Practice Mitigation} Denbury will provide to the research MVA project information about mitigation for poor well performance to document how conformance is attained commercially. For example if a well will not accept the planned injection rate at field pressure, Denbury may acidize, reperforate, or inject at a higher rate in other parts of pattern. This work will be done as part of the commercial field development project.

\section{Phase 2C, Task 26- Commercial Flood Monitoring-Pressure Maintenance Denbury will perform normal well surveillance including monitoring casing pressures in both producers and injectors. Denbury will use remediation procedures to repair wells with compromised integrity. Denbury will provide the results of this work done as part of the commercial project.}

\section{Phase 2C, Task, 27- Commercial Flood Monitoring-IWR Calculation}

Denbury will calculate material balance from data in Task 24 for each pattern on a monthly basis to define changes in reservoir performance. Significant changes in IWR identify potential problem wells within the pattern (i.e. mechanical problems with injectors or inactive wells which are causing the loss of $\mathrm{CO}_{2}$ out of the pattern, or a mechanical problem with the producer(s) within that pattern). The problem wells will be identified and repaired (re-plugged or remediated). This work will be done as part of the commercial field development project.

Phase 2C, Task 28- Logging-Time lapse surveillance of idle wells and fault Sandia will conduct a logging and surveillance program on 20 idle wells for which baseline data was collected in Phase 2B, Task 10. This data will be compared to the baseline to show any changes that occur as the field is flooded. Sandia will prepare a letter report with methods and results.

\section{Phase 2C, Task 29- Soil Gas Time lapse surveillance of P\&A wells}

BEG will collect time lapse data over two years for soil gas sites in which baseline data was collected in Phase 2B, Task 12. Results will be critically assessed to provide information on the value of this approach to documenting well integrity. BEG will prepae a letter report containing data tables and field notes.

\section{Phase 2C, Task 30- Groundwater Monitoring-Time lapse surveillance}


Appendix D: Final MVA Plan And Detailed Budget

BEG will sample and then analyze the groundwater wells for which baseline was collected in Phase 2B, Task 14. Samples will be collected to look for changes as $\mathrm{CO}_{2}$ injection starts. BEG will prepare a letter report containing data tables and field notes.

\section{Phase 2C, Task 31- PFT-Place in injection stream}

If tracer testing is approved by Denbury in task 22, Praxair will travel to the field site and place PFT via a small, high pressure pump in the injection stream of two wells. This will be done after injection is well established, so that initial $\mathrm{CO}_{2}$ breakthrough has happened in some parts of the pattern. It is proposed that the injection period will be about two weeks. Praxair will prepare, and review with Denbury prior to submission, a letter report containing-as completed tracer injection rate.

\section{Phase 2C, Task 32- PFT-Surveillance of P\&A wells}

If tracer testing is approved by Denbury in task 22, Praxair will bring their mobile lab and field technicians to test for appearance of PFT at the surface near P\&A and idle wells. This will be most conclusive prior to PFT breakthrough at producers, after which traces of PFT will be recycled to many points in the field. Six trips are budgeted over 18 months. Praxair will prepare, and review with Denbury prior to submission, a formal report describing methods, field notes, and results.

\section{Phase 2C, Task 33- VSP-Time lapse surveys}

Denbury will conduct 4 repeat VSP surveys over the two-year period following the baseline run in Phase 2B Task 19. This data will be used to show that the flood is conforming to the expected patterns, including providing data about out-of zone migration. Denbury will prepare a formal report including methods and results of surveys on annual basis.

\section{Phase 2C, Task 34- Gravity Time lapse surveys}

Denbury will conduct 4 repeat gravity surveys over the two-year period following the baseline run in Phase 2B Task 20. This data will be used to show that the flood is conforming to the expected patterns and to quantify the volume distribution. Denbury will prepare a formal report including methods and results of surveys on annual basis.

\section{Phase 2C, Task 35- Real Time BHP-Well Preparation}

Sandia will deploy bottom hole pressure gage(s) on a real time read out in one well in the injection interval(s). This type of data has proven valuable at Cranfield to assess the nature of the flood, and given the complexity at West Hastings is expected to be even more valuable. Letter report will show as-built well schematics.

\section{Phase 2C, Task 36- Real Time BHP-Sandia}

Sandia will maintain and back up data collected in the deployment described in Phase 2C Task 35. Sandia will prepare a letter report containing a data tables and field notes.

\section{Phase 2C, Task 37- Logging-Time lapse Surveillance}

Denbury will augment measures of conformance to provide data for match to the model by logging about half the injectors and producers in the fault block $B$ and $C$ patterns every half year after the flood starts. Combination temperature and tracer surveys will be run on injection wells twice per year per well. Producers will have spinner, temperature, and capacitance tools run twice a year per well, assuming a 6 month delay in start up in producing the wells, while each of the injectors would have a series of four logs run. This 
program will run on about $1 / 2$ wells and testing of additional log types is possible. Denbury will prepare a letter report containing a data tables and field notes.

Phase 2C, task 38, PFT tracers collected at wellhead in producers and AZMI and analyzed by Praxair Seeper Trace lab.

If tracer testing is approved by Denbury in task 22,BEG will provide samples from the AZMI. Praxair will provide instructions on sample quality and avoiding contamination. Praxair will prepare, and review with Denbury prior to submission, a letter report containing data tables from Praxair and field notes from sample collections.

Phase 2C, Task 39- Natural geochemical tracers-Collected at wellhead BEG will, with the assistance of Denbury, collect at wellhead fluid samples from producers that serve as augmented measures of conformance, for example evidence of dissolution and rock-water interaction. BEG will prepare a letter report containing data tables and field notes.

Phase 2C, Task 40- AZMI-Time lapse geochemical sampling \& hydrologic testing Sandia will conduct time-lapse hydrologic sampling of AZMI wells via pumping for BEG to sample to look for any geochemical evidence of out of zone migration of $\mathrm{CO}_{2}$ as part of the above -zone and fault monitoring program. BEG will conduct analysis of samples and prepare a letter report containing data table and field notes.

\section{Phase 2C, Task 41- Measure Out-Of-Pattern Migration}

In this task Denbury will report observation of the wells prepared in Task 21, including first year of fault block $B$ and $C$ flood pressure change at well heads. This should provide one year of data before beginning of flood near these wells. Denbury will prepare a letter report of pressure data and provide it to BEG for including Phase 2C Task 42 history match of well head pressure.

Phase 2C, Task 42- Reservoir Modeling-Updated

BEG will aggregate data from Phase $2 \mathrm{C}$ activities to history match plume size and pressure elevation and test if flood conformance to model expectation was achieved. This will focus on $\mathrm{CO}_{2}$ and pressure quantification, not oil production. Denbury will review the formal report prepared.

Phase 2C, Task 43- Overview and Evaluation report

BEG will prepare and Denbury will review a report of the results of this study. BEG and Denbury will determine what, if any, added value the research program added to the commercial program in terms of confidence in the long-term permanence of storage. BEG will recommend any actions that may be informative to future regulations or policies related to storage monitoring at EOR sites. This will be a formal report. 


\begin{tabular}{|c|c|c|c|c|}
\hline \multicolumn{3}{|c|}{ Proposal for Hastings - Praxair } & \multirow[b]{2}{*}{ Task Title } & \multirow[b]{2}{*}{ Component } \\
\hline Phase & Task \# & Monitoring element & & \\
\hline $2 \mathrm{~A}$ & 1 & $\begin{array}{l}\text { Adminstrative tasks \& } \\
\text { Contracting }\end{array}$ & Adminstrative tasks \& Contracting & \\
\hline $2 \mathrm{~A}$ & 2 & Flood Conformance & Resrvoir Modeling-Initial Characterization and Modeling & $\begin{array}{l}\text { Initial reservoir modeling - available data to predict range of plume sizes and } \\
\text { magnitude and areas of pressure elevation }\end{array}$ \\
\hline $2 \mathrm{~A}$ & 3 & Fault Monitoring & $\begin{array}{l}\text { Characterization and Geochemical Description of } \\
\text { Fault(s) }\end{array}$ & Characterization and geomechanical description of fault(s) \\
\hline $2 \mathrm{~A}$ & 4 & Well Integrity & Soil Gas-Feasibility Test of Surveillance of P\&A wells & Feasibility test of surveillance of $P \& A$ wells via soil gas \\
\hline $2 \mathrm{~A}$ & 5 & Well Integrity & $\begin{array}{l}\text { Groundwater Monitoring-Feasibility Test of Surveillance } \\
\text { of P\&A wells }\end{array}$ & Feasibility test of surveillance of $P \& A$ wells via groundwater monitoring \\
\hline $2 \mathrm{~A}$ & 6 & Above-zone monitoring & $\begin{array}{l}\text { AZMI-Establish Current Pressure Profile via Repeat } \\
\text { Formation }\end{array}$ & $\begin{array}{l}\text { Establish current pressure profile via RFT on new drills, select above zone } \\
\text { monitoring interval (AZMI) }\end{array}$ \\
\hline $2 \mathrm{~A}$ & 7 & $\begin{array}{l}\text { Well Integrity \& Fault } \\
\text { Monitoring }\end{array}$ & $\begin{array}{l}\text { Logging-Feasibility Test of Surveillance of idle wells and } \\
\text { fault }\end{array}$ & Feasibility test of surveillance of idle wells and fault via logging \\
\hline $2 \mathrm{~A}$ & 8 & $\begin{array}{l}\text { Decision Point \& Scope and } \\
\text { Budget Update }\end{array}$ & $\begin{array}{l}\text { Decision Point, Risk Assessment \& Updated MVA plan } \\
\text { and cost distribution }\end{array}$ & Risk Assessment \& Updated MVA plan and cost distribution \\
\hline $2 \mathrm{~B}$ & 9 & Well integrity & & Commercial well review and remediation as needed prior to flood \\
\hline $2 \mathrm{~B}$ & 10 & Well integrity/fault monitoring & & Baseline surveillance of idle wells and fault via logging \\
\hline $2 \mathrm{~B}$ & 11 & Well integrity & & Site and borehole preparation for surveillance of $P \& A$ wells via soil gas \\
\hline $2 \mathrm{~B}$ & 12 & Well integrity & & Baseline surveillance of P\&A wells via soil gas \\
\hline $2 \mathrm{~B}$ & 13 & Well integrity & & Ground water well preparation \\
\hline $2 \mathrm{~B}$ & 14 & Well integrity & & Baseline surveillance via groundwater monitoring \\
\hline $2 \mathrm{~B}$ & 15 & Flood conformance & & $\begin{array}{l}\text { Upgraded reservoir modeling - data from tasks } 2 \mathrm{~A} \text { to predict range of plume } \\
\text { sizes and magnitude and areas of pressure elevation }\end{array}$ \\
\hline $2 \mathrm{~B}$ & 16 & $\begin{array}{l}\text { Above -zone monitoring and } \\
\text { fault monitoring }\end{array}$ & & Complete selected wells in above zone interval(s) to create AZMI wells \\
\hline $2 \mathrm{~B}$ & 17 & $\begin{array}{l}\begin{array}{l}\text { Above -zone monitoring and } \\
\text { fault monitoring }\end{array} \\
\end{array}$ & & Instrument monitoring wells wells in AZMI \\
\hline $2 \mathrm{~B}$ & 18 & $\begin{array}{l}\text { Above -zone monitoring and } \\
\text { fault monitoring }\end{array}$ & & Baseline geochemical sampling and hydrologic testing of AZMI \\
\hline $2 \mathrm{~B}$ & 19 & Flood conformance & & Baseline VSP - augmented measure of flood conformance. \\
\hline $2 \mathrm{~B}$ & 20 & Flood conformance & & Baseline gravity- augmented measures of conformance \\
\hline $2 \mathrm{~B}$ & 21 & Flood conformance & & Measure-out of pattern migration - early completion of year 2 pattern \\
\hline $2 \mathrm{~B}$ & 22 & $\begin{array}{l}\text { Well integrity/Flood } \\
\text { Conformance }\end{array}$ & & PFT partitioning in complex fluids \\
\hline $2 \mathrm{~B}$ & 23 & $\begin{array}{l}\text { Decision point and scope and } \\
\text { budget update }\end{array}$ & & Risk Assessment and updated MVA plan and cost distribution \\
\hline $2 \mathrm{C}$ & 24 & Flood conformance & Commercial Flood Monitoring-Injection and Production & $\begin{array}{l}\text { Commercial flood monitoring- Quantifying all injected and produced fluids } \\
\text { (including recycle), daily pressure at well head, interment injection profiles }\end{array}$ \\
\hline $2 \mathrm{C}$ & 25 & Flood conformance & Commercial Flood Monitoring-Best Practice Mitigation & $\begin{array}{l}\text { Normal Denbury approach to mitigation, e.g. if a well will not take the planned } \\
\text { rate, that is acidize, reperforate, or inject at a higher rate in other parts of } \\
\text { pattern. }\end{array}$ \\
\hline $2 \mathrm{C}$ & 26 & Well integrity & Commercial Flood Monitoring-Pressure Maintenance & $\begin{array}{l}\text { Normal well surveillance (casing pressure) and remediation procedure for } \\
\text { active wells to assure wells retain fluids }\end{array}$ \\
\hline $2 \mathrm{C}$ & 27 & Well integrity & Commercial Flood Monitoring-IWR Calculation & 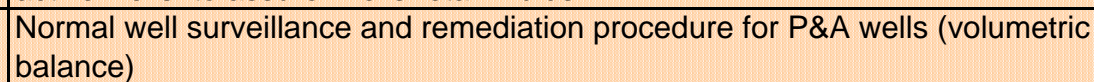 \\
\hline $2 \mathrm{C}$ & 28 & Well integrity/fault monitoring & Logging-Time lapse surveillance of idle wells and fault & Time laps surveillance of idle wells and fault via logging \\
\hline $2 \mathrm{C}$ & 29 & Well integrity & Soil G & Time laps s \\
\hline $2 \mathrm{C}$ & 30 & Well integrity & Groundwater Monitoring-Time lapse surveillance & Time laps surveillance via groundwater monitoring \\
\hline $2 \mathrm{C}$ & 31 & Well integrity & PFT -Injection & Place PFT in injection stream \\
\hline $2 \mathrm{C}$ & 32 & Flood conformance & PFT - Time lapse surveillance of P\&A wells & Surveillance of $P \& A$ wells via Seeper trace \\
\hline $2 \mathrm{C}$ & 33 & Flood conformance & VSP-Time lapse surveys & Time laps augmented measures of conformance - VSP \\
\hline $2 \mathrm{C}$ & 34 & Flood conformance & Gravity Time lapse surveys & Augmented measures of conformance-gravity \\
\hline
\end{tabular}

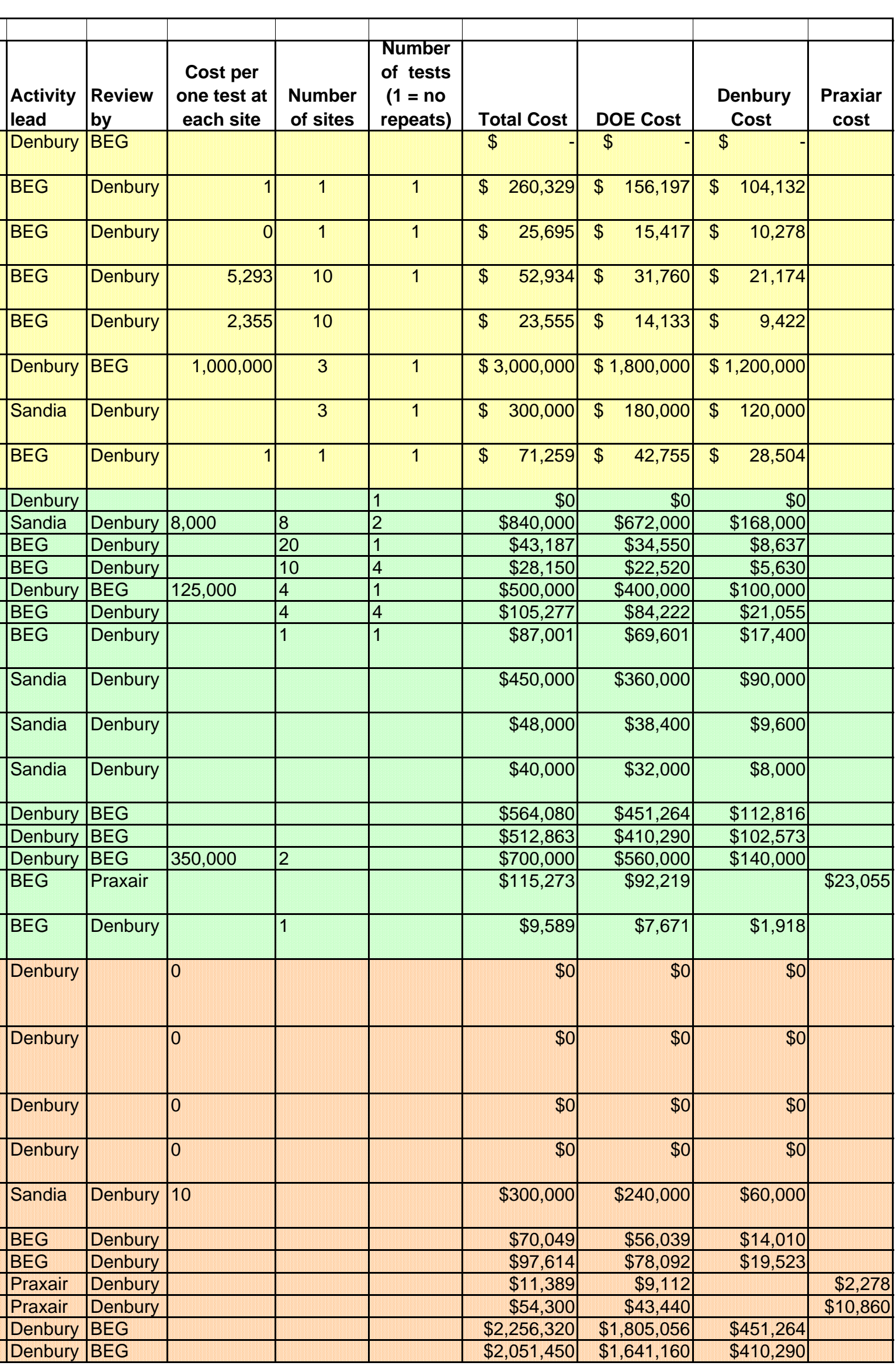
\begin{tabular}{l|l|l|l}
\hline Denbury & BEG \\
\hline Denbury & BEG \\
\hline
\end{tabular}

Page D-31 of 32 
Appendix D: Final MVA Plan And Detailed Budget

\begin{tabular}{|c|c|c|c|c|c|c|c|c|c|c|c|c|c|}
\hline Phase & Task \# & Monitoring element & Task Title & Component & $\begin{array}{l}\text { Activity } \\
\text { lead }\end{array}$ & $\begin{array}{l}\text { Review } \\
\text { by }\end{array}$ & \begin{tabular}{|c} 
Cost per \\
one test at \\
each site
\end{tabular} & $\begin{array}{c}\text { Number } \\
\text { of sites }\end{array}$ & \begin{tabular}{|c|} 
Number \\
of tests \\
$(1=$ no \\
repeats)
\end{tabular} & Total Cost & DOE Cost & $\begin{array}{c}\text { Denbury } \\
\text { Cost }\end{array}$ & $\begin{array}{c}\text { Praxiar } \\
\text { cost }\end{array}$ \\
\hline $2 \mathrm{C}$ & 35 & Flood conformance & Real Time BHP-Well Preparation & Well preparation for augmented measures of conformance - real time BHP & Sandia & Denbury & & & & $\$ 1,000,000$ & $\$ 800,000$ & $\$ 200,000$ & \\
\hline $2 \mathrm{C}$ & 36 & Flood conformance & Real Time BHP-Sandia & Augmented measures of conformance - real time BHP & Sandia & & & & & $\$ 20,000$ & $\$ 16,000$ & $\$ 4,000$ & \\
\hline $2 \mathrm{C}$ & 37 & Flood conformance & Logging-Time lapse Surveillance & Augmented measures of conformance - Increased logging program & Denbury & & 6,000 & 54 & 3 & $\$ 972,000$ & $\$ 777,600$ & $\$ 194,400$ & \\
\hline $2 \mathrm{C}$ & 38 & Flood conformance & PFT - tracers collected at wellhead & $\begin{array}{l}\text { Augmented measures of conformance PFT tracers collected at wellhead in } \\
\text { producers and AZMI and analized }\end{array}$ & Praxair & & 300 & 452 & 24 & $\$ 135,600$ & $\$ 108,480$ & & $\$ 27,120$ \\
\hline $2 \mathrm{C}$ & 39 & Flood conformance & Natural geochemical tracers-Collected at wellhead & $\begin{array}{l}\text { Augmented measures of conformance natural geochemical tracers, collected } \\
\text { at wellhead }\end{array}$ & BEG & Denbury & & & & $\$ 69,491$ & $\$ 55,593$ & $\$ 13,898$ & \\
\hline $2 \mathrm{C}$ & 40 & $\begin{array}{l}\text { Above -zone monitoring and } \\
\text { fault monitoring }\end{array}$ & $\begin{array}{l}\begin{array}{l}\text { AZMI-Time lapse geochemical sampling \& Hydrologic } \\
\text { testing }\end{array} \\
\text {. }\end{array}$ & \begin{tabular}{|l} 
Time laps Geochemical sampling and hydrologic testing of AZMI \\
\end{tabular} & Sandia & BEG & & & & $\$ 60,000$ & $\$ 48,000$ & $\$ 12,000$ & \\
\hline $2 \mathrm{C}$ & 41 & Flood conformance & Measure Out-Of-Pattern Migration & $\begin{array}{l}\text { Measure-out of pattern migration - observation of first year flood pressure } \\
\text { change in year } 2 \text { pattern }\end{array}$ & Denbury & BEG & & & & $\$ 0$ & $\$ 0$ & $\$ 0$ & \\
\hline $2 \mathrm{C}$ & 42 & Flood conformance & Reservoir Modeling-Updated & $\begin{array}{l}\text { updated reservoir modeling - data from } 2 \mathrm{C} \text { to history match plume size and } \\
\text { pressure elevation }\end{array}$ & BEG & Denbury & & & & $\$ 12,895$ & $\$ 10,316$ & $\$ 2,579$ & \\
\hline $2 \mathrm{C}$ & 43 & Overview & Overview and Evaluation Report & Evaluation Report & BEG & Denbury & & & & $\$ 8,616$ & $\$ 6,893$ & $\$ 1,723$ & \\
\hline & & & & & & & & & & $\$ 14,896,917$ & $\$ 11,170,779$ & $\$ 3,662,825$ & $\$ 63,313$ \\
\hline & & & & & & & & & race & \begin{tabular}{|r|}
$\$ 316,563$ \\
$\$ 1540354$
\end{tabular} & & & \\
\hline
\end{tabular}

